\title{
A Regulatory Analysis on Emergency Preparedness for Fuel Cycle and Other Radioactive Material Licensees
}

Final Report

$$
\text { NUREG--1140-Final }
$$

Manuscript Completed: November 1987

Date Published: January 1988

S. A. McGuire

Division of Reactor Accident Analysis Office of Nuclear Regulatory Research U.S. Nuclear Regulatory Commission Washington, DC 20555

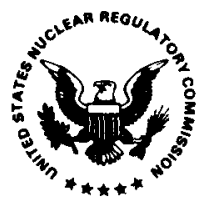




\section{DISCLAIMER}

This report was prepared as an account of work sponsored by an agency of the United States Government. Neither the United States Government nor any agency Thereof, nor any of their employees, makes any warranty, express or implied, or assumes any legal liability or responsibility for the accuracy, completeness, or usefulness of any information, apparatus, product, or process disclosed, or represents that its use would not infringe privately owned rights. Reference herein to any specific commercial product, process, or service by trade name, trademark, manufacturer, or otherwise does not necessarily constitute or imply its endorsement, recommendation, or favoring by the United States Government or any agency thereof. The views and opinions of authors expressed herein do not necessarily state or reflect those of the United States Government or any agency thereof. 


\section{DISCLAIMER}

Portions of this document may be illegible in electronic image products. Images are produced from the best available original document. 



\section{EXECUTIVE SUMMARY}

The question this Regulatory Analysis sought to answer is: Should the NRC impose additional emergency preparedness requirements on certain fuel cycle and other radioactive material licensees for dealing with accidents that might have offsite releases of radioactive material? To answer the question, we analyzed potential accidents for 15 types of fuel cycle and other radioactive material licensees.

The most potentially hazardous accident, by a large margin, was determined to be the sudden rupture of a heated multi-ton cylinder of UF 6 . Acute fatalities would be possible in the immediate vicinity of the release point. Acute permanent injuries may be possible for many hundreds of meters, and clinically observable transient effects that have no known long term consequences may be possible for distances up to a few miles. These effects would be caused by the chemical toxicity of the $U_{6}$ and the products resulting from its reaction with moisture. Accompanying radiation doses would not be of significance.

The most potentially hazardous accident due to radiation exposure was determined to be a large fire at certain facilities handling large quantities of alpha-emitting radionuclides (i.e., Po-210, Pu-238, Pu-239, Am-241, Cm-242, Cm-244) or radioiodines (I-125 and I-131). However, acute fatalities or injuries to people offsite due to accidential releases of these materials do not seem plausible. A few other radionuclides are of lesser importance $(H-3$, $\mathrm{P}-32, \mathrm{Sr}-90$, and $\mathrm{Cs}-137)$. If plutonium were to be handled at fuel cycle facilities, a fire in such a facility may also be of significance.

The only other significant accident was identified as a long-term pulsating criticality at fuel cycle facilities handling high-enriched uranium or plutonium in aqueous solutions.

Aside from fires or accidents that lead to fires, $U F_{6}$ releases, or criticality accidents, no other significant accidents were identified. Explosions were not seen to yield as large a release unless they were followed by a fire. Tank ruptures were not identified as having a potential for significant releases. Earthquakes also were not identified as leading to significant 
releases unless they were followed by a fire. Tornados might cause large release, but would disperse the material so widely that significant doses would not result.

The criterion for deciding whether an accident was significant is whether a release could cause a person outside the plant on the plume centerline to receive an effective dose equivalent of more than 1 rem, a thyroid dose of more than 5 rems, or an intake of soluble uranium exceeding $2 \mathrm{mg}$. One rem whole body or 5 rems thyroid are at the lower end of the range of dose for which the EPA says protective actions should be considered. A rough screening identified 64 licensees authorized to possess quantities of radioactive materials for which an accident release could cause doses exceeding 1 rem effective dose equivalent, 5 rems thyroid, or intake of $2 \mathrm{mg}$ of soluble uranium. However, some of these licensees do not actually possess all of the materials authorized by the license. These licensees are likely to amend their licenses to lower their possession limits rather than submit a plan. Other licensees could demonstrate that a significant release is not possible. In actuality, only about 30 plans would be submitted.

For most of these licensees the degree of hazard is small. For most such licensees maximum doses for even the most severe postulated accidents are only a few rems. The areas within which people should take protective actions are small - for most licensees much less than a square mile. At most sites these areas would contain few people. And the probability of a major release is smal1 - less than $10^{-4} / \mathrm{yr}$, for radiological releases (but higher for $\mathrm{UF}_{6}$ releases.) The probability of a major release simultaneous with highly adverse meteorology is less than $10^{-5} / \mathrm{yr}$. Thus the probability of even a single person's receiving a dose in excess of 1 -rem at most of these facilities has about the same probability as a core melt accident with containment failure at a nuclear power plant.

A further feature of major accidents at such licensed facilities is that airborne releases are likely to occur rapidly with little warning. Ruptures of UF $_{6}$ cylinders and fires would give little or no warning. Releases could start before a fire is detected or shortly thereafter. Plume travel time to nearby people is likely to be no more than a few minutes. Releases would, in a majority of cases, end within half an hour to an hour when the fire department controlled the fire. In most instances, actions taken half an hour after accident detection would be fairly ineffective. Actions taken 15 minutes after accident 
detection could on the average be expected to be roughly $50 \%$ effective. Thus protective actions would have to be taken quickly. This requires prompt actions by people in the vicinity of the site to notify nearby residents. There is not likely to be enough time for dose projections or complicated decisionmaking during the accident, nor for participation of personne? not in the immediate vicinity of the site.

An appropriate plan would (1) identify accidents for which protective actions should be taken by people offsite. (2) list the licensee's responsibilities for each type of accident, including notification of local authorities (fire and police generally), and (3) give sample messages for local authorities including protective action recommendations. This approach more closely follows the approach used for research reactors than for power reactors. The low potential offsite doses (acute fatalities and injuries not possible except possibly for $U_{6}$ releases), the small areas where actions would be warranted, the small number of people involved, and the fact that the local police and fire departments would be doing essentially the same things they normally do, are all factors that tend to make a simple plan adequate. 



\section{CONTENTS}

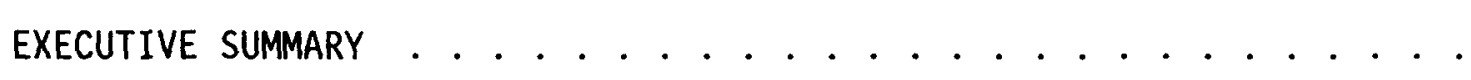

ACKNOWLEDGEMENTS ................................ Xi

1. PROPOSED ACTION . . . . . . . . . . . . . . . . . . . . . . . 1

1.1 Description of the Proposed Action . . . . . . . . . . . . . . . .
1.2 Need for the Proposed Action . . . . . . . . . . . . . . . 4

2. TECHNICAL BASIS FOR THE PROPOSED RULE . . . . . . . . . . . . . . 6

2.1 Methodology ................... 6

2.1.1 The Accident History Approach . . . . . . . . . . . 6

2.1.2 Accident Source Terms . . . . . . . . . . . . . . 8

2.1.3 Calculations of Doses................ 9

2.1.4 Protective Action Guides . . . . . . . . . . . . . . 14

2.1.5 A Discussion of the Conservatism in the
Calculations . . . . . . . . . . . . . . 16

2.2 Fuel Cycle Facilities . . . . . . . . . . . . . . . 19

2.2.1 Uranium Mining . . . . . . . . . . . . . . . . . . 19

2.2.2 Uranium Milling................... . 19

2.2.3 UF $\mathrm{UF}_{6}$ Conversion Plants . . . . . . . . . . . . 27

2.2.4 Enrichment Plants................ 40

2.2.5 Fuel Fabrication - Uranium . . . . . . . . . . . 42

2.2.6 Fuel Fabrication - Plutonium ........... . 53

2.2.7 Spent Fuel Storage . . . . . . . . . . . . . 59

2.2.8 New Fuel Storage ................. 62

2.2.9 Reprocessing of Spent Fuel . . . . . . . . . . . 62

2.2.10 Research with Nuclear Fuels............ . 67

2.3 Byproduct Material Facilities ............. 69

2.3.1 A Generic Overview . . . . . . . . . . . . . 70

2.3.2 Radiopharmaceutical Manufacturing .......... 84

2.3.3 Radiopharmacies and Hospitals . . . . . . . . . . 86

2.3.4 Sealed Source Manufacturing . . . . . . . . . . . . . 88

2.3.5 University Research Laboratories . . . . . . . . . . 90

2.3.6 Waste Warehousing and Burial . . . . . . . . . . . 94

2.3.7 Depleted Uranium Products . . . . . . . . . . . . 96

2.4 Summary of Facilities to be Covered . . . . . . . . . . . 99

2.5 A Protective Action Strategy ............... . 101 
2.5.1 The Initial Response ................ 101

2.5.2 Locating Contamination. . . . . . . . . . . . . . . 105

2.5.3 The Assessment Phase . . . . . . . . . . . . 105

3. VALUE/IMPACT . . . . . . . . . . . . . . . . . . 106

3.1 Alternatives .. . . . . . . . . . . . . . . . 106

3.2 Value of the ProposedAction . . . . . . . . . . . . . . 107

3.3 Cost . . . . . . . . . . . . . . . . . . . . . 109

3.4 Value/Impact of Alternatives............. . 109

4. STATUTORY CONSIDERATIONS . . . . . . . . . . . . . . . . 110

4.1 NRC Regulatory Authority . . . . . . . . . . . . . . 110

4.2 Agreement States...................... . . . . . . 110

4.3 Environmental Impact Appraisal . . . . . . . . . . . . 110

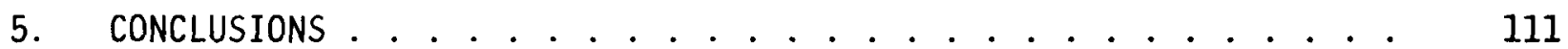

FIGURE

1. Atmospheric dispersion versus distance . . . . . . . . . . . 13

TABLES

1. Fires in Uranium Mills through 1986 . . . . . . . . . . . . . . . 21

2. Uranium Mill Tajlings Releases, 1959-1986 . . . . . . . . . . . . 22

3. Accident Source Terms and Doses From Uranium Mill Accidents . . . 24

4. Accidents Involving $U_{6}$ Releases through 1986 . . . . . . . . . . 29

5. Criticality Accidents In Fuel Cycle Facilities through $1986 . . .43$

6. Fires and Explosions Involving Uranium and Thorium through

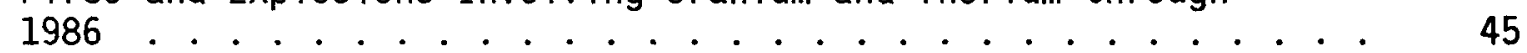

7. Other Accidental Releases from Uranium Fuel Fabrication Plants through 1986 ......................... . . . . . 46

8. Amounts of Radioactive Materials Released to Room Air Due to a Criticality Accident .. . . . . . . . . . . . . . . 48

9. Offsite Doses Calculated for Fuel Fabrication Plants . . . . . . 50

10. Calculated Releases and Doses from Spent Fuel Storage Accidents . 63

11. Fires and Explosions Involving Release of Byproduct Materials through 1986 . . . . . . . . . . . . . . . . . . . . . . . . . 71

12. Accidental Releases of Byproduct Material Except Fires
and Explosions through 1986 . . . . . . . . . . . . . . . . 72

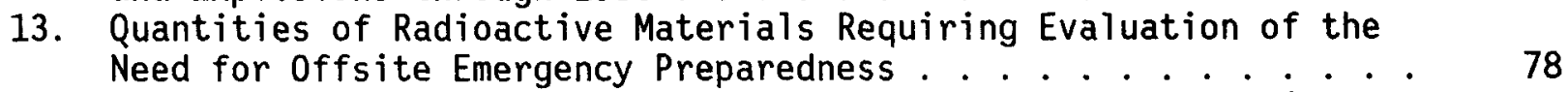

14. Radiopharmaceutical Manufacturing: Maximum Possession Limits,

15. Radiopharmacy: Maximum Possession Limits, Release Fractions,
and Doses Due to a Major Facility Fire . . . . . . . . . . 88 


\section{CONTENTS (Continued)}

Page

TABLES (Continued)

16. Sealed Source Manufacturing: Maximum Possession Limits, Release Fractions, and Doses Due to a Major Facility Fire . . . . 91

17. University Research Laboratories: Maximum Possession Limits Release Fractions, and Doses Due to a Major Fire . . . . . . . . 93

18. Waste Warehousing Airborne Releases and Doses Due to a Major Facility Fire . . . . . . . . . . . . . . . . . . . . . . . . . 95

19. Comparison of Costs and Benefits of Special Emergency Preparedness 



\section{ACKNOWLEDGEMENTS}

We would like to thank the following people for helping us prepare this Regulatory Analysis.

David Bennett, Eugene Runkle, Daniel Alpert, Kenneth Adams, and David Aldrich of Sandia National Laboratory for performing dose calculations and meterological modeling.

Peter Owczarski, Sue Sutter, Jofu Mishima, and Mark Halverson of BattellePacific Northwest Laboratory for performing release fraction experiments, analyzing release fraction experiments, reviewing the literature on release fractions, developing accident scenarios, and analyzing accidents.

Moshe Simon-Tov and Reid Williams of Martin-Marietta Energy Systems, Oak Ridge, for performing analyses of $U_{6}$ releases. Robert Just for discussions on the health effects of $\mathrm{UF}_{6}$.

Bruce Hicks of the National Oceanic and Atmospheric Administration for reviewing calculations of uranium haxafluoride releases.

Andreas Jensen of the John Hopkins University Applied Physics Laboratory for descriptions of the U.S. Department of Transportation accident modeling methods.

Joseph Logsdon of the U.S. Environmental Protection Agency for discussions on the use of the EPA's protective action guides.

Paul Morrow of the University of Rochester and McDonald Ed Wrenn of the University of Utah for discussion on the chemical toxicity of uranium.

Duane Hall of $3 \mathrm{M}$ for hosting a tour of the $3 \mathrm{M}$ sealed source manufacturing plant in New Brighton, Minn, and for discussion on the release fractions of polonium-210.

Edward Janzow of Monsanto Research Corporation for hosting a tour of the Monsanto Dayton, Ohio, sealed source manufacturing plant and for information on the particle size of americium oxide powder.

Melita Rodeck of the Federal Emergency Management Agency for helpful comments.

Al Arcuni and Sandy Mullen of International Energy Associates Limited for helpful comments. 
On the NRC's Office of Nuclear Material Safety and Safeguards staff: Fritz Storz, Lee Rouse, and John Roberts for assistance in preparing the section on spent fuel storage; Dennis Sollenberger and George Gnugnoli for assistance in preparing the section on uranium milling; Fred Fisher, Ed Shum, and R. Gerry Page for suggestions throughout the analysis; Joseph Wang for assistance in preparing sections in byproduct material licensees; Ron Cardarelli for help in collecting information in emergency plans submitted to NRC.

On the NRC's Office of Nuclear Regulatory Research staff: Steven Bernstein and Don Solberg for assistance on accident scenarios and release fractions, as well as contract assistance; Robert Kornasiewicz and Leta Brown for comments and assistance on meterological modeling; James Martin and Leonard Soffer for comments and assistance with regard to existing NRC policy on emergency preparedness, especially as it relates to nuclear power plants; Michael Jamgochian, James Norberg, Philip Ting, Robert Bernero, Frank Gillespie, James Malaro, and Karl Goller for many helpful comments and valuable support.

On the NRC's Office of Nuclear Reactor Regulation staff: Irwin Spickler for many valuable comments and discussions on meterological modeling.

On the NRC's Office of Analysis and Evaluation of Operational Data staff: Kathleen Black and Eugene Trager for help in collecting information on accident histories. 


\title{
A REGULATORY ANALYSIS
}

\author{
ON \\ EMERGENCY PREPAREDNESS FOR FUEL CYCLE \\ AND OTHER RADIOACTIVE MATERIAL LICENSEES
}

1. PROPOSED ACTION

\subsection{Description of the Proposed Action}

This regulatory analysis evaluates the need for a proposed rule to require additional emergency preparedness for certain fuel cycle and other radioactive material licensees. The purpose of the rule would be to require, for certain licensees who are authorized to possess radioactive materials in large quantity, emergency plans for responding to releases of radioactive materials. These plans would include:

(1) Facility description: A brief description of the licensee's facility and area near the site.

(2) Types of accidents: An identification of each type of accident for which protective actions may be needed.

(3) Classification of accidents: A classification system for classifying accidents as alerts or site area emergencies.

(4) Detection of accidents: Identification of the means of detecting each type of accident in a timely manner. 
(5) Mitigation of consequences: A brief description of the means and equipment for mitigating the consequences of each type of accident, including those provided to protect workers onsite, and a description of the program for maintaining the equipment.

(6) Assessment of release: A brief description of the methods and equipment to assess releases of radioactive materials.

(7) Responsibilities: A brief description of the responsibilities of licensee personnel should an accident occur, including identification of personne 1 responsible for promptly notifying offsite response organizations and the NRC; also responsibilities for developing, maintaining, and updating the plan.

(8) Notification and coordination: A commitment to and a brief description of the means to promptly notify offsite response organizations and request offsite assistance, including medical assistance for the treatment of contaminated injured onsite workers when appropriate. A control point must be established. The notification and coordination must be planned so that unavailability of some personnel, part of the facility, and some equipment will not prevent the notification and coordination. The licensee shall also commit to notify the NRC immediately after notification of the appropriate offsite response organizations and not later than one hour after the licensee declares an emergency.

In addition, the licensee shall notify the U.S. Coast Guard National Response Center immediately after the size of the release has been assessed if the estimated quantity of material released exceeds the reportable quantities established by the U.S. Environmental Protection Agency.

(9) Information to be communicated: A brief description of the types of information on facility status, radioactive releases, and recommended actions, if necessary, to be given to offsite response organizations and to the NRC. 
(10) Training: A brief description of the training the licensee will provide workers on how to respond to an emergency and any special instructions and orientation tours the licensee would offer to fire, police, medical, and other emergency personnel.

(11) Safe shutdown: A brief description of the means of restoring the facility to a safe condition after an accident.

(12) Exercises: Provisions for conducting quarterly communications checks with offsite response organizations and annual onsite exercises to test response to simulated emergencies. Quarterly communications checks with offsite response organizations shall include the check and update of all necessary telephone numbers. The licensee shall invite offsite response organizations to participate in the annual exercises. Participation of offsite response organizations in annual exercises although recommended is not required. Exercises must use scenarios not known to exercise participants. The licensee shall critique each exercise using individuals not having direct implementation responsibility for the plan. Critiques must evaluate the appropriateness of the plan, emergency procedures, facilities, equipment, training of personnel, and overall effectiveness of the response. Deficiencies found by the critiques must be corrected.

(13) Hazardous chemicals: A verification of the applicant's compliance with the Emergency Planning and Community Right-to-Know Act of 1986, Title III, Pub. L.99-499, if applicable to the applicant's activities at the proposed place of use of the special nuclear material.

The question is not whether licensees should have any emergency preparednes:. That question was addressed long ago. The NRC has long required licensees to be prepared to cope with emergencies. The question is whether there should be additional requirements. For example, should NRC require formal written state and local government plans for coping offsite with serious radiation accidents? Such plans might include provisions for early evacuation by the public or notifying them to take shelter indoors.

The question is also not whether State and local governments should have emergency preparedness capabilities for dealing with radiation accidents. 
Police departments, fire departments, state radiological health departments, and other agencies that are routinely prepared to cope with emergencies al ready exist. This rulemaking is intended to assure that, where needed, there exist emergency procedures for mitigating and coping with offsite releases.

We must also distinguish between emergency response and formal emergency plans. If an accident happens, the licensee and State and local governments can be expected to respond to the best of their abilities whether or not there are any formal written emergency plans for offsite releases.

\subsection{Need for the Proposed Action}

The NRC has always required that its licensees take steps to reduce the likelihood of serious accidents to a minimal level, but yet be prepared to cope with accidents should they occur. However, during the Commission's deliberations on rulemaking concerning nuclear power plant emergency preparedness following the accident at Three Mile Island, the Commission directed the staff to evaluate the need to strengthen the emergency preparedness requirements for fuel cycle and other radioactive material 1 icensees.

In late 1980, the staff reevaluated previously submitted emergency plans for fuel fabrication plants and found some weaknesses in the plans as written. For example, some plans did not describe (1) timely alerting of potentially affected public to a hazard, (2) recommendations for specific actions the public should take to protect itself, such as sheltering or evacuation, and (3) arrangements for prompt notification of NRC and state and local government agencies.

In February, 1981, the NRC issued orders to 62 licensees to either submit comprehensive radiological emergency plans or lower their possession limits for radioactive material. About half of the licensees submitted plans, and half lowered their possession limits or surrendered their license. Then, an Advance Notice of Proposed Rulemaking on the subject of offsite emergency preparedness was published in the Federal Register on June 3, 1981 (46 FR 29712).

In the Advance Notice the Commission proposed to codify, with some modifications, the radiological emergency requirements set forth in the orders. $A$ public comment was that there is no need for emergency plans for those facilities because the offsite consequences of a credible accident would be so small. 
On April 20, 1987, the NRC published a Notice of Proposed Rulemaking to establish in its regulations a formal basis for the plans required by order. Seventeen public comments were received. Nine were from licensees who would be affected by the regulation, and three were from States who would have a role in responding to an accident.

The comments raised two types of significant policy questions. The first type said that the rule should not be adopted because it was not needed or not useful. These comments generally stated that the analyses and accident scenarios were too conservative, that actual doses would be far lower than those calculated, that credit should be given for engineered safeguards, that plans should only be required if doses could exceed 5 rems instead of 1 rem, that the costs far outweight the benefits, or that accident would happen so quickly that no offsite response could be effective at reducing offsite exposures, regardless of cost.

In the end, the staff rejected these arguments. The staff agreed that the calculations are conservative, that doses in an actual accident would probably be lower than calculated, that the probability of a large release is very small, and that some accidents could happen so quickly that the response would not be effective at lowering doses. Nevertheless, the Commissioners considered that an emergency plan to be an integral part in protecting public health and safety. There is no assurance that emergency response would always be effective at reducing exposures offsite or that specified dose levels must not be exceeded. The requirement should be that the licensee must be prepared to take practical steps that could, in favorable circumstances, reduce radiation exposures of the public.

The other type of comment said that the rule should require the licensee to have a system to promptly warn the public offsite of an accident and be required to give information brochures annually to people near the facility.

These arguments were also rejected. The licensee has the responsibility to prevent serious accidents. Should that fail, the responsibility for protecting the public near the facility is considered to belong to offsite public safety authorities. The rule would require the licensee to immediately notify those authorities of serious accidents. It is expected that, in general, the authorities would then notify the public in a manner similar to what is done for truck and rail accidents involving hazardous chemicals. Similarly, the rule would leave the decision on public information brochures to local authorities. 


\section{TECHNICAL BASIS FOR THE PROPOSED RULE}

\subsection{Methodology}

This regulatory analysis identifies the classes of fuel cycle and other radioactive material licensees that could have accidents that might result in radiation doses to the public exceeding protective action guides established by the EPA. (Chemical toxicity is also considered for the special case of uranium hexafluoride and soluble uranium releases.) The plausibility of exceeding the EPA's protective action guides was considered from two points of view: (1) the accident history of fuel cycle and byproduct material licensees, and (2) theoretical calculations of the releases and offsite doses of accidents considered to be possible.

\subsubsection{The Accident History Approach}

The history of accidents involving radioactive byproduct material (Part 30 licensees), source material (Part 40 licensees), special nuclear material (Part 70 1icensees), and spent fuel storage (Part 721 icensees) was surveyed. In summary, we found no evidence that any accidental release of radioactive material from facilities of these types has ever caused an effective dose equivalent to any individual offsite exceeding even $1 \%$ of the EPA's 1 -rem protective action guide.

The value of the historical review is that it identifies types of accidents that have occurred and draws our attention toward accidents similar to those that have occurred. In addition, accidents that have happened cannot have violated the physical laws of nature. This statement cannot be made about theoretical calculations. Theoretical calculations can use simplifying assumptions that are internally inconsistent or inconsistent with the laws of nature.

More information on the nature, causes, and frequency of accidents is available for fuel cycle and other radioactive material licensees than is available for nuclear power plants because there are so many more fuel cycle and other radioactive material licensees than nuclear power plants. Currently the NRC regulates about 9,000 non-reactor licensees. In addition, Agreement States regulate roughly another 12,000 non-reactor licensees. A large number of these licensees have operated for many years, and the combined experience 
of these licensees approaches half a million licensee-years. By contrast, there are only about 110 U.S. nuclear power plants operating with about 1,000 plantyears of combined operating experience. Thus more experience exists for fuel cycle and other radioactive material licensees than exists for nuclear power plants.

Operating experience may be more relevant for these licensees than for nuclear power plants because of the nature of the accident driving force. In nuclear power plants the driving force is the enormous amount of heat in the reactor. The available energy is so large that some unique occurrences are conceivable, such as molten cores, large-scale metal-water reactions, and rupturing the containment by overpressurization. Because these events have never happened they can only be studied theoretically. The dominant driving forces for accidents at non-reactor licensees are common industrial accidents-fires, chemical explosions, leaks, and the like. A great deal of industrial accident experience can be drawn upon in analyzing these potential accidents.

Much information on the accident history of fuel cycle and other radioactive material licensees is available. NRC regulations require the reporting of all significant events. All licensees must notify NRC of (1) the overexposure of any individual to radiation [10 CFR $\$ 20.403$ and $\$ 20.405]$, (2) the airborne release of large quantities of radioactive material [10 CFR \$20.403 and $\$ 20.405]$, (3) the loss of one day or more of the operation of any facility [10 CFR \$20.403], (4) damage to property in excess of $\$ 2000$ [10 CFR \$20.403], (5) the loss or theft of licensed material [10 CFR \$20.402], (6) excessive radiation levels or contamination on packages received [10 CFR \$20.205], and (7) major defects in equipment or noncompliance with regulations that have major safety significance [10 CFR \$21.21]. In addition, there are other reporting requirements in NRC regulations that apply to specific classes of licensees. The reports that licensees have filed provide extensive information for evaluating the history of accidents in this part of the nuclear industry. Since January 1975, the NRC has carefully and systematically published reports describing accidents of significance, "Report to Congress on Abnormal 0ccurrences," NUREG-0090. Accidents in the fuel cycle and at byproduct material facilities are included for NRC 1 icensees and Agreement State licensees. A11 these reports for the period from January, 1975, to December, 1986, were reviewed for this Regulatory Analysis. 
Also, a comprehensive file of over 5,000 events from the period of 1950 through 1978 was compiled at Argonne National Laboratory. The file includes primarily events from NRC licensees (formerly AEC licensees) and governmentowned laboratories run by DOE (formerly ERDA and AEC), and some reports on accidents from Agreement State licensees and facilities in foreign countries. The file includes events from nuclear power plants, the nuclear fuel cycle, and other radioactive material usage. A brief summary of 1634 events in the commercial nuclear fuel cycle was published in 1981.* The Argonne file also includes some events from 1979, but is not complete for that year.

In addition, other sources were searched for this analysis, such as NRC's annual reports on radiation exposures, NRC's preliminary notification of unusual event reports, the memory of NRC staff members, and accounts published in the open literature.

Using all these sources of information this analysis should include most significant accidents for the years from 1950 through 1986. Although some events may have been omitted, it is believed that all relevant events in the United States that caused a significant release of radioactive material outside a restricted area have been included.

\subsubsection{Accident Source Terms}

Many plausible accident scenarios were considered for various types of facilities. The NRC considers in Safety Evaluation Reports a number of possible accidents and their effects on public health and safety before issuing licenses for fuel cycle facilities. The NRC requires applicants to evaluate possible accidents. Additionally, the NRC performs its own analyses of several severe accidents to determine whether there is adequate protection of public health and safety. The NRC's analyses are then issued when the license is issued. This regulatory analysis makes use of those NRC staff analyses in developing accident source terms.

*Deborah J. Bodeau et al., Data Base for Radiation Events in the Commercial Nuclear Fuel Cycle, 1950-1978, Argonne National Laboratory, NUREG/CR-2429, ANL/ES-123, March 1982. 
The significant accidents were determined to be $\mathrm{UF}_{6}$ releases, fires, and criticality accidents. Aside from the special cases of $U_{6} F_{6}$ releases and criticalities, the release fractions for fires were considered to be larger than the release fractions for other types of accidents. Thus, release fractions for fires, as described in Section 2.3.1.2, are used to determine the need for emergency preparedness.

\subsubsection{Calculations of Doses}

Doses from airborne releases were calculated by assuming release fractions for radioactive materials, assuming a atmospheric dispersion model, and calculating doses from three pathways-inhalation, cloud-shine, and ground-shine from particulates deposited on the ground. In general, the highest doses come from inhalation.

Two kinds of doses were calculated: effective dose equivalent and child's thyroid dose.* The effective dose equivalent is the sum of the 50-year dose equivalent commitment to each body organ multiplied by a weighting factor for each organ as given in ICRP Publication 26 and, for the skin, ICRP Publication 28.** For the inhalation pathway, dose conversion factors from ICRP Publication $30^{\star * *}$ were used. Thyroid dose is the dose equivalent delivered to the thyroid by inhaled radioiodines. The child's thyroid dose is calculated by multiplying the value calculated for an adult by two.

For the two external dose pathways dose conversion factors from Kocher**** were used. An 8-hour ground exposure time and a 0.7 shielding factor ${ }^{\dagger}$ (30\%

*David E. Bennett et al., Preliminary Screening c Fuel Cycle and Byproduct Material Licenses for Emergency Planning," Sancid National Laboratories, NUREG/CR-3657, SAND84-0186, Apri1 1985 .

$* *$ Statement from the 1978 Stockholm Meeting of the ICRP, Publication 28, International Commission on Radiological Protection, Pergamon Press, Oxford, 1978.

*** Limits for Intakes of Radionuclides by Workers, Publication 30 , International Commission on Radiological Protection, Pergamon Press, Oxford, 1979 and 1980.

****D. C. Kocher, "Dose-Rate Conversion Factors for External Exposure to Photon and Electron Radiation from Radionuclides Occurring in Routine Releases from Nuclear Fuel Cycle Facilities," ORNL, NUREG/CR-1918, 1981. Also D. C. Kocher, "Dose-Rate Conversion Factors for External Exposure to Photons and Electrons, "Health Physics, 45, 665, 1983.

†"Reactor Safety Study," NRC Report WASH-1400, Appendix VI, page 11-23, 1975. 
reduction) for a not perfectly flat surface were used to calculate the external exposure from radionuclides deposited on the ground. The basis for the 8-hour exposure to ground shine is that even if there is no pre-existing offsite emergency preparedness it should be possible to locate areas with high dose rates due to ground shine (greater than $100 \mathrm{mR} / \mathrm{hr}$ ) and move people out within 8 hours. The contaminated areas from which people would need to relocate would be small and generally near the site.

The atmospheric dispersion model is a standard Gaussian plume model. Doses were calculated for two sets of meteorological conditions: stability class $F$ with $1 \mathrm{~m} / \mathrm{s}$ wind speed and stability class $D$ with $4.5 \mathrm{~m} / \mathrm{s}$ wind speed. The $F$, $1 \mathrm{~m} / \mathrm{s}$ assumptions are those traditionally used by NRC in hazard evaluations and represent very adverse weather conditions. The $D, 4.5 \mathrm{~m} / \mathrm{s}$ assumptions are those traditionally used by DOT in calculating evacuation distances for accidents involving toxic chemicals $f$ and represent more typical weather. DOT considers evacuation distances based on $D, 4.5 \mathrm{~m} / \mathrm{s}$ adequate to protect public health and safety as demonstrated by experience with toxic chemical releases. The NRC's proposed rule associated with this analysis bases the need for emergency preparedness on the traditional NRC assumptions if $F, 1 \mathrm{~m} / \mathrm{s}$. The doses calculated using the DOT assumptions of $D, 4.5 \mathrm{~m} / \mathrm{s}$ are included for perspective to show doses that would be expected under more typical or realistic conditions.

The intercept fraction for inhalation of $10^{-6}$ is considered to be about the maximum value likely to be inhaled in an accident. * Using $F, 1 \mathrm{~m} / \mathrm{s}$ meteorology and the assumptions described below, 10-6 corresponds to a distance of 100 meters for the entire duration of the accident. Limiting the intake to 10-6 in effect means that a person on the plume centerline in dense smoke closer than 100 meters from the release point will move out of the smoke before the release ends. Thus, the distance at which doses were calculated was taken to be $100 \mathrm{~m}$ from the release point in our mathematical model. This distance results in an intercept fraction of $0.89 \times 10^{-6}$ for radioactive materials that deposit on the

†"Hazardous Materials-Emergency Response Guidebooks, "Materials Transportation Bureau, U.S. Department of Transportation, DOT Publication DOT-P5800.2, 1980.

*"Upgraded Emergency Preparedness for Certain Fuel Cycle and Material Licensees," 46 Federal Register 29712, 1981; "Criteria for Selection of Fuel Cycle and Major Materials Licensees Needing Radiological Contingency Plans," NUREG-0767, 1981; and Allen Brodsky, "Resuspension Factors and Probabilities of Intake of Material in Process (or Is 10-6 a Magic Number in Health Physics?)" Health Physics, 39, 992, 1980. 
ground. In other words a person on the plume centerline is assumed to inhale at most about one one-millionth of the material released.

Doses were calculated for a person standing in an open field in the downwind direction on the plume centerline breathing at a rate of $2.66 \times 10^{-4} \mathrm{~m}^{3} / \mathrm{s}$. Atmospheric stability class $F$ and wind speed of $1 \mathrm{~m} / \mathrm{s}$ were assumed. Doses to people in buildings would be smaller than the doses given in this analysis because buildings provide shielding and some respiratory protection. Doses to people standing outside in urban and suburban areas or wooded areas would be less than those given here because obstacles to wind flow would cause the plume to broaden.

Doses were calculated using a slightly modified version of the CRAC2 computer code.* The CRAC2 code has been used extensively by the NRC for calculations of doses that could result from nuclear power plant accidents.

The key input parameters for the CRAC2 calculations are building size, release duration, release height, dose conversion factors for each radionuclide, radioactive halflife of each radionuclide, and deposition velocity for particulates.

Building size determines the building wake factor or the initial plume dimension. In most cases the building size was assumed to be $25 \mathrm{~m}$ wide by $10 \mathrm{~m}$ high. For buoyant releases no building wake factor was used. At close in distances the building wake effect from a $250 \mathrm{~m}^{2}$ building significantly reduces the concentrations of airborne materials from a release. At distances of $1000 \mathrm{~m}$, the building wake factor is relatively unimportant.

The release duration determines the amount of plume meander. Plume meander was not included at $100 \mathrm{~m}$ because the plume is considered to be still in the building wake.

Release height determines plume height and thus affects ground level concentrations. Greater release heights cause lower ground level air concentrations. In this regulatory analysis, the release height was assumed to be ground level except that buyancy was considered for $U_{6}$ release.

\footnotetext{
*L.T. Ritchie et al., "CRAC2 Model Description," Sandia National Laboratories, NUREG/CR-2552, SAND82-0342, Apri1 1984.
} 
The CRAC2 code accounts for the radioactive decay of materials in transit. In most cases this correction is negligible. However, $\mathrm{Kr}-89$ with a 3-minute half-life dominates the external dose from a criticality accident, so that in this case the decay correction is significant.

The CRAC2 code does not calculate radioactive decay while a material is held up in a building before release. A separate correction factor was developed to account for radioactive decay before release to the atmosphere. This factor was used to reduce the quantities of short-lived radionuclides for criticality accidents.

In calculating external dose due to clouds, the CRAC2 code performs the calculation for a finite-size cloud rather than an infinite-size cloud. The difference between the two can be substantial at distances as close as $100 \mathrm{~m}$ for stable atmospheric conditions. For example, failure to correct for this factor at $100 \mathrm{~m}$ from a point release (i.e., no building wake) during class $\mathrm{F}$ stability would cause external doses to be overestimated by a factor of almost 40 . However, the finite cloud correction factor is much smaller when building wake factors are used.

The results of the atmospheric dispersion calculations for inhalation are shown in Figure 1 for both $F, 1 \mathrm{~m} / \mathrm{s}$ and $D, 4.5 \mathrm{~m} / \mathrm{s}$ assumptions. Figure 1 , giving $X / Q$ in $s / \mathrm{m}^{3}$, can be used to calculate inhalation dose $D$ in rems due to a released quantity $Q$ in $u C i$ by using the equation:

$$
D=D C F \times B \times \times / Q \times Q
$$

where: $\begin{aligned} D C F= & \text { dose conversion factor, rems/uCi inhaled, as given in } \\ & \text { Table } 13 \text { and }\end{aligned}$

$$
B=\text { breathing rate, which is } 2.66 \times 10^{-4} \mathrm{~m}^{3} / \mathrm{s} \text {. }
$$

The doses due to ground-shine and cloud-shine should be added to the inhalation dose to obtain a person's total dose. As a practical matter, however ground-shine and cloud-shine doses will be considerably smaller than the inhalation dose except for a few radionuclides (xenon, krypton, Na-24, Mn-56, Tc-99m, and $\mathrm{Ru}-105)$. 


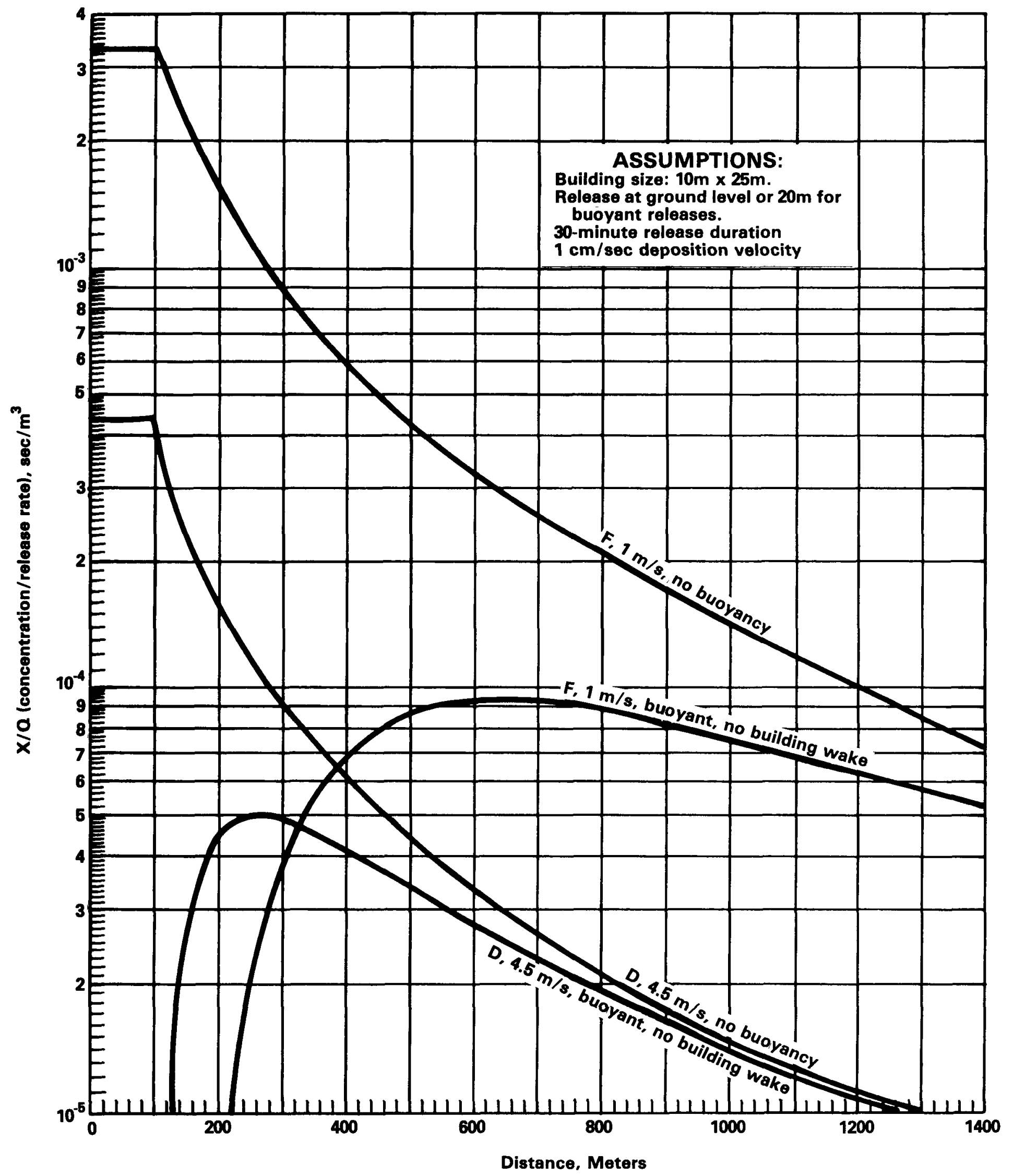

Figure 1. Atmospheric dispersion versus distance. 


\subsubsection{Protective Action Guides}

Protective action guides are expressed in terms of projected doses to individuals in the population which warrant taking protective action. The EPA has published draft guides for taking protective action in order to avoid exposure to radiation as the result of an accident at a nuclear power plant.* The EPA recommends that protective actions should be considered by responsible officials if projected whole body doses are in the range of 1 to 5 rems. The lower dose of 1 rem is a level which "should be used if there are no major local constraints in providing protection at that level, especially to sensitive populations" (children and pregnant women). The EPA believes that "in no case should the higher value ( 5 rems) be exceeded in determining the need for protective action." Put another way, protective actions may be considered optional at 1 rem, to be taken if readily feasible, but are highly recommended at 5 rems if at all feasible. Note that the 1-rem and 5-rem doses are projected doses that might occur after the protective action decision. Doses received prior to the decisionmaking and during the protective action implementation time are not considered in the decisionmaking. Only dose savings as a result of taking a protective action are to be used in determining whether such protective action is warranted.

For radioactive materials that deliver dose to the body nonuniformly after they are inhaled, the resulting effective dose equivalent is compared to the EPA's protective action guides. The effective dose equivalent, as defined in the previous section, is the sum of the external gamma dose equivalent, the dose equivalent delivered to each body organ multiplied by a weighting factor for the organ from ICRP Publication 26, and the external beta dose equivalent delivered to the skin multiplied by the weighting factor from ICRP Publication 28. The factors used to convert intake of radionuclides to an effective dose equivalent are taken from ICRP Publication 30.

The Commission's policy on the use of the EPA's protective action guides to establish planning zones for nuclear power plants is stated in NUREG-0654. **

\footnotetext{
*EPA-520/1-75-001, "Manual of Protective Action Guides and Protective Actions for Nuclear Incidents," Draft Revision of June, 1980.

**NUREG-0654/FEMA-REP-1, Revision 1, "Criteria for Preparation and Evaluation of Radiological Emergency Response Plans and Preparedness in Support of Nuclear Power Plants," joint NRC/FEMA Report, 1980, page 12.
} 
"The size (about 10 miles radius) of the plume exposure emergency planning zone was based primarily on the following considerations:

a. projected doses from the traditional design basis accidents would not exceed protective action guide levels outside the zone;

b. projected doses from most core melt sequences would not exceed protective action guide levels outside the zone;

c. for the worst core melt sequences, immediate life threatening doses would generally not occur outside the zone;

d. detailed planning within 10 miles would provide a substantial base for expansion of response efforts in the event that this proved necessary."

For nuclear power plants the traditional design basis accident assumes the containment does not fail. In other words, one major barrier to a radioactive release remains. Failure of all engineered safeguards is evaluated with respect to life threatening doses rather than protective action guides in the 1 to 5 rem range. In addition, emergency preparedness does not guarantee there will be no loss of life for the worst case imaginable.

A later report elaborates on the Commission policy. NUREG-0771* states:

"For the small releases, the lower ranges of the protective action guides (PAG) would be used as the appropriate measure to base planning. For somewhat larger releases, the criteria shift to the upper ranges of the PAG and levels of exposures which would still be less than medically detectable. For intermediate level releases early injuries would be used as the measure to base the EPZ distance judgment on. Finally, for the most severe accidents, early fatalities become the immediate concern and therefore the measure to base the criteria upon..."

\footnotetext{
*NUREG-0771, "Regulatory Impact of Nuclear Reactor Accident Source Term Assumptions," for comment, June, 1981, page 35.
} 
For application to fuel cycle and byproduct material licensees, the lower end of the range ( 1 rem) of the EPA's protective action guides is used in conjunction with calculations of releases and offsite radiation doses due to severe accidents, such as a major facility fire, to establish the need for a plan. Thus the lower range of the protective action guides is used to determine the need for offsite emergency preparedness.

The actual assumptions that were used for each facility type are discussed in separate sections in the remainder of this report. The reasons for selecting the assumptions are also discussed.

\subsubsection{A Discussion of the Conservatism in the Calculations}

The Commission's policy is that, "Emergency planning should be based on realistic assumptions regarding severe accidents."*

The doses calculated in this Regulatory Analysis have been conservatively calculated. Doses to people near a plant experiencing a severe accident are likely to be far below the doses in this analysis, probably by an order of magnitude or more, except in very unusual circumstances. The accident history of such facilities in the U.S. is that there is no known case of a member of the public receiving even as much as $1 \%$ of the doses calculated in this analysis as the result of an accidental airborne release from any nonreactor facility. ** A number of factors which cause this analysis to be conservative are discussed below.

*"U.S. Nuclear Regulatory Commission Policy and Planning Guidance - 1985," U.S. Nuclear Regulatory Commission, NUREG-0885, Issue 4, 1985, page 6.

**For a 1962 release of high-enriched $U_{6}$ from the NFS plant, Erwin, Tennessee, a plume centerline dose equal to $4 \%$ of the 1 -rem effective dose equivalent guide was calculated using conservative assumptions (no deposition, open field diffusion parameters, no wind direction shift, etc.) However, the report stated, "No specific information regarding the presence of individuals during the releases was available." Because no one is known to have stood on or near the plume centerline, we can say there are no known exposures exceeding $1 \%$ of 1 -rem. The dose calculations are contained in an unpublished report, "Dose Assessment of Airborne Releases from NFS-Erwin Fuel Facility 1972-1981," U.S. Nuclear Regulatory Commission, Region II, Atlanta, Georgia, May, 1983. 


\subsubsection{Conservative Factors}

1. Entire possession limit assumed to be involved. In calculating the quantities of radioactive material for which an emergency plan would be needed, this analysis generally assumed that the licensee's entire or nearly entire possession limit would be involved. In actuality, most licensees at any particular time possess much less material than they are legally authorized to possess. In many cases the possessed material will be located at different locations and will not all be subject to release during a particular accident. For example, the National Institutes of Health is authorized to use and store licensed material in more than 1,000 different laboratories.

2. Worst-case release fractions. The release fractions due to fires (the accidents with highest potential release) were determined from experiments designed to maximize releases. In such experiments a finely powdered material is typically placed on top of a large amount of combustible material. Having the entire licensed inventory unenclosed on top of a large quantity of combustible material would be most unusual. Radioactive materials are usually within shielded "pigs" and kept in metal safes or well shielded hot cells or glove boxes. Amounts of combustible materials present are generally kept low.

3. No credit for engineered safeguards or response efforts. No credit is generally given for design or operating features that could reduce releases. No credit is given for sprinkler systems designed to stop fires. Generally, no credit is given for filter systems during a fire. No credit is given for fire fighting efforts to stop the fire before it reaches radioactive materials. Little or no credit is given for holding up the release of the material by means of deposition or plateout. For $U_{6}$ releases outdoors, no credit is given for knocking the uranium out of the air using fire hoses.

4. The exposed individual makes no response. In the case of fires and $U_{6}$ releases, the dose is calculated for a person who stands directly on the plume centerline for 30 minutes. Such a person would be standing in dense smoke or irritating acid fumes. Realistically, people can be expected to move from such positions to avoid smoke inhalation. People close in would only have to move about 20 meters to get completely out of the plume.

5. No plume-rise for smoke. Even where the assumed accident is a large fire no credit is given for plume rise due to buoyancy in calculating the quantities of radioactive material for which an emergency plan would be needed. The smoke is assumed to be released at and remain at ground level. 
6. Conservative dosimetry. The material is assumed to have the solubility which would result in the highest dose per curie inhaled. Particulates are generally assumed to have a size of 1 micron making them highly respirable and transportable.

7. Adverse meteorology. Quantities of radioactive material for which an emergency plan would be needed were calculated for atmospheric stability class $F$ with a $1 \mathrm{~m} / \mathrm{s}$ windspeed. These conditions result in minimal dilution and high plume centerline doses, but also very narrow plumes. It is probable that the actual weather would cause lower doses. For example, doses during a moderately sunny day with average winds would be a factor of 50 times smaller than the doses calculated for the analysis.

8. Open-field site assumed. A rural open-field site is assumed. Greater atmospheric dispersion and thus lower doses would occur at an urban or suburban site. Buildings, trees, or other obstacles in the plume path would broaden the plume. Heat sources would increase the plume height.

9. No wind shifts. Doses are calculated only on the plume centerline. It is assumed that no wind direction shifts occur during the accident. In addition, correction factors for plume meander are conservative; the factors were selected to envelope the experimental data. Normally greater plume meander would be expected.

10. 8-hour criticality. The source term assumes a pulsating criticality with a total of 48 bursts occurring over 8 hours (see Section 2.2.5.2). This is a highly conservative source term.

11. There may be no one standing on the plume centerline. The doses are calculated for single point, and they fall off rapidly as one moves away from the point. Even with no protective actions, the highest dose anyone would receive is likely to be well below the assumed dose.

\subsubsection{Nonconservative Factors}

On the other hand there are certain assumptions in the dose calculations that may be nonconservative in certain instances. These factors are discussed below:

1. Adult doses. Doses are calculated for adults rather than children (except for radioiodine doses which are calculated for children). This is because dose conversion factors for children using modern dosimeter models are generally not available. For some inhaled radionuclides a child standing in 
the plume may perhaps receive a dose 2 or 3 times higher than an adult standing at the same location.

2. Breathing rates. The breathing rate used in the dose calculations $\left(2.66 \times 10^{-4} \mathrm{~m}^{3} / \mathrm{s}\right)$ represents an average breathing rate. Breathing rates for above average activity would be higher.

3. Site-specific factors not considered. The table of quantities of material for which emergency planning should be considered was based on assumptions (for example building wake) that would usually be conservative, but may not be conservative for all instances. For example, the building wake factor for a particular building could be less than assumed although it would generally be larger. This should be a minor factor. Any increases in dose due to such factors would not be significant in size by comparison with the sizes of the conservatisms discussed above.

\subsection{Fuel Cycle Facilities}

\subsubsection{Uranium Mining}

Uranium mining is not considered in this report because the NRC has no regulatory jurisdiction over uranium mining. Uranium mining is regulated instead by the Mine Safety and Health Administration, the Environmental Protection Agency, and the individual states.

\subsubsection{Uranium Milling}

Uranium mills extract uranium from ore that typically averages about 1 part per 1000 uranium. The mills produce concentrated uranium compounds, which are shipped out in 55 gallon drums, and waste "tailings," which contain radium-226 and thorium-230 not removed from the ore by the mill processes. In late 1984 there were about 10 full-scale uranium mills operating in the U.S. In addition, there are smaller facilities that perform some of the processes found in milling. Roughly half the mills are licensed by the NRC. The others are licensed by Agreement States.

In addition, this section considers "in-situ" solution uranium mining, in which a solution that has leached uranium from the ground is pumped up and uranium extracted from the solution. 


\subsubsection{Accident History}

Uranium mills have experienced major fires and accidental releases from tailings ponds due to dam failures or tailings line breaks.

Uranium mills have a potential for large fires because large quantities of kerosene are used as a solvent to extract uranium in one mill process. The kerosene contains dissolved uranium and is contained in large open tanks. Two large fires in solvent extraction circuits have occurred. Table 1 lists fires known to have occurred. It is notable that the fires that have occurred have caused little release of radioactive material even though two of the fires were very intense.

Aside from fires, the other notable type of accident at uranium mills has been tailings pond releases. There have been at least 16 instances where uranium mill tailings solids and liquids were released from tailings impoundments. Table 2 describes these releases. In no instances were there radiation dose rates that would cause doses to the public in the range of the EPA's protective action guides. In no case was drinking water contaminated above NRC limits (Appendix B of 10 CFR Part 20).

\subsubsection{Accident Source Terms}

Potential releases of radioactive materials and potential doses that could result from accidents at uranium mills are shown in Table 3 . The largest potential releases were determined to occur as a result of: (1) fires, (2) undetected failures of air cleaning systems, (3) tailing pond releases, and (4) tornadoes. Some reported calculations of the quantities released and projected offsite doses are shown in Table 3.

These calculations show that the largest offsite radiation doses would be due to a fire in the solvent extraction circuit or an undetected failure of the air cleaning system servicing the yellowcake drying area. However, the undetected failure of the air cleaning system servicing the yellowcake drying area does not provide a basis for actions to protect the public. As long as the failure remains undetected no emergency plan can be activated and no protective actions can be taken. As soon as the failure is detected, the release can be stopped by turning off the ventilation blowers. Airborne concentrations 
Table 1. Fires in Uranium Mills through 1986.

\begin{tabular}{|c|c|c|c|}
\hline Date & Mill & $\begin{array}{c}\text { Fire } \\
\text { Description }\end{array}$ & Offsite release \\
\hline $3-19-59$ & $\begin{array}{l}\text { Vanadium Corp., } \\
\text { of America, } \\
\text { Durango, CO }\end{array}$ & $\begin{array}{l}\text { Fire in yellowcake } \\
\text { dryer }\end{array}$ & None detected \\
\hline $6-25-65$ & $\begin{array}{l}\text { American Metal, } \\
\text { Grand Junction, } \\
\text { CO }\end{array}$ & $\begin{array}{l}\text { Fire in ore } \\
\text { dryer for } 3-5 \mathrm{~min} \text {. } \\
\$ 2600 \text { damage }\end{array}$ & None detected \\
\hline $2-68$ & $\begin{array}{l}\text { Western Nuclear, } \\
\text { Jeffery City, WY }\end{array}$ & $\begin{array}{l}\text { Workers started a } \\
\text { fire to thaw a frozen } \\
\text { ore dryer. Fire } \\
\text { ignited propane from } \\
\text { a leaking tank. }\end{array}$ & None detected \\
\hline $11-10-68$ & $\begin{array}{l}\text { Petrotomics Co. , } \\
\text { Shirley Basin, WY }\end{array}$ & $\begin{array}{l}\text { Solvent extraction } \\
\text { circuit. } \\
\$ 300,000 \text { damage }\end{array}$ & None detected \\
\hline $12-25-68$ & $\begin{array}{l}\text { Atlas Corp., } \\
\text { Moab, UT }\end{array}$ & $\begin{array}{l}\text { Solvent extraction } \\
\text { circuit. Cause } \\
\text { unknown. } \\
\$ 1,000,000 \text { damage }\end{array}$ & None detected \\
\hline $10-23-80$ & $\begin{array}{l}\text { Minerals Exploration, } \\
\text { Sweetwater, WY }\end{array}$ & $\begin{array}{l}\text { Major fire burned } \\
\text { in mill before it } \\
\text { started operation }\end{array}$ & $\begin{array}{l}\text { None. Radioactive } \\
\text { material was } \\
\text { not yet being } \\
\text { processed. }\end{array}$ \\
\hline $1-2-81$ & $\begin{array}{l}\text { Atlas Corp., } \\
\text { Moab, UT }\end{array}$ & $\begin{array}{l}\text { Fire in yellowcake } \\
\text { scrubber stack for } \\
15 \text { min }\end{array}$ & None detected \\
\hline
\end{tabular}


Table 2. Uranium Mill Tailings Releases, 1959-1986

\begin{tabular}{|c|c|c|c|}
\hline Date & Mill & Type of Incident & Release \\
\hline $8-19-59$ & $\begin{array}{l}\text { Union Carbide } \\
\text { Green River, UT }\end{array}$ & $\begin{array}{l}\text { Tailings dam washed } \\
\text { out }\end{array}$ & $\begin{array}{l}\sim 15,000 \mathrm{~T} \text { sands lost to } \\
\text { river in flash floods; no } \\
\text { increase in dissolving Ra } \\
\text { was noted in river. }\end{array}$ \\
\hline $8-22-60$ & $\begin{array}{l}\text { Kerr-McGee } \\
\text { Shiprock, NM }\end{array}$ & $\begin{array}{l}\text { Raffinate pond } \\
\text { dike failure }\end{array}$ & $\begin{array}{l}240,000 \text { gal of raffinate } \\
\text { releases into river } \\
\sim 50 \times 10^{-8} \mu \mathrm{Ci} / \mathrm{ml} \text { Ra- } 226 ; \\
\text { river samples collected } \\
\text { several days after release } \\
\text { showed no increase in } \\
\text { Ra- } 226 \text { background. }\end{array}$ \\
\hline $12-6-61$ & $\begin{array}{l}\text { Union Carbide } \\
\text { Maybel1, CO }\end{array}$ & $\begin{array}{l}\text { Tailings dike } \\
\text { failure }\end{array}$ & $\begin{array}{l}\text { } 500 \mathrm{~T} \text { solids released } \\
\text { from tailings area; } 200 \mathrm{~T} \\
\text { reached unrestricted area; } \\
\text { no liquid reached any } \\
\text { stream. }\end{array}$ \\
\hline $6-11-62$ & $\begin{array}{l}\text { Mines Deve lop- } \\
\text { ment, Inc. } \\
\text { Edgemont, SD }\end{array}$ & $\begin{array}{l}\text { Tailings dike } \\
\text { failure }\end{array}$ & $\begin{array}{l}200 \mathrm{~T} \text { solids washed into } \\
\text { creek and some carried } \\
25 \mathrm{mi} \text { into reservoir. }\end{array}$ \\
\hline $8-17-62$ & $\begin{array}{l}\text { Atlas-Zinc } \\
\text { Minerals } \\
\text { Mexican Hat, UT }\end{array}$ & $\begin{array}{l}\text { Slurry pipeline } \\
\text { rupture }\end{array}$ & $\begin{array}{l}\text { Est. } 280 \mathrm{~T} \text { solids }+240 \mathrm{~T} \\
\text { liquids released from } \\
\text { broken tailings discharge } \\
\text { line into draw } 1.5 \mathrm{mi} \text { from } \\
\text { river. }\end{array}$ \\
\hline $6-16-63$ & $\begin{array}{l}\text { Utah Construction } \\
\text { Riverton, WY }\end{array}$ & $\begin{array}{l}\text { Precautionary } \\
\text { release }\end{array}$ & $\begin{array}{l}\text { Material released by } 2 \mathrm{ft} \\
\text { drainage cut made to prevent } \\
\text { cresting due to heavy rains; } \\
\text { material released below } \\
10 \text { CFR Part } 20 \text { values. }\end{array}$ \\
\hline $11-17-66$ & $\begin{array}{l}\text { VCA } \\
\text { Shiprock, NM }\end{array}$ & $\begin{array}{l}\text { Raffinate line } \\
\text { failure }\end{array}$ & $\begin{array}{l}\text { Est. } 16,000 \text { gals of } 1 \text { iquid } \\
\text { lost because of break in } \\
\text { raffinate } 1 \text { ine; material } \\
\text { spread over } 1 / 4 \text { acre; break } \\
\text { occurred } 1 \mathrm{mi} \text { from river } \\
\text { with some small amount } \\
\text { reaching river. }\end{array}$ \\
\hline $2-6-67$ & $\begin{array}{l}\text { Atlas Corp. } \\
\text { Moab, UT }\end{array}$ & Line failure & $\begin{array}{l}440,000 \text { gal lost; average } \\
\text { Ra- } 226 \text { concentration was } \\
\text { was } 5.5 \times 10^{-8} \mathrm{mCi} / \mathrm{ml} \text {. }\end{array}$ \\
\hline
\end{tabular}


Table 2. (continued)

\begin{tabular}{|c|c|c|c|}
\hline Date & Mill & Type of Incident & Release \\
\hline $7-2-67$ & $\begin{array}{l}\text { Climax Uranium } \\
\text { Grand Junction, } \\
\text { Co }\end{array}$ & $\begin{array}{l}\text { Tailings dike } \\
\text { failure }\end{array}$ & $\begin{array}{l}\text { Dike failure released } \\
1-10 \text { acre-ft of waste } \\
\text { liquid into Colorado River; } \\
\text { no indication that Ra conc. } \\
\text { in river exceeded } 10 \text { CFR } \\
\text { Part } 20 \text { limits. }\end{array}$ \\
\hline $11-23-68$ & $\begin{array}{l}\text { Atlas Corp. } \\
\text { Moab, UT }\end{array}$ & $\begin{array}{l}\text { Slurry pipeline } \\
\text { rupture }\end{array}$ & $\begin{array}{l}35,000 \text { gal of tailings } \\
\text { slurry lost; flowed } 1 / 2 \\
\text { mile to Colorado River; } \\
\text { most solids settled out } \\
\text { in drywash. }\end{array}$ \\
\hline $2-16-71$ & $\begin{array}{l}\text { Petrotomics } \\
\text { Shirley Basin, } \\
\text { WY }\end{array}$ & $\begin{array}{l}\text { Secondary tailings } \\
\text { dike failure }\end{array}$ & $\begin{array}{l}2,000 \text { gal of liquid lost } \\
\text { to unrestricted area; spill } \\
\text { froze in place. }\end{array}$ \\
\hline $3-23-71$ & $\begin{array}{l}\text { Western Nuclear } \\
\text { Jeffrey City, } \\
\text { WY }\end{array}$ & $\begin{array}{l}\text { Tailings line and } \\
\text { dike failure }\end{array}$ & $\begin{array}{l}\text { Break in slurry line caused } \\
\text { a dike failure allowing sand } \\
\text { tails to flow into natural } \\
\text { basin adjacent to tailings } \\
\text { site on licensee's property. }\end{array}$ \\
\hline $2-5-77$ & $\begin{array}{l}\text { United Nuclear- } \\
\text { Homestake } \\
\text { Partners } \\
\text { Grants, NM }\end{array}$ & $\begin{array}{l}\text { Slurry pipeline } \\
\text { rupture }\end{array}$ & $\begin{array}{l}50,000 \text { tons of solids and } \\
\text { slimes and somewhere between } \\
2 \text { million and } 8 \text { million gal } \\
\text { of liquid. All material was } \\
\text { confined to company property. }\end{array}$ \\
\hline $4-77$ & $\begin{array}{l}\text { Western Nuclear, } \\
\text { Inc. } \\
\text { Jeffrey City, WY }\end{array}$ & $\begin{array}{l}\text { Failure of tailings } \\
\text { pond embankment }\end{array}$ & $\begin{array}{l}\sim 2 \text { million gal of liquid } \\
\text { tailings and } 55 \mathrm{yd}^{3} \text { of } \\
\text { solids were released. No } \\
\text { material was released to } \\
\text { unrestricted areas. }\end{array}$ \\
\hline $\begin{array}{l}9-26-77 \\
9-27-77\end{array}$ & $\begin{array}{l}\text { United Nuclear } \\
\text { Church Rock, NM }\end{array}$ & $\begin{array}{l}\text { Release from } \\
\text { tailings slurry } \\
\text { line }\end{array}$ & $\begin{array}{l}\text { Approximately } 1 \text { ton of } \\
\text { solids and } 900 \text { gal of liquid } \\
\text { entered the watercourse. }\end{array}$ \\
\hline $7-16-79$ & $\begin{array}{l}\text { United Nuclear } \\
\text { Church Rock, NM }\end{array}$ & $\begin{array}{l}\text { Tailings dike } \\
\text { failure }\end{array}$ & $\begin{array}{l}100,000,000 \text { gallons of tail- } \\
\text { ings solution and } 1,100 \text { tons } \\
\text { of tailings solids. Most of } \\
\text { the solids were deposited } \\
\text { near the impoundment, but } \\
\text { much solution reached a } \\
\text { river. }\end{array}$ \\
\hline
\end{tabular}

Reference: Regulatory Guide 3.11.1, "Operational Inspection and Surveillance of Embankment Retention Systems for Uranium Mill Tailings." 
Table 3. Accident Source Terms and Doses From Uranium Mill Accidents

\begin{tabular}{|c|c|c|c|c|c|c|c|c|}
\hline \multirow[b]{2}{*}{ Reference } & \multicolumn{2}{|l|}{ Tornado } & \multicolumn{2}{|c|}{ Tailing Pond Release } & \multicolumn{2}{|c|}{$\begin{array}{c}\text { Fire in Solvent } \\
\text { Extraction Circuit }\end{array}$} & \multicolumn{2}{|c|}{$\begin{array}{l}\text { Failure of the Air } \\
\text { Cleaning System Serving the } \\
\text { Yellowcake Drying Area }\end{array}$} \\
\hline & Release & Dose & Release & Dose & Release & Dose & Release & Dose \\
\hline GEIS & $\begin{array}{l}11,400 \mathrm{~kg} \mathrm{U} \text { total } \\
<11,400 \mathrm{~kg} \mathrm{U} \\
\text { respirable }\end{array}$ & $\begin{array}{l}<2.2 \times 10^{-7} \mathrm{rem} \\
\text { to lungs at } 500 \mathrm{~m}\end{array}$ & $\begin{array}{l}1400 \text { tons solid } \\
14,000,000 \text { gal. } \\
\text { liquids }\end{array}$ & $\begin{array}{l}\text { Sma11. Cleanup } \\
\text { assumed }\end{array}$ & $\begin{array}{l}<13 \mathrm{~kg} \mathrm{U} \\
<0.65 \mathrm{~kg} \text { thorium* }\end{array}$ & $\begin{array}{l}<1.36 \mathrm{rem}^{\star} \\
\text { to bone at } \\
500 \mathrm{~m}\end{array}$ & $\begin{array}{l}11 \mathrm{~kg} \text { insoluble } \\
\text { U oxides } \\
\text { over } 8 \text { hours }\end{array}$ & $\begin{array}{l}86 \text { mrem } \\
\text { to } 7 \text { ung } \\
\text { at } 2000 \mathrm{~m}\end{array}$ \\
\hline $\begin{array}{l}\text { Sand Rock } \\
\text { DES }\end{array}$ & $\begin{array}{l}4550 \mathrm{~kg} \mathrm{U} \text { total } \\
<4550 \mathrm{~kg} \mathrm{U} \\
\text { respirable }\end{array}$ & $\begin{array}{l}<1.1 \times 10^{-7} \text { rem } \\
\text { at } 4000 \mathrm{~m} \\
(\max . \text { dose })\end{array}$ & Same as GEIS & - & $<1.1 \mathrm{~kg} \mathrm{U}$ & $\begin{array}{l}10-7 \text { rem } \\
\text { to bone } \\
\text { at } 8000 \mathrm{~m} \\
\text { (nearest } \\
\text { residence) }\end{array}$ & $\begin{array}{l}12 \mathrm{~kg} \text { insoluble } \\
\text { U oxides over } \\
8 \text { hours }\end{array}$ & $\begin{array}{l}10^{-2} \text { rem } \\
\text { to Tung at } \\
8000 \mathrm{~m} \\
\text { (nearest } \\
\text { residence) }\end{array}$ \\
\hline $\begin{array}{l}\text { This } \\
\text { Report }\end{array}$ & - & - & - & - & $1.3 \mathrm{~kg} \mathrm{U}$ & $\begin{array}{l}0.01 \text { to } \\
0.1 \text { rem EDE }\end{array}$ & - & - \\
\hline
\end{tabular}

References

GEIS: "Final Generic Environmental Impact Statement on Uranium Milling," NUREG-0706, Volume 1, pp 7-1 to 7-20, September, 1980.

Sand Rock DES: "Draft Environmental Statement Related to the Operation of Sand Rocks Mill Project," NUREG-0889, pages 5-1 to 5-12, March, 1982.

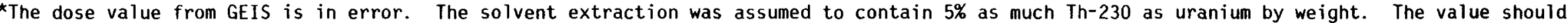
have been $5 \%$ by activity. This error causes the dose to be overestimated by a factor of about 50,000 times. 
of radioactive material promptly drop to very low levels. External exposure is negligible because uranium is a very weak gamma emitter.

Tornadoes could release a larger amount of radioactive material. However, they spread the material so greatly that resulting doses are very small, * as shown in Table 3. Because the doses that would be caused by tornadoes are so much smaller than doses from other accidents, releases and doses due to tornadoes are not discussed further in this analyses.

Tailings pond failures also release a large quantity of material. However, the dose rates are less than $0.1 \mathrm{mR} / \mathrm{hr}$ and radioactive material concentrations are so low that prompt emergency action is not needed to prevent anyone's dose from exceeding the EPA's protective action guides.

Thus we conclude that a fire in the solvent extraction circuit is the accident of greatest significance for emergency preparedness. We assume the release from the building is $1.3 \mathrm{~kg}$ of uranium. The $1.3 \mathrm{~kg}$ release is based on $0.1 \%$ of the material in process becoming airborne and escaping from the building. Experiments on releases of uranium in a kerosene fire showed average releases of $0.025 \%$ when the residue is not heated with a propane torch after dryness occurs.** Due to licensing policy requiring automatic fire detection and supression systems*** (such as automatic sprinklers, foam, or halon systems) significant heating beyond dryness would not be expected. 0ther experiments showed similarly low releases. $\dagger$ The uranium would be in insoluble form (solubility class $Y$ ) because a large kerosene fire would produce temperatures exceeding $400^{\circ} \mathrm{C}$, the temperature at which the uranium should form insoluble oxides.**** The uranium may be class $Y$ if the fire completely oxidizes the

*NUREG-0706, Volume 1, "Final Generic Environmental Impact Statement on Uranium Milling," September, 1980, p. 7-4.

**Jofu Mishima and Lyle Schendiman, "Interim Report: The Fractional Airborne Release of Dissolved Radioactive Materials During the Combustion of 30 Percent Normal Tributyl Phosphate in a Kerosene-Type Diluent," BNWL-B-274, Pacific Northwest Laboratory, 1973.

***Regulatory Guide 8.31, "Information Relevant to Ensuring that Occupational Radiation Exposures at Uranium Mills Will Be as Low as Is Reasonably Achievable," Section C.3.4.

†D. Whitney Tharin, Jr., "Burning of Radioactive Process Solvent," Savannah River Laboratory Report DP-942, Aiken, South Carolina, 1965.

****R. C. Merritt, The Extractive Metallurgy of Uranium, Colorado School of Mines Research Institute, pp. 252-4, 1971. 
soluble class $D$ uranium in the solvent extraction tanks and converts it to insoluble uranium.

This source term of $1.3 \mathrm{~kg}$ of uranium is also considered to be suitable for "in-situ" solution mining. Some "in situ" mining processes use solvent extraction processes similar to those in uranium mills. More severe accidents than described above were not identified for "in-situ" mining.

\subsubsection{Calculations of Doses}

A $1.3 \mathrm{~kg}$ release of natural uranium due to a fire at an uranium mill could result in a potential dose of 0.1 rem effective dose equivalent during adverse weather $(F, 1 \mathrm{~m} / \mathrm{s})$ or 0.01 rem during typical weather $(D, 4.5 \mathrm{~m} / \mathrm{s})$. Assumptions were that the building size was $10 \mathrm{~m}$ high by $25 \mathrm{~m}$ wide, the release height was ground level, and the release duration was 30 minutes. The factors for determining effective dose equivalent from ICRP Publication 30 for a particle size of 1 micron AMAD and class $Y$ solubility are: $1.31 \times 10^{8} \mathrm{rem} / \mathrm{Ci}$ for $\mathrm{U}-234,1.21$ $\times 10^{8} \mathrm{rem} / \mathrm{C} i$ for $U-235$, and $1.17 \times 10^{8} \mathrm{rem} / \mathrm{Ci}$ for $U-238$. If 1 curie of uranium is composed of $U-234, U-235$, and $U-238$ in their naturally occurring proportions, the dose conversion factor is $1.24 \times 10^{8} \mathrm{rem} / \mathrm{C}$.

The calculated dose from this accident is small ( 0.1 rem or less) because of the very low specific activity of the uranium and the low volatility of the uranium compounds, which causes a low release fraction.

Low release fractions are the reason why no offsite ground contamination was ever detected due to the fires listed in Table 1.

\subsubsection{Implications for Emergency Preparedness}

On the basis of the very low doses calculated, the staff concludes that there is no need for offsite emergency protective actions on the part of the public at uranium mills or for "in-situ" mining.

The staff concludes that no credible accident would justify emergency protective actions because radiation doses to the public offsite from an accident would be below the EPA's protective action guides. Also, the quantity of uranium inhaled is below the quantity where chemical toxicity effects are 
observed.* Thus, neither radiation doses nor chemical toxicity from licensed materials is a concern with respect to the need for prompt protective actions.

In the event of such a fire, the licensee would be required by existing NRC regulations to take certain actions. Among these, the licensee would be required by $\$ 20.201$ (b) to conduct surveys (offsite if appropriate) to determine whether the NRC's limits on radioactivity in effluents to unrestricted areas in \$20.106 were exceeded. A major fire would also require immediate notification of NRC by telephone and telegraph (\$20.403). If appropriate, the NRC could elect to immediately send an inspector to the site to make any necessary radiation measurements or evaluate the situation.

With respect to tailing dam failures, rapid emergency response is not needed to avoid doses exceeding protection action guides because dose rates at a spill site are very low. An appropriate response is to monitor drinking water, especially for radium-226, to be sure that drinking water standards are met. Gamma ray monitoring of the ground is also appropriate to determine where the tailings have been deposited. However, ground contamination presents little immediate hazard to the public because the gamma dose rates are low. Gamma dose rates in contact with tailings should be less than $0.1 \mathrm{mR} / \mathrm{hr}$. Since the EPA's protective action guides would not be exceeded, a rapid emergency response is not needed. A clean-up of the spilled tailings would be expected, but this could be done effectively without preexisting emergency preparedness.

\subsection{3 $\mathrm{UF}_{6}$ Conversion Plants}

Conversion plants convert yellowcake shipped from uranium mills into uranium hexafluoride $\left(U F_{6}\right)$. Heated liquid $U F_{6}$ is put into 10-ton or 14-ton cylinders. The cylinders are cooled for several days until the UF 6 solidifies. Eventually, the filled cylinders are shipped to enrichment plants to enrich the uranium in U-235. There are two NRC-1icensed conversion plants: Kerr-McGee in Oklahoma and Allied Chemical in Illinois.

The uranium is handled in many different chemical forms in $\mathrm{UF}_{6}$ conversion plants, but the $U_{6}$ itself is the only chemical form of uranium that is readily dispersible. For example, the dispersibility of yellowcake is essentially the

\footnotetext{
*R. A. Just and V. S. Emler, "Generic Report of Health Effects for the U.S. Gaseous Diffusion Plants," DOE Report K/D 5050, Section VIII, Part 1, page 6, 1984.
} 
same as that of yellowcake at uranium mills. Accidents involving yellowcake were previously discussed and found not to require offsite emergency preparedness.

The release of $U_{6}$ in significant quantity is possible because $U_{6}$ is volatile above room temperature. The $U_{6}$ released will react with water in the air as follows:

$$
\mathrm{UF}_{6}+2 \mathrm{H}_{2} \mathrm{O}=\mathrm{UO}_{2} \mathrm{~F}_{2}+4 \mathrm{HF}+52.2 \mathrm{kcal} / \mathrm{mole} \mathrm{m}^{\star}
$$

The $\mathrm{UO}_{2} \mathrm{~F}_{2}$ forms a particulate, very soluble in the lungs, which will be carried away by wind and will settle onto the ground. The HF is a corrosive acid vapor that can severely harm the lungs if sufficiently concentrated. The release of $1 \mathrm{~kg}$ of $U F_{6}$ combining with $0.1 \mathrm{~kg}$ of water results in release of $0.88 \mathrm{~kg}$ of $\mathrm{UO}_{2} \mathrm{~F}_{2}$ (which contains $0.68 \mathrm{~kg}$ of uranium) and $0.23 \mathrm{~kg}$ of $\mathrm{HF}$.

\subsubsection{Accident History}

Table 4 lists significant releases of UF 6 that have occurred from all types of facilities, not just conversion plants. There have been many releases of $U F_{6}$. The releases have caused at least three prompt fatalities and several injuries. The significant $U F_{6}$ releases have consistently been with $U_{6}$ heated above its melting point $\left(65^{\circ} \mathrm{C}\right)$. The releases have generally been fairly rapid--lasting from less than a minute to an hour. The plumes, where they are highly concentrated, have been visible and immediately irritating to the lungs. The escape of $U_{6}$ can be diminished greatly if the leak can be sprayed with water.

Inhalation of uranium due to a $U_{6}$ release can be verified by measurements of uranium concentrations in urine taken within 48 hours of the exposure. The uranium from $U_{6}$ has a biological half-life for expulsion via the urine of 4 to 6 hours.** Workers exposed to high concentrations have suffered edema of the lungs, presumably from exposure to $\mathrm{HF}$, and kidney damage due to heavy metal

\footnotetext{
*Minton Kelly, Oak Ridge National Laboratory, Sept. 1983.

**M.W. Babcock and R. C. Heatherton, "Bioassay Aspects of a UF 6 Fume Release," Proceedings of the 12th Annual Bio-Assay and Analytical Chemistry Meeting, AEC Report CONF-661018, 1966, pp 147-159.
} 
Table 4. Accidents Involving $\mathrm{UF}_{6}$ Releases through 1986

\begin{tabular}{|c|c|c|c|c|}
\hline Date & Facility & $\begin{array}{l}\text { Type of } \\
\text { facility }\end{array}$ & $\begin{array}{l}\text { Quantity of } \\
\text { UF }_{6} \text { released }\end{array}$ & Cause and consequence \\
\hline $9-2-44^{*}$ & $\begin{array}{l}\text { Philadelphia } \\
\text { Naval Yard }\end{array}$ & $\begin{array}{l}R \& D \text { for } \\
\text { thermal } \\
\text { diffusion }\end{array}$ & $\begin{array}{l}200 \mathrm{~kg} \\
\text { accompanied } \\
\text { with live } \\
\text { steam }\end{array}$ & $\begin{array}{l}\text { Rupture or explosion } \\
\text { of large tank. Two } \\
\text { workers killed. Three } \\
\text { other workers seriously } \\
\text { injured, } 13 \text { others } \\
\text { less seriously injured } \\
\text { or not injured. }\end{array}$ \\
\hline Pre 1949 & AEC facility & $\begin{array}{l}\text { Not } \\
\text { identified }\end{array}$ & $\begin{array}{l}\text { Believed to } \\
\text { be } 13 \mathrm{~kg}\end{array}$ & $\begin{array}{l}\text { Sudden leak in a hot } \\
\text { cylinder. One worker } \\
\text { received injury to } \\
\text { respiratory tract, } \\
\text { eyes, and kidneys. }\end{array}$ \\
\hline $5-10-60$ & $\begin{array}{l}\text { Babcock \& } \\
\text { Wilcox, } \\
\text { Apollo, PA }\end{array}$ & $\begin{array}{l}\text { Fuel } \\
\text { fabrication }\end{array}$ & $\begin{array}{l}\text { Not } \\
\text { reported }\end{array}$ & $\begin{array}{l}\text { Leak in heat exchanger } \\
\text { allowed } \mathrm{UO}_{2} \mathrm{~F}_{2} \text { to escape } \\
\text { to river water. } 60 \times \\
\text { MPC at discharge point. }\end{array}$ \\
\hline $11-17-60$ & $\begin{array}{l}\text { Union Carbide, } \\
\text { Oak Ridge, TN }\end{array}$ & $\begin{array}{l}\text { Uranium } \\
\text { enrichment }\end{array}$ & $\begin{array}{l}\text { Not } \\
\text { reported }\end{array}$ & $\begin{array}{l}\text { Rupture of } 10 \text {-ton } \\
\text { cyl inder. }\end{array}$ \\
\hline $5-25-62$ & $\begin{array}{l}\text { Nuclear Fuel } \\
\text { Services, } \\
\text { Erwin, TN }\end{array}$ & $\begin{array}{l}\text { Fuel } \\
\text { fabrication } \\
\text { metal }\end{array}$ & $\begin{array}{l}15 \mathrm{~kg} \mathrm{HEU} \text { in } \\
5 \mathrm{~min} .6 \mathrm{~kg} \\
\text { recovered in } \\
\text { plant }\end{array}$ & $\begin{array}{l}\text { An overheated } 15-\mathrm{kg} \\
\text { cylinder ruptured and } \\
\text { released its contents } \\
\text { in the building. }\end{array}$ \\
\hline $3-20-64$ & $\begin{array}{l}\text { Nuclear Fuel } \\
\text { Services, } \\
\text { Erwin, TN }\end{array}$ & $\begin{array}{l}\text { Fuel } \\
\text { fabrication } \\
\text { metal }\end{array}$ & $\begin{array}{l}1 \mathrm{~kg} \text { in } 2 \text { hrs. } \\
\text { Half recovered } \\
\text { onsite }\end{array}$ & Overpressure burst tube \\
\hline $2-14-66$ & $\begin{array}{l}\text { National } \\
\text { Lead, } \\
\text { Fernald, } \mathrm{OH}\end{array}$ & $\begin{array}{l}\text { Feed } \\
\text { material } \\
\text { production }\end{array}$ & $\begin{array}{l}2300 \mathrm{~kg} \text { in } \\
1 \mathrm{hr} \text {. Much } \\
\text { absorbed by } \\
\text { water spray }\end{array}$ & $\begin{array}{l}\text { Operator accidentally } \\
\text { removed valve on a hot } \\
\text { 10-ton cylinder, deve- } \\
\text { loped lung edema, } \\
\text { hospitalized } 6 \text { days. } \\
\text { No observed injury to } \\
\text { kidney. }\end{array}$ \\
\hline $6-29-67$ & $\begin{array}{l}\text { Kerr-McGee, } \\
\text { Gore, OK }\end{array}$ & $\begin{array}{l}\text { UF }_{6} \\
\text { conversion }\end{array}$ & $\begin{array}{l}45 \mathrm{~kg} \text { in } \\
15-20 \mathrm{~min}\end{array}$ & $\begin{array}{l}\text { Gasket leaked due to } \\
\text { overheating. }\end{array}$ \\
\hline $7-19-68$ & $\begin{array}{l}\text { Kerr-McGee } \\
\text { Crescent, OK }\end{array}$ & $\begin{array}{l}\text { Fuel } \\
\text { fabrication }\end{array}$ & $\begin{array}{l}45 \mathrm{~kg} \text { of } 1.6 \% \\
\text { enriched } U \\
\text { in } 15-20 \mathrm{~min}\end{array}$ & $\begin{array}{l}\text { Valve accidentally left } \\
\text { open during heating. }\end{array}$ \\
\hline
\end{tabular}

*Ronald Kathren and Robert Moore, "Acute Accidental Inhalation of U : A 38-year follow-up," Health Physics, 51, 609, 1986. 
Table 4. (continued)

\begin{tabular}{|c|c|c|c|c|}
\hline Date & Facility & $\begin{array}{l}\text { Type of } \\
\text { facility }\end{array}$ & $\begin{array}{l}\text { Quantity of } \\
\mathrm{UF}_{6} \text { released }\end{array}$ & Cause and Consequence \\
\hline $11-12-68$ & $\begin{array}{l}\text { Allied } \\
\text { Chemical, IL }\end{array}$ & $\begin{array}{l}\mathrm{UF}_{6} \\
\text { conversion }\end{array}$ & $43 \mathrm{~kg}$ & Valve failure \\
\hline $5-2-73$ & $\begin{array}{l}\text { Goodyear } \\
\text { Atomic } \\
\text { Oak Ridge, TN }\end{array}$ & $\begin{array}{l}\text { UF } \\
\text { processing }\end{array}$ & $\begin{array}{l}100 \mathrm{~kg} \text { in } \\
20 \text { min } \\
\text { (inside) }\end{array}$ & $\begin{array}{l}\text { Worker broke valve on } \\
10 \text {-ton cylinder. }\end{array}$ \\
\hline $4-20-74$ & $\begin{array}{l}\text { Numec, } \\
\text { Apollo, PA }\end{array}$ & $\begin{array}{l}\text { Mixed oxide } \\
\text { fuel } \\
\text { fabrication }\end{array}$ & $\begin{array}{l}6 \mathrm{~kg}, \text { slightly } \\
\text { enriched }\end{array}$ & \\
\hline $12-2-76$ & $\begin{array}{l}\text { Exxon Nuclear, } \\
\text { Richland, WA }\end{array}$ & $\begin{array}{l}\text { Fuel } \\
\text { fabrication }\end{array}$ & Smal1 & $\begin{array}{l}\text { Worker disconnected } \\
\text { line but had forgotten } \\
\text { to close valve. }\end{array}$ \\
\hline $3-7-78$ & $\begin{array}{l}\text { Portsmouth } \\
\text { Gaseous } \\
\text { Diffusion } \\
\text { Plant, } \mathrm{OH}\end{array}$ & $\begin{array}{l}\text { Enrichment } \\
\text { plant }\end{array}$ & $\begin{array}{l}9500 \mathrm{~kg} \\
\text { in } 1 / 2 \text { to } \\
1 \text { hour }\end{array}$ & $\begin{array}{l}\text { Rupture of dropped hot } \\
14-\text { ton } \mathrm{UF}_{6} \text { cylinder. }\end{array}$ \\
\hline $12-3-78$ & GE & $\begin{array}{l}\text { Fuel } \\
\text { fabrication }\end{array}$ & not known & Block valve opened \\
\hline $8-7-79$ & $\begin{array}{l}\text { NFS, Erwin } \\
\text { TN }\end{array}$ & $\begin{array}{l}\text { Fuel } \\
\text { fabrication }\end{array}$ & $<3 \mathrm{~kg}$ & $\begin{array}{l}\text { Accidental venting of } \\
\text { cylinder to stack. }\end{array}$ \\
\hline $5-20-80$ & $\mathrm{GE}$ & $\begin{array}{l}\text { Fuel } \\
\text { fabrication }\end{array}$ & $<1 \mathrm{~kg}$ & Pipe flange failure \\
\hline $9-15-81$ & $\mathrm{GE}$ & $\begin{array}{l}\text { Fuel } \\
\text { fabrication }\end{array}$ & $<<74 \mathrm{~kg}$ & Gasket leak \\
\hline $10-12-81$ & $\begin{array}{l}\text { NFS, Erwin, } \\
\text { TN }\end{array}$ & $\begin{array}{l}\text { Fuel } \\
\text { fabrication }\end{array}$ & $\begin{array}{l}0.05 \text { to } 0.1 \\
\mathrm{~kg}, \mathrm{HEU}\end{array}$ & $\begin{array}{l}\text { Release via main } \\
\text { scrubber stack. }\end{array}$ \\
\hline $2-25-82$ & Exxon & $\begin{array}{l}\text { Fuel } \\
\text { fabrication }\end{array}$ & $<<25 \mathrm{~kg}$ & Gasket leak \\
\hline $12-83$ & $\begin{array}{l}\text { Edlow Inter- } \\
\text { national, East } \\
\text { St. Louis, IL }\end{array}$ & Warehouse & None & Fire in warehouse. \\
\hline $1-4-86$ & $\begin{array}{l}\text { Sequoyah } \\
\text { Fuels } \\
\text { Corp., Gore } \\
\text { OK }\end{array}$ & $\begin{array}{l}\mathrm{UF}_{6} \\
\text { conversion }\end{array}$ & $\begin{array}{l}14,000 \mathrm{~kg} \\
\text { in less than } \\
\text { a minute. } \\
\text { Between } 10 \% \\
\text { and } 50 \% \text { of the } \\
\text { uranium became } \\
\text { airborne }\end{array}$ & $\begin{array}{l}\text { Heating of overfilled } \\
\text { cylinder. One worker } \\
\text { killed. Several injurec } \\
\text { from HF. }\end{array}$ \\
\hline
\end{tabular}


poisoning from uranium. At least two workers were killed. Persons injured or killed in this manner have all been workers in a room working close to a $U_{6}$ cylinder.

Two of the cases involving the most serious exposures were reported by Howland.* He reported two fatalities, four serious injuries, and slight injury to 13 other people. One of the fatalities showed by autopsy roughly $1000 \mathrm{mg}$ of uranium in the lungs. Howland concluded that the most serious injuries (observed on the skin, eye, mucous membrane of the upper respiratory tract, esophagus, larynx, and bronchi) were all caused by the action of the fluoride ion on the exposed tissues. Uranium produced transient urinary-tract changes. A long-term follow-up of three of the workers was reported by Kathren and Moore $f$. The three men were estimated to have initial depositions in the lung of 40 to $50 \mathrm{mg}$ of uranium. Medical and health physics examinations of two of the men 38 years after the accident revealed no detectable deposition of uranium nor any physical injury or changes attributable to uranium exposure. The conclusion is that HF and uranium both have adverse effects, but that the HF effects are the more severe.

In the National Lead-Fernald accident, one worker suffered lung edema, presumably from exposure to $\mathrm{HF}$.** No injury to his kidneys was observed. He excreted in urine over $1 \mathrm{mg}$ of uranium in the first two days after the accident, suggesting a total intake of roughly 2 to $3 \mathrm{mg}$ of uranium.

The largest release of UF $_{6}$ occurred in 1986 when a cylinder filled with $U_{6}$ beyond its 14-ton capacity ruptured while being heated at Sequoyah Fuels Corporation in Gore, Oklahoma. Heating an overfilled cylinder was prohibited by company procedures and the NRC license and was widely recognized in the industry as a dangerous and unacceptable practice. The cylinder ruptured because of hydrostatic pressure. The pressure was caused because UF 6 expands significantly when the solid melts and becomes a liquid, but there was not enough room in the cylinder for this expansion. There was not enough room because the cylinder had been overfilled.

*Joe W. Howland, "Studies on Human Exposures to Uranium Compounds," in Pharmacology and Toxicology of Uranium Compounds, edited by Carl Voegtlin and Harold Hodge, McGraw-Hil1, New York, 1949, p 993.

$\ddagger$ Kathren and Moore, op. cit.

**Babcock and Heatherton, op. cit. 
The rupture was about four feet long and most the contents, approximately $14,000 \mathrm{~kg}$, escaped in less than a minute. Of the uranium that escaped the cylinder, most was later found to be on the ground near the release point. The company estimated that 35 percent of the uranium could not be found near the release point, but other estimates were that 50 percent escaped. Thus, the amount of uranium that became airborne would be between about $3300 \mathrm{~kg}$ and $4700 \mathrm{~kg}$.

One worker was killed because of pulmonary edema caused by HF. Several others experienced skin burns, irritation to the eyes and mucous membranes, and respiratory tract irritation (Reference: NUREG-1189). No symptoms were found among people exposed offsite.

Bioassay results for 36 workers showed an average uranium intake of about $6.5 \mathrm{mg}$ and a maximum intake of about $28 \mathrm{mg}$. Nine of the workers were exposed to uranium in excess of $\mathrm{NRC}^{\prime} \mathrm{s}$ regulatory limit ( $9.6 \mathrm{mg}$ intake within a week), but no symptoms of kidney injury were observed.

Another large release of $U_{6}$ was the 1978 accident at the Portsmouth, Ohio gaseous diffusion plant. In this accident a heated thin-walled cylinder containing 14 (short) tons of natural $\mathrm{UF}_{6}$ was dropped 8 to 10 inches and ruptured below the liquid level.* Within one hour, about $9500 \mathrm{~kg}$ of $\mathrm{UF}_{6}$ escaped. This is equal to about $6400 \mathrm{~kg}$ of uranium. The release was outdoors. The air temperature was $32^{\circ} \mathrm{F}$, the wind speed was 2 meters $/ \mathrm{sec}$, and a mixture of snow and freezing rain was falling. Snow covered the ground. About $550 \mathrm{~kg}$ of uranium were recovered on the ground afterwards. Agglomeration is likely to have increased the settling. About $4800 \mathrm{~kg}$ of uranium (75\% of the release) were estimated to have become airborne and dissipated in the air, much thereby leaving the site. The site boundary in the downwind direction was at a distance of $2.2 \mathrm{~km}$.

\footnotetext{
*"Investigation of Occurrence Involving Release of Uranium Hexafluoride from a Fourteen-Ton Cylinder at the Portsmouth Gaseous Diffusion Plant on March 7, 1978," DOE Report ORO-757, June, 1978.
} 
Water samples from a drainage ditch located near the release had a peak uranium concentration of $450 \mathrm{mg} / 1,10$ times the NRC's radiological limit for water to be released to unrestricted areas.*

The reported environmental effects were minimal. Workers who drove through the plume showed no detectable uranium in samples of their urine. Significant ground and water contamination were confined to distances of a few hundred yards from the release point. Airborne concentrations at the site boundary $(2.2 \mathrm{~km})$ were calculated to be not high enough to be harmful for brief exposures.

Another large release of $U_{6}$ occurred in France in $1977 . \dagger$ As the result of a handling error a valve ruptured on a container heated to $90-95^{\circ} \mathrm{C}$. The $\mathrm{UF}_{6}$ immediately started to spill out onto the ground. The liquid flow lasted 10 to 15 minutes until the level of liquid in the container had fallen below the valve opening. Then $U F_{6}$ continued escaping as a gas until the valve was plugged with a wooden peg 30 minutes after the rupture. Of the $8800 \mathrm{~kg}$ of liquid $U_{6}$ in the container, $7100 \mathrm{~kg}$ escaped.

Water and carbon dioxide were used to prevent the escaped $\mathrm{UF}_{6}$ from becoming airborne. However, $330 \mathrm{~kg}$ of uranium and $1600 \mathrm{~kg}$ of HF were not recovered. Thus $7 \%$ of the uranium and $98 \%$ of the HF that escaped the container apparently became airborne. Weather conditions favored rapid dilution. It was a warm and sunny afternoon with a windspeed of $9 \mathrm{~m} / \mathrm{s}$.

The French workplace 1 imit for HF of $2.4 \mathrm{mg} / \mathrm{m}^{3}$ was exceeded up to a distance of 1200 meters. Ground contamination by uranium of up to $10 \mathrm{mg} / \mathrm{m}^{2}$ was observed up to 600 meters. The area on which virtually all the solid uranium compounds settled did not exceed $1000 \mathrm{~m}^{2}$.

No injuries were observed. Urine samples were taken from 449 people. Two workers excreted more than $0.5 \mathrm{mg}$ during the first day, but no physiological symptoms were observed. No symptoms of the HF exposure were observed.

\footnotetext{
*The NRC limit for water in unrestriced areas in 10 CFR Part 20, Appendix B is $3 \times 10^{-5}$ microcuries $/ \mathrm{ml}$. Using the specific activity of natural uranium of $6.77 \times 10^{-7}$ microcuries/microgram, the effluent water standard is equivalent to $44 \mathrm{milligrams/liter.}$

$\lceil$ A.J. Docouret, "An Experience of Accidental Release of UF 6 , Comurtex Plant, Pierrelatte, France.
} 
In addition to gaseous $\mathrm{UF}_{6}$ releases, conversion plants have released uranium to rivers. On Dec. 1, 1978 the Kerr-McGee conversion plant accidentally released $750 \mathrm{~kg}$ of natural uranium in the form of uranyl nitrate into a river. The liquid released had a uranium concentration of 1.4 times the MPC for water, which would then be diluted by the river water.

\subsubsection{Accident Source Terms}

The NRC staff, Sutter at Pacific Northwest Laboratory, and M. Simon-Tov* at Oak Ridge National Laboratory have recently analyzed potential accidents at $\mathrm{UF}_{6}$ conversion plants to estimate potential releases of $\mathrm{UF}_{6}$.

The largest release postulated by the NRC staff is contained in an Environmental Impact Appraisal for the Allied Chemical conversion plant.** The NRC staff assumed that the largest release of $U_{6}$ would be caused by the rupture of a heated 14-ton cylinder. The staff assumed that $9500 \mathrm{~kg}$ of $\mathrm{UF}_{6}$ would escape and that the material would hydrolyze. As a result, $4800 \mathrm{~kg}$ of natural uranium would be released with the chemical form $\mathrm{UO}_{2} \mathrm{~F}_{2}$, a highly soluble compound.

Sutter*** considered a number of possible accidents. These include:

1. The rupture of two $14-$ ton $U_{6}$ cylinders outdoors in conjunction with a fire fed by 100 gallons of gasoline due to a truck crash

2. A leak of $U_{6}$ from a pipe

3. A tornado strike

4. Fires

5. Chemical explosions

6. Natural gas explosions

The accident determined by Sutter to cause the most significant release is the rupture of two 14-ton $U F_{6}$ cylinders along with a gasoline fire. The initiation is assumed to be a truck accident in which the truck hits the

\footnotetext{
*M. Simon-Tov et al., "Scenarios and Analytical Methods for UF 6 Releases at NRC-Licensed Fuel Cycle Facilities," NUREG/CR-3139, 1984.

**Environmental Impact Appraisal for Renewal of Source Material License, No. SUB-526, Allied Chemical Company UF 6 Conversion Plant, Office of Nuclear Material Safety and Safeguards, NUREG-1071, May, 1984, page 4-28. ***S.L. Sutter, et al., op. cit.
} 
cylinders, ruptures its gas tank, and catches on fire. A total release of up to $3800 \mathrm{~kg}$ of $U_{6}$ was calculated. The amount of material that could be released is limited by the amount of heat available to vaporize the solid $U_{6}$. Heat required to raise the temperature of the cylinder and $U_{6}$ is neglected. If the $U_{6}$ cylinder is not ruptured, the heat is sufficient to raise the temperature of the $U F_{6}$ from 20 to $100^{\circ} \mathrm{F}$. The pressure produced would not be enough to rupture the cylinder.

Simon-Tov's work was directed toward determining accident scenarios and analysis methods for $U_{6}$ releases. His work is the most recent and most comprehensive. Twenty-five release scenarios are described in his report (Chapter 5). The scenario most appropriate for this analysis is the rupture of a heated liquid-filled cylinder outdoors. At a temperature of $100^{\circ} \mathrm{C}$, $57 \%$ of the liquid $\mathrm{UF}_{6}$ could be vaporized. At $120^{\circ} \mathrm{C}$, $65 \%$ could be vaporized (Figure 11, page 58). The most important parameter for determining the release is the temperature of the cylinder. Thus the largest release is from a cylinder just-filled. Analyses of plausibile fire scenarios involving cooled cylinders show that the $U_{6}$ cannot be heated sufficiently to cause as large a release as from a hot cylinder.

For the purpose of this regulatory analysis, the release to be evaluated for $U_{6}$ conversion plants will be one similar to the ones that occurred at the Portsmouth gaseous diffusion plant and the Sequoyah conversion plant. Those accidents involved the ruptures of hot 14-ton $\mathrm{UF}_{6}$ cylinders outdoors. At Portsmouth, there was a release of $9500 \mathrm{~kg}$ of $U_{6}$ (equivalent to $6400 \mathrm{~kg}$ of natural uranium). It is assumed that $4800 \mathrm{~kg}$ of natural uranium becomes airborne and the remainder settles on the ground due to agglomeration and impaction. At Sequoyah, the amount of uranium becoming airborne was probably between $3300 \mathrm{~kg}$ and $4700 \mathrm{~kg}$. A Portsmouth release was calculated by $W$. Reid Williams as likely to occur in about 15 minutes. There would be no advance warning. Because the release is assumed to be outdoors, no automatic detection or alarm system would detect the release. Rather, plant personnel are assumed to detect the release and then take emergency measures.

The plume would be readily detectable to the human senses because of the $H F$ and its resulting irritation. Therefore no monitoring instruments are needed to detect high concentrations. 


\subsubsection{Calculations of Doses}

The release of $\mathrm{UF}_{6}$ presents a chemical rather than radiological hazard. Exposures lethal due to uranium chemical toxicity or HF burns on lung tissue would not result in radiation doses exceeding 1 rem effective dose equivalent. Therefore, radiation doses are not calculated. The release assumed is the escape of $9500 \mathrm{~kg}$ of $\mathrm{UF}_{6}$ in 15 minutes due to the rupture outdoors of a heated 14-ton cylinder. The mass of uranium in $9500 \mathrm{~kg}$ of $\mathrm{UF}_{6}$ is $6400 \mathrm{~kg}$. Some of the uranium will be removed from the air initially by agglomeration and impaction. We assume $4800 \mathrm{~kg}$ of uranium becomes airborne. The corresponding mass of $\mathrm{HF}$ is $1620 \mathrm{~kg}$.

Intakes are calculated for atmospheric stability class $F$ with a wind speed of $1 \mathrm{~m} / \mathrm{s}$ as well as stability Class $D$ with wind speed of $4.5 \mathrm{~m} / \mathrm{s}$. The plume is assumed initially to have a centerline near ground level. The heat from the chemical reaction of $\mathrm{UF}_{6}$ combining with the moisture in the air will cause the plume to become buoyant. Calculations by W. Reid Williams indicate the plume would lift off within 20 to 30 meters and a plume centerline height of about 20 meters would be obtained within 200 to 300 meters. Thus, we assume a plume centerline height of 20 meters.

The equation for uranium intake $I$ is:

$$
I=Q \times B \times \frac{X}{Q}
$$

where $Q=$ the released quantity $(4800 \mathrm{~kg})$,

$B=$ the breathing rate $\left(2.66 \times 10^{-4} \mathrm{~m}^{3} / \mathrm{s}\right)$, and $\chi / Q=$ the atmospheric dispersion value from Figure 1 . 
Uranium intake due to the airborne release of $4800 \mathrm{~kg}$ of uranium

\begin{tabular}{ccl}
\hline & \multicolumn{2}{c}{ Uranium intake (mg) } \\
\cline { 2 - 3 } $\begin{array}{l}\text { Distance } \\
\text { (meters) }\end{array}$ & $\begin{array}{l}\text { F, } 1 \mathrm{~m} / \mathrm{s} \\
\text { buoyant }\end{array}$ & $\begin{array}{l}\text { D, } 4.5 \mathrm{~m} / \mathrm{s} \\
\text { buoyant }\end{array}$ \\
\hline 200 & 6 & 53 \\
300 & 46 & 59 \\
500 & 110 & 40 \\
700 & 110 & 28 \\
1,000 & 92 & 17 \\
1,500 & 62 & 10 \\
2,000 & 44 & 6 \\
5,000 & 11 & 1.6 \\
10,000 & 3 & 0.5 \\
15,000 & 1 & 0.3 \\
20,000 & 0.6 & 0.2 \\
\hline
\end{tabular}

The exposure to concentrations of HF can be calculated similarly. Exposures due to the airborne release of $1620 \mathrm{~kg}$ of HF are shown below.

$\mathrm{HF}$ exposure due to the airborne release of $1620 \mathrm{~kg}$ of $\mathrm{HF}$

\begin{tabular}{ccc}
\hline & \multicolumn{2}{c}{ HF exposure $\left(\mathrm{mg} / \mathrm{m}^{3}\right)$} \\
\cline { 2 - 3 } $\begin{array}{l}\text { Distance } \\
\text { (meters) }\end{array}$ & $\begin{array}{c}\text { F, 1 m/s } \\
\text { buoyant }\end{array}$ & $\begin{array}{l}\text { D, } 4.5 \mathrm{~m} / \mathrm{s} \\
\text { buoyant }\end{array}$ \\
\hline 200 & 9 & 77 \\
300 & 68 & 86 \\
500 & 160 & 59 \\
700 & 160 & 41 \\
1,000 & 140 & 25 \\
1,500 & 92 & 14 \\
2,000 & 65 & 9 \\
5,000 & 16 & 2.3 \\
10,000 & 5 & 0.8 \\
15,000 & 1.8 & 0.4 \\
20,000 & 0.9 & 0.3
\end{tabular}




\subsubsection{Implications for Emergency Preparedness}

of all the accidents considered in this Regulatory Analysis, the rupture of a heated 14-ton cylinder of $\mathrm{UF}_{6}$ is clearly and by far the most hazardous to people offsite. The corrosive effects of exposure to HF and heavy metal poisoning due to uptake of uranium are discussed separately below.

Heavy metal poisoning: We consider the best estimates of the health effects of uranium intake to be those in two DOE reports* based on the work of a panel of experts on uranium toxicity. The effects are summarized below:

\begin{tabular}{lc} 
Health Effect & Intake $(\mathrm{mg})$ \\
\cline { 2 - 2 } & 243 \\
50\% Lethality & 45 \\
Permanent damage & 8.6 \\
Renal effect (transient) & 4.5 \\
No effect &
\end{tabular}

It is not likely from the calculated results that lethal intakes are actually plausible for outdoor releases of $\mathrm{UF}_{6}$. In order to calculate lethal intakes it is necessary to assume little or no buoyancy, which is believed to be incorrect, and little or no effort on the part of the exposed individual to escape the plume, which may not be a reasonable assumption. We conclude that lethal intakes of uranium by people offsite are not really plausible under realistic conditions.

Permanent kidney damage, on the other hand, may be possible. From the intakes calculated above permanent kidney damage could occur as far as $2000 \mathrm{~m}$ ( $1.2 \mathrm{miles}$ ) under very adverse weather $(F, 1 \mathrm{~m} / \mathrm{s}$ ) and no attempt to escape the plume, Under more typical conditions $(D, 4.5 \mathrm{~m} / \mathrm{s}$, some buoyancy, and attempted escape) permanent kidney damage would not be expected offsite.

Transient kidney effect appears to be quite plausible. Under highly adverse conditions ( $F, I \mathrm{~m} / \mathrm{s}$ ) it might be possible as far as five miles away. Under more typical conditions ( $D, 4.5 \mathrm{~m} / \mathrm{s}$ and some escape attempt) transient effect might occur as far as 1 mile away.

$\star_{R}$. A. Just and V. S. Emler, "Generic Report on Health Effects for the U.S.
Gaseous Diffusion Plants," DOE Report K/D 5050, Section VIII, Part 1, 1984. 
It is Commission policy for nuclear power plant accidents to plan to avoid acute fatalities and serious injuries for the worst case accidents. With this in mind, the recommended protective action distance for rupture of a 14-ton cylinder would be 1 mile. The protective actions could be movement out of the plume, sheltering in buildings, or ad hoc respiratory protection, depending on practicality and feasibility in the actual situation. This would avoid acute fatalities and serious injuries for worst-case accidents and transient kidney injury under more typical conditions.

HF: Estimates of the health effects are from a recent DOE report.* The effects described here are based on concentration as applied to a 15 minute exposure:

\begin{tabular}{lc} 
Health effect & HF concentration $\left(\mathrm{mg} / \mathrm{m}^{3}\right)$ \\
\hline & 3500 \\
Lethal (15 min) & 100 \\
Unbearable for 1 min & 13 \\
Irritation (15 min) & \\
Detectable by smell but & 2.5 \\
no health effects &
\end{tabular}

From the calculated HF exposures given above, lethal exposures offsite are not plausible.

Levels for permanent injury are not known. As a consequence we are substituting the concentration of $100 \mathrm{mg} / \mathrm{m}^{3}$ as the level considered to be "unbearable" for more than a minute. Such levels may occur out to about 1500 meters under adverse conditions. Generally, they would not be expected to occur offsites under typical conditions $(D, 4.5 \mathrm{~m} / \mathrm{s})$ if one discounts somewhat the ground level release values.

Irritation appears possible out to at least 5000 meters ( 3 miles) under adverse meteorology and roughly $1500 \mathrm{~m}$ ( $1 \mathrm{mile}$ ) under typical conditions.

Thus the consequences of HF exposure are similar in severity to those from uranium intake. Consequently the one-mile evacuation suggested for the rupture of a 14-ton cylinder of $U_{6}$ is appropriate for protection against both uranium and $U_{6}$.

$*_{R}$. A. Just and V. S. Emler, "Generic Report on Health Effects for the U.S. Gaseous Diffusion Plants," DOE Report K/D 5050, Section VIII, Part 1, 1984. 
The U.S. Department of Transportation has also established evacuation guides for $\mathrm{HF}$ releases.* For small leaks (drum, small container, small leak from a tank) the DOT recommends isolation in all directions to a distance of 150 feet (45 meters). For a large spill from a tank (i.e. railroad tank car) the DOT recommends isolation in all directions to a distance of 300 feet ( 90 meters) and then evacuation in a downwind direction to a distance of $1.5 \mathrm{mile}$ and a width of 0.8 mile. The DOT distances, however, are based on a larger quantity of HF. Thus, the one-mile action distance suggested here is consistent with DOT recommendations. DOT distances are based on atmospheric stability Class $D$ and wind speed of $4.5 \mathrm{~m} / \mathrm{s}$. DOT states that distances based on those assumptions have proven to be adequate under actual accident situations.

\subsubsection{Enrichment P1ants}

At present there are no NRC-licensed enrichment plants, nor are there any immediate prospects for one. Basically, however, enrichment plants receive $\mathrm{UF}_{6}$ from conversion plants and ship $\mathrm{UF}_{6}$, enriched in $\mathrm{U}-235$, to fuel fabrication plants. Thus the types of potential accidents are similar to those at conversion plants and fuel fabrication plants.

\subsubsection{Accident History}

Several large releases of $\mathrm{UF}_{6}$ have occurred at enrichment plants, as shown in Table 4. These have been the result of the ruptures of heated large 10-ton or 14-ton cylinders. The largest release was the 1978 cylinder rupture at the Portsmouth, Ohio gaseous diffusion plant, which released $9500 \mathrm{~kg}$ of $\mathrm{UF}_{6}$.

*"Hazardous Materials-Emergency Response Guidebook," U.S. Department of Transportation report DOT-P5800.4, 1987. 


\subsubsection{Accident Source Terms}

Source terms for two types of accidents are considered: $\mathrm{UF}_{6}$ releases and criticality accidents.

The $U F_{6}$ release for natural uranium is considered to be the same as for the $U F_{6}$ release previously discussed for $U_{F_{6}}$ conversion plants in Section 2.2.3.2. $T^{T} U_{6}$ releases for enriched uranium are considered to be the same as those for fuel fabrication plants that will be discussed in Section 2.2.5.2.

The criticality accidents is assumed to be the same at the criticality accident for the fabrication plants that will be discussed in Section 2.2.5.2.

\subsubsection{Calculations of Doses}

Doses due to a $U_{6}$ release from the rupture of a 14-ton cylinder of natural uranium are the same as those given in Section 2.2.3.3 for $U F_{6}$ conversion plants. Doses due to $\mathrm{UF}_{6}$ releases of low and high enriched uranium are the same as those that will be given in Section 2.2.5.3 for fuel fabrication plants.

Doses due to a criticality are the same as those given for a criticality at a fuel fabrication plant in Section 2.2.5.3.

\subsubsection{Implications for Emergency Preparedness}

Offsite emergency preparedness at uranium enrichment plants should be based on chemical toxicity from a large $U_{6}$ release. Thus, uranium enrichment plants should be considered a potential chemical haz, rd, not a radiation hazard.

Basically, uranium enrichment plants should have the same level of offsite emergency preparedness as $\mathrm{UF}_{6}$ conversion plants. Currently, enrichment plants, if licensed, would be covered under Part 50 of NRC regulations. The emergency preparedness requirements in Part 50, which were developed for nuclear power plants, are clearly excessive for enrichment plants. However, because NRC does not currently license any enrichment plants, the discrepancy is academic. 


\subsubsection{Fuel Fabrication - Uranium}

Fuel fabrication plants generally receive $U_{6}$ enriched in the uranium-235 isotope, convert it generally into highly refractory uranium oxides, form the uranium oxides into pellets, and load the pellets into metal-clad fuel elements for shipment to nuclear power plants. In most cases the uranium-235 is enriched to less than 5\%, but at several plants the enrichment exceeds $93 \%$. However, only one licensed plant (Nuclear Fuel Services, Erwin, Tennessee) currently handles the volatile $U_{6}$ in highly enriched form.

\subsubsection{Accident History}

Among the accidents that have occurred in processing uranium are criticality accidents, fires, and releases of $\mathrm{UF}_{6}$.

Since the first successful self-sustaining nuclear chain-reaction there have been no less than 37 occasions when the power level of fissile systems rose unexpectediy because of unplanned or unexpected changes in system reactivity. Of these 37 cases, six cases caused eight deaths, two of which occurred in the early, rushed pace near the end of World War II.

of these 37 criticalities, eight occurred in fuel cycle facilities ( 7 in the U.S. and one abroad) and are thus relevant to this analysis. The remaining 29 occurred in nuclear reactors or critical assembly experiments. The seven relevant U.S. fuel cycle facility criticalities are listed in Table 5. One occurred in a licensed facility (Wood River Junction, R.I., 1964).

There are several lessons about criticalities that can be learned from studying these accidents. Accidental criticalities can occur and occasionally do. When they occur the doses to workers can be very large, sometimes fatal, and sometimes requiring hospitalization. Radioactive solutions can be ejected and can contaminate workers and the plant area. No offsite contamination or radiation doses have been reported. 
Table 5. Criticality Accidents In Fuel Cycle Facilities through 1986

\begin{tabular}{|c|c|c|c|c|c|c|c|c|}
\hline Date & Location & Process & Cause & $\begin{array}{l}\text { Total } \\
\text { Fissions }\end{array}$ & Duration & Personnel Exposures & $\begin{array}{l}\text { Contamination } \\
\text { In-plant }\end{array}$ & $\begin{array}{l}\text { Contamination } \\
\text { Out of } \\
\text { Building }\end{array}$ \\
\hline $\begin{array}{l}\text { June } 16 \\
1958\end{array}$ & $\begin{array}{l}\text { Y-12 Process- } \\
\text { ing Plant, } \\
\text { Oak Ridge, TN }\end{array}$ & $\begin{array}{l}\text { Recovery of highly } \\
\text { enriched uranium } \\
\text { by chemical } \\
\text { methods. }\end{array}$ & $\begin{array}{l}\text { Wash water added to } \\
\mathrm{UO}_{2}\left(\mathrm{NO}_{3}\right)_{2} \text { solution } \\
\text { in 55-gal. drum. }\end{array}$ & $1.3 \times 10^{18}$ & $18 \min$ & $\begin{array}{l}8 \text { people. Doses of } 461 \text {, } \\
418,413,341,298,87 \text {, } \\
29 \text { rads. No fatalities. }\end{array}$ & $\begin{array}{l}\text { Small local } \\
\text { contamination }\end{array}$ & $\begin{array}{l}\text { None } \\
\text { reported }\end{array}$ \\
\hline $\begin{array}{l}\text { Dec. } 30 \\
1958\end{array}$ & $\begin{array}{l}\text { Pu Process- } \\
\text { ing Plant, } \\
\text { Los Alamos, NM }\end{array}$ & $\begin{array}{l}\text { Recovery of } \\
\text { plutonium from } \\
\text { scrap. }\end{array}$ & $\begin{array}{l}\text { Liquid phases of } \\
\text { plutonium separated } \\
\text { out. }\end{array}$ & $1.5 \times 10^{17}$ & $1 \mathrm{sec}$ & $\begin{array}{l}3 \text { people. Doses of } \\
12,000,134,53 \text { rads. } \\
\text { One fatality. }\end{array}$ & $\begin{array}{l}\text { None } \\
\text { reported }\end{array}$ & $\begin{array}{l}\text { None } \\
\text { reported }\end{array}$ \\
\hline $\begin{array}{l}\text { Oct. } 16 \\
1959\end{array}$ & $\begin{array}{l}\text { Idaho Chemical } \\
\text { Processing } \\
\text { Plant, Idaho } \\
\text { Reactor Test } \\
\text { Site }\end{array}$ & $\begin{array}{l}\text { Transfer of highly } \\
\text { enriched uranium } \\
\text { solution. }\end{array}$ & $\begin{array}{l}\text { Solution transferred } \\
\text { to unsafe geometry } \\
\text { ( } 5000 \text { gal tank) }\end{array}$ & $4 \times 10^{19}$ & $\begin{array}{l}15 \text { to } \\
20 \text { min }\end{array}$ & $\begin{array}{l}19 \text { people. No direct } \\
\text { gamma or neutron dose } \\
\text { because tank was } \\
\text { shielded, but beta } \\
\text { doses from released } \\
\text { radio activity of } \\
50 \text { rem, } 32 \text { rads, and } \\
\text { smaller amounts for } \\
17 \text { other people. }\end{array}$ & $\begin{array}{l}\text { Yes } \\
\text { airborne } \\
\text { beta } \\
\text { activity }\end{array}$ & $\begin{array}{l}\text { Not } \\
\text { reported }\end{array}$ \\
\hline$\underset{1961}{\operatorname{Jan} .25}$ & $\begin{array}{l}\text { Idaho Chemical } \\
\text { Processing } \\
\text { Plant, Idaho } \\
\text { Reactor Test } \\
\text { Site }\end{array}$ & $\begin{array}{l}\text { Transfer of highly } \\
\text { enriched uranium } \\
\text { solution. }\end{array}$ & $\begin{array}{l}\text { Solution transferred } \\
\text { to unsafe geometry }\end{array}$ & $6 \times 10^{17}$ & $1 \mathrm{sec}$ & $\begin{array}{l}\text { None. Shielded } \\
\text { operation }\end{array}$ & $\begin{array}{l}\text { None } \\
\text { reported }\end{array}$ & $\begin{array}{l}\text { None } \\
\text { reported }\end{array}$ \\
\hline $\begin{array}{l}\text { April } 7 \\
1962\end{array}$ & $\begin{array}{l}\text { Hanford Works, } \\
\text { Richland, WA }\end{array}$ & $\begin{array}{l}\text { Plutonium } \\
\text { processing }\end{array}$ & $\begin{array}{l}\text { Plutonium solution } \\
\text { incorrectly siphoned }\end{array}$ & $8 \times 10^{17}$ & $37.5 \mathrm{hr}$ & $\begin{array}{l}3 \text { people. Doses of } 110 \\
43,19 \text { rads. }\end{array}$ & $\begin{array}{l}\text { None } \\
\text { reported }\end{array}$ & $\begin{array}{l}\text { None } \\
\text { reported }\end{array}$ \\
\hline $\begin{array}{l}\text { July } 24 \\
1964\end{array}$ & $\begin{array}{l}\text { Scrap Recovery } \\
\text { Plant, Wood } \\
\text { River Junction, } \\
\text { RI }\end{array}$ & $\begin{array}{l}\text { Recovery of highly } \\
\text { enriched uranium }\end{array}$ & $\begin{array}{l}\text { Solution hand-poured } \\
\text { into unsafe geometry }\end{array}$ & $1.3 \times 10^{17}$ & $\begin{array}{l}2 \text { short } \\
\text { pulses } \\
1.5 \text { hrs } \\
\text { apart }\end{array}$ & $\begin{array}{l}3 \text { people. Doses of } \\
10,000,100,60 \text { rads. } \\
\text { One fatality. }\end{array}$ & $\begin{array}{l}20 \% \text { of } \\
\text { solution } \\
\text { splashed } \\
\text { out of tank }\end{array}$ & $\begin{array}{l}\text { None } \\
\text { reported }\end{array}$ \\
\hline $\begin{array}{l}\text { Oct. } 17 \\
1978\end{array}$ & $\begin{array}{l}\text { Chemical } \\
\text { Processing } \\
\text { Plant, NRTS, ID }\end{array}$ & $\begin{array}{l}\text { Solvent extraction } \\
\text { column }\end{array}$ & & $3 \times 10^{18}$ & 15 min & $\begin{array}{l}\text { Less than . } 13 \text { rem. } \\
\text { (In shielded cell) }\end{array}$ & $\begin{array}{l}\text { Air monitors } \\
\text { detected } \\
\text { considerable } \\
\text { activity } \\
\mathrm{T}_{2}<1 \mathrm{hr}\end{array}$ & $\begin{array}{l}\text { Filters } \\
\text { removed } \\
\text { most } \\
\text { particles }\end{array}$ \\
\hline Referenc & $\begin{array}{l}\text { William R. St } \\
\text { October } 17,1\end{array}$ & $\begin{array}{l}\text { itton, "A Review } \\
\text { 8," DOE Report AC }\end{array}$ & Criticality $A C$ & AEC R & & 196 & $p$ from Critica & ity Event of \\
\hline
\end{tabular}


A number of fires and explosions involving uranium or thorium, which would behave similarly, have been reported. Uranium metal is pyrophoric. Uranium metal, heated or in powdered form or heated as a solid will spontaneously ignite if exposed to air. Reported fires and explosions involving uranium or thorium are included in'Table 6 below. What is noteworthy is that these fires have had little consequence with regard to either personnel exposure or ground contamination. Reported offsite contamination levels were generally below the levels that the NRC allows on equipment to be released for unrestricted use.*

By comparison, the accident record for plutonium, which has a much higher specific activity, is much different. Plutonium accidents have been characterized by extensive radioactive contamination and personnel exposures. Yet even the most serious of these accidents, the Rocky Flats fire, caused only a small fraction of the plutonium involved to be released. Of hundreds of kilograms of plutonium involved in the fire, only $0.003 \mathrm{~g}$ was released through a damaged exhaust system. ** Thus the overall release fraction for plutonium was about $10^{-8}$, based on the estimated release quantity compared to the quantity involved in the fire.**

Table 7 lists other accidents involving uranium fuel fabrication, but not including $U_{6}$ releases, fires, or exposions which were listed previously. These accidents in Table 7 all involved ventilation systems. None of the accidents listed in Table 7 caused any offsite doses approaching the 1 rem lower limit of the protective action guides.

\footnotetext{
* Surface contamination levels for uranium allowable on equipment to be released for unrestricted use are average: $5000 \mathrm{dpm}$ alpha/100 $\mathrm{cm}^{2}$, maximum: 15,000 dpm alpha/100 $\mathrm{cm}^{2}$, and removable: $1000 \mathrm{dpm}$ alpha/100 $\mathrm{cm}^{2}$. These values are found in Regulatory Guide 1.86, "Termination of Operating Licenses for Nuclear Reactors," and "Guidelines for Decontamination of Facilities and Equipment Prior to Release for Unrestricted Use or Termination of Licenses for Byproduct, Source, or Special Nuclear Material," USNRC, July, 1982.

${ }^{*}$ H. K. Elder, "Technology, Safety and Costs of Decommissioning Reference Nuclear Fuel Cycle and Non-fuel Cycle Facilities Following Postulated Accidents," NUREG/CR-3293, Vo1. 1, page 3.3, 1985.
} 
Table 6. Fires and Explosions Involving Uranium and Thorium through 1986

\begin{tabular}{|c|c|c|c|}
\hline Date & Facility & Release & Description \\
\hline $6-27-49$ & $\begin{array}{l}\text { Los Alamos } \\
\text { Laboratory, NM }\end{array}$ & None reported & $\begin{array}{l}\text { Fire broke out in a drum } \\
\text { containing uranium metal } \\
\text { turnings. }\end{array}$ \\
\hline $10-29-52$ & $\begin{array}{l}\text { Truck in Kansas } \\
\text { City, MO }\end{array}$ & Considerable & $\begin{array}{l}\text { Truck carrying uranium } \\
\text { metal burned. Uranium } \\
\text { ignited and much was lost. }\end{array}$ \\
\hline $12-9-52$ & AEC facility & None & $\begin{array}{l}\text { Molten uranium metal was } \\
\text { being cast in a vacuum. } \\
\text { Spill ruptured vacuum. } \\
\text { Uranium then burned. }\end{array}$ \\
\hline $6-12-53$ & U.S. & $\begin{array}{l}\text { Onsite contamina- } \\
\text { tion up to } 15,000 \\
\mathrm{dpm} / 100 \mathrm{~cm}^{2} .\end{array}$ & $\begin{array}{l}\text { Explosion of powdered } \\
\text { uranium and } \mathrm{CCl}_{4} \text { in } \\
\text { glovebox. }\end{array}$ \\
\hline $8-20-56$ & AEC contractor & $\begin{array}{l}100,000 \mathrm{dpm} / \\
100 \mathrm{~cm}^{2} \text { onsite. } \\
500 \mathrm{dpm} / 100 \mathrm{~cm}^{2} \\
\text { offsite. }\end{array}$ & Thorium explosion \\
\hline $9-21-56$ & $\begin{array}{l}\text { Truck in Detroit, } \\
\text { MI }\end{array}$ & None & $\begin{array}{l}\text { Drum containing thorium } \\
\text { metal started to burn. } \\
\text { No contamination. No } \\
\text { exposures. }\end{array}$ \\
\hline $6-23-58$ & $\begin{array}{l}\text { AEC contractor } \\
\text { Attleboro, MA }\end{array}$ & $\begin{array}{l}\text { No material } \\
\text { loss }\end{array}$ & $\begin{array}{l}\text { Fire in slightly } \\
\text { enriched uranium scrap } \\
\text { in perchloroethylene. }\end{array}$ \\
\hline $9-26-60$ & $\begin{array}{l}\text { M\&C Nuclear } \\
\text { Attleboro, MA }\end{array}$ & $\begin{array}{l}\text { Enriched U } \\
\text { no exposures. }\end{array}$ & $\begin{array}{l}\text { Magnesium explosion in } \\
\text { vacuum induction furnace. }\end{array}$ \\
\hline $9-20-63$ & $\begin{array}{l}\text { Controls, Inc. } \\
\text { Attleboro, MA }\end{array}$ & $\begin{array}{l}\text { None } \\
\text { detected }\end{array}$ & $\begin{array}{l}\text { Fire in filter box } \\
\text { exhausting enriched } \\
\text { uranium. No contamination } \\
\text { on or offsite. }\end{array}$ \\
\hline $6-29-67$ & $\begin{array}{l}\text { Kerr-McGee } \\
\text { Crescent, OK }\end{array}$ & Minor & $\begin{array}{l}\text { Explosion in ion exchange } \\
\text { column. }\end{array}$ \\
\hline $9-2-72$ & $\begin{array}{l}\text { United Nuclear } \\
\text { Fuel fabrication } \\
\text { facility }\end{array}$ & $\begin{array}{l}\text { Uranium at } \\
15 \text { times MPC }\end{array}$ & $\begin{array}{l}\text { Flash fire caused by } \\
\text { organic contaminants in } \\
\text { ductworks. Considerable } \\
\text { damage. }\end{array}$ \\
\hline $3-12-81$ & $\begin{array}{l}\text { Nuclear Metals } \\
\text { Concord, MA }\end{array}$ & $\begin{array}{l}\text { Minor inplant } \\
\text { contamination }\end{array}$ & $\begin{array}{l}\text { Fire in scrap packaging } \\
\text { building from spontaneous } \\
\text { combustion of } 10 \text { lbs of } \\
\text { uranium turnings. No } \\
\text { overexposures. }\end{array}$ \\
\hline
\end{tabular}


Table 7. Other Accidental Releases from Uranium Fuel Fabrication Plants through $1986\left(\mathrm{UF}_{6}\right.$ releases, fires, and explosions excluded)

\begin{tabular}{|c|c|c|c|}
\hline Date & Facility & Release & Accident description \\
\hline $4-2-71$ & $\begin{array}{l}\text { Babcock and Wilcox } \\
\text { Research Facility } \\
\text { Lynchburg, VA }\end{array}$ & $\begin{array}{l}10 \text { Microcurie in } \\
\text { plant }\end{array}$ & $\begin{array}{l}\text { Contamination outside a } \\
\text { hot cell due to a plug } \\
\text { being installed without } \\
\text { a sealing bellows. }\end{array}$ \\
\hline $2-28-73$ & $\begin{array}{l}\text { General Electric, } \\
\text { Wilmington, NC }\end{array}$ & Below MPC & HEPA filter failed. \\
\hline $8-24-73$ & $\begin{array}{l}\text { Babcock and Wilcox } \\
\text { Apo } 110, \text { PA }\end{array}$ & $\begin{array}{l}\text { Decontamination } \\
\text { required on and } \\
\text { offsite. Release } \\
\text { was } 6.3 \text { microcuries. }\end{array}$ & $\begin{array}{l}\text { Enriched uranium released } \\
\text { when corroded scrubber } \\
\text { spray nozzle did not } \\
\text { provide enough scrubbing. }\end{array}$ \\
\hline $12-8-73$ & $\begin{array}{l}\text { Babcock and Wilcox } \\
\text { Apollo, PA }\end{array}$ & $\begin{array}{l}\text { Offsite release of } \\
\text { natural uranium } \\
4 \text { times MPC. Offsite } \\
\text { decontamination } \\
\text { required. }\end{array}$ & $\begin{array}{l}\text { Inadequate ventilation } \\
\text { of calciner allowed } \\
\text { uranium to escape } \\
\text { through canopy exhaust. }\end{array}$ \\
\hline $9-6-74$ & $\begin{array}{l}\text { Westinghouse } \\
\text { Columbia, SC }\end{array}$ & $\mathrm{UO}_{2}$ & $\begin{array}{l}\text { Leak in a roughing filter } \\
\text { allowed } \mathrm{UO}_{2} \text { power to be } \\
\text { discharged directly to } \\
\text { the air. }\end{array}$ \\
\hline $1-24-75$ & $\begin{array}{l}\text { Babcock and Wilcox } \\
\text { Apol10, PA }\end{array}$ & Enriched uranium & $\begin{array}{l}\text { Malfunction of scrubber/ } \\
\text { ventilation system. }\end{array}$ \\
\hline $1-79$ & $\begin{array}{l}\text { General Electric, } \\
\text { Wilmington, NC }\end{array}$ & $\begin{array}{l}62 \mathrm{Kg} \text { of } 1 \mathrm{ow} \\
\text { enriched } \mathrm{UO}_{2} \text { powder } \\
\text { stolen. }\end{array}$ & $\begin{array}{l}\text { Two cans of powder stolen } \\
\text { and used in extortion } \\
\text { attempt. Thief arrested, } \\
\text { convicted and imprisoned. } \\
\text { Powder recovered. }\end{array}$ \\
\hline
\end{tabular}




\subsubsection{Theoretical Calculations of Releases}

Criticality accidents, $\mathrm{UF}_{6}$ releases, fires, explosions, and tornadoes have been considered in various analyses of accidents in a fuel fabrication plant. The most serious accidents appear to be criticalities and $\mathrm{UF}_{6}$ releases. Thus, we consider those accidents here.

Criticality Accident: the NRC staff has developed a set of assumptions on the release of radioactive fission products from a criticality accident occurring in a solution. The assumptions are published in Regulatory Guide 3.34, "Assumptions Used for Evaluating the Potential Radiological Consequences of Accidental Nuclear Criticality in a Uranium Fuel Fabrication Plant," July 1979.

Regulatory Guide 3.34 assumes a criticality excursion occurs in a vented vessel of unfavorable geometry containing a solution of $400 \mathrm{~g} / 1$ of uranium enriched in U-235. The excursion produces an initial burst of $10^{18}$ fissions in 0.5 second followed successively at 10 minute intervals by 47 bursts of $1.9 \times 10^{17}$ fissions each for a total of $10^{19}$ fissions in 8 hours. The excursion is assumed to be terminated by evaporation of 100 liters of the solution. The amounts of radioactive materials assumed to be released from the solution vessel to the room air are given in Table 8.

Regulatory Guide 3.34 allows credit for removal of fission products by filters in the ventilation system. In order to escape to the environment the room air must pass through a filter system by means of the building ventilation system. Even if doors are opened the ventilation system should exhaust the fission products through the filters. In this analysis the filters are assumed to remove $75 \%$ of the iodine but none of the inert gases. This analysis assumed the ventilation system operates at 5 air changes per hour.

The NRC staff has recently analyzed the potential consequences assuming a criticality accident for Exxon Nuclear in Richland, Washington,* Combustion Engineering in Hematite, Missouri, ${ }^{\star *}$ and Nuclear Fuel Services in Erwin,

\footnotetext{
*"Environmental Impact Appraisal, Exxon Nuclear Company, Nuclear Fuel Fabrication Plant, Richland, Washington," Docket 70-1257, NRC Office of Nuclear Material Safety and Safeguards, August, 1981.

**"Environmental Assessment, Combustion Engineering, Inc., Nuclear Fuel Fabrication Plant, Hematite, Missouri," Docket 70-36, NRC Office of Nuclear Material Safety and Safeguards, November, 1982.
} 
Table 8. Amounts of Radioactive Materials Released to Room Air Due to a Criticality Accident ( $10^{18}$ fissions initially and $1.9 \times 10^{17}$

fissions every 10 minutes for 8 hours)

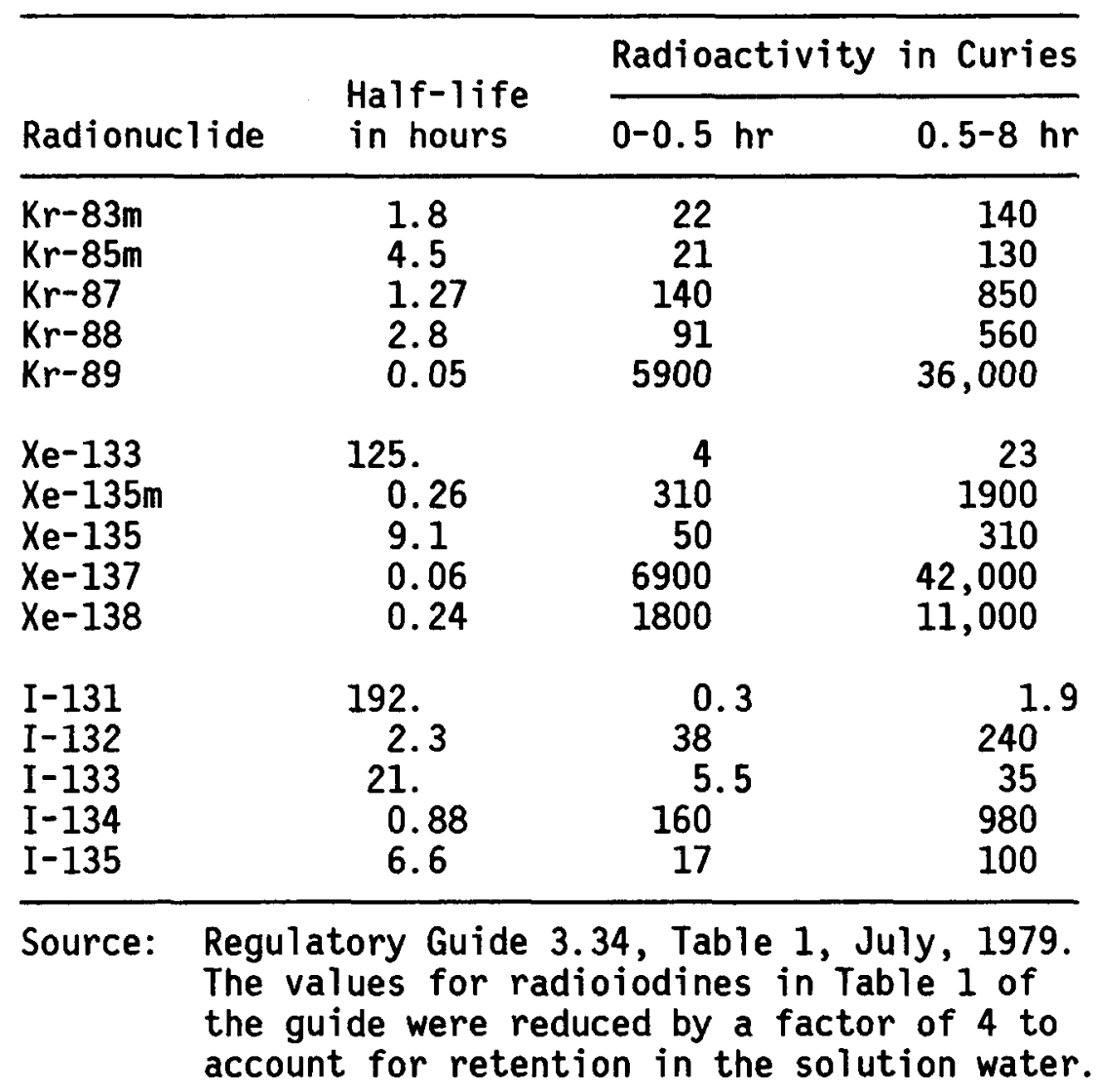

Tennessee.* In each case the radionuclide releases from Regulatory Guide 3.34 were used.

Low-enriched $\mathrm{UF}_{6}$ : The Exxon and Combustion Engineering analyses** also considered releases of $U_{6}$, as did a recent analysis for the General Electric fuel fabrication plant in Wilmington, North Carolina. $\dagger$ The worst-case accident in the Exxon and Combustion Engineering analyses was assumed to involve the release of $U_{6}$ as might occur from valve or line failure of a heated cylinder being unloaded. Assuming that a full cylinder of $U_{6}(2500 \mathrm{~kg})$ at elevated

\footnotetext{
*"Proposed New Emergency Preparedness License Conditions at NFS-Erwin," NRC Commission Paper SECY-82-311, July 23, 1982.

**op. cit.

†"Environmental Impact Appraisal, General Electric Company, Wilmington Manufacturing Department," Office of Nuclear Material Safety and Safeguards," NUREG-1078, June, 1984, page 69.
} 
temperature started to leak and that no additional heat was supplied after cylinder failure, the NRC staff estimated that about 22 percent of the material would be released before the UF 6 would be cool enough to solidify and have a vapor pressure low enough so that the release would stop. The NRC staff estimated that such a release would last for 15 minutes, and $540 \mathrm{~kg}$ of UF 6 would be released. This has a uranium content of $360 \mathrm{~kg}$. The staff assumed the uranium released would react with water in the air and form highly soluble $\mathrm{UO}_{2} \mathrm{~F}_{2}$ of a respirable particle size.

High-enriched $U_{6}$ : In evaluating the need for offsite emergency preparedness at Nuclear Fuel Services, Erwin, Tennessee, the NRC staff concluded that the $U_{6}$ accident to be considered was release from a $15-\mathrm{kg}$ cylinder containing high enriched uranium. * This is largest cylinder used at the site for highly enriched $U_{6}$. An accident in 1962 breached one cylinder. Of the 15-kg contents, $6 \mathrm{~kg}$ was recovered but $9 \mathrm{~kg}$ was not recovered and presumably much of the material escaped from the plant.

\subsubsection{Calculations of Doses}

Potential radiation doses due to criticality accidents and $U F_{6}$ releases previously calculated by the NRC staff for Combustion Engineering, Exxon, and Nuclear Fuel Services are summarized in Table 9.

Criticality accident: To calculate the dose due to a criticality accident, the Exxon analysis assumed a wind speed of $1 \mathrm{~m} / \mathrm{sec}$, atmospheric stability class $F$, and a building wake factor of 1.0 beyond 500 meters (i.e. no building wake assumed). The building ventilation rate is assumed to be 30 air changes/hr. The whole body doses were calculated to be 0.004 rem at $3600 \mathrm{~m}$ (the nearest residence) and $0.009 \mathrm{rem}$ at $2000 \mathrm{~m}$ (the nearest industrial site). The doses to the thyroid were calculated to be $1.7 \mathrm{rem}$ at $3600 \mathrm{~m}$ and $4.5 \mathrm{rem}$ at $2000 \mathrm{~m}$. If one assumed only $25 \%$ of the iodines would pass through the filter system, the thyroid doses would be $0.4 \mathrm{rem}$ at $3600 \mathrm{~m}$ and $1.1 \mathrm{rem}$ at $2000 \mathrm{~m}$.

The NRC analysis for the Combustion Engineering plant made similar assumptions. The whole body dose at the nearest residence $(800 \mathrm{~m})$ would be 0.27 rem. The thyroid dose at $800 \mathrm{~m}$ would be $1.7 \mathrm{rem}$. If the filters reduced the iodine concentrations by $75 \%$, the thyroid dose would be $0.4 \mathrm{rem}$.

*"Proposed New Emergency Preparedness License Conditions at NFS-Erwin," NRC Commission Paper SECY-82-311, July 23, 1982. 
Table 9. Offsite Doses Calculated for Fuel Fabrication Plants

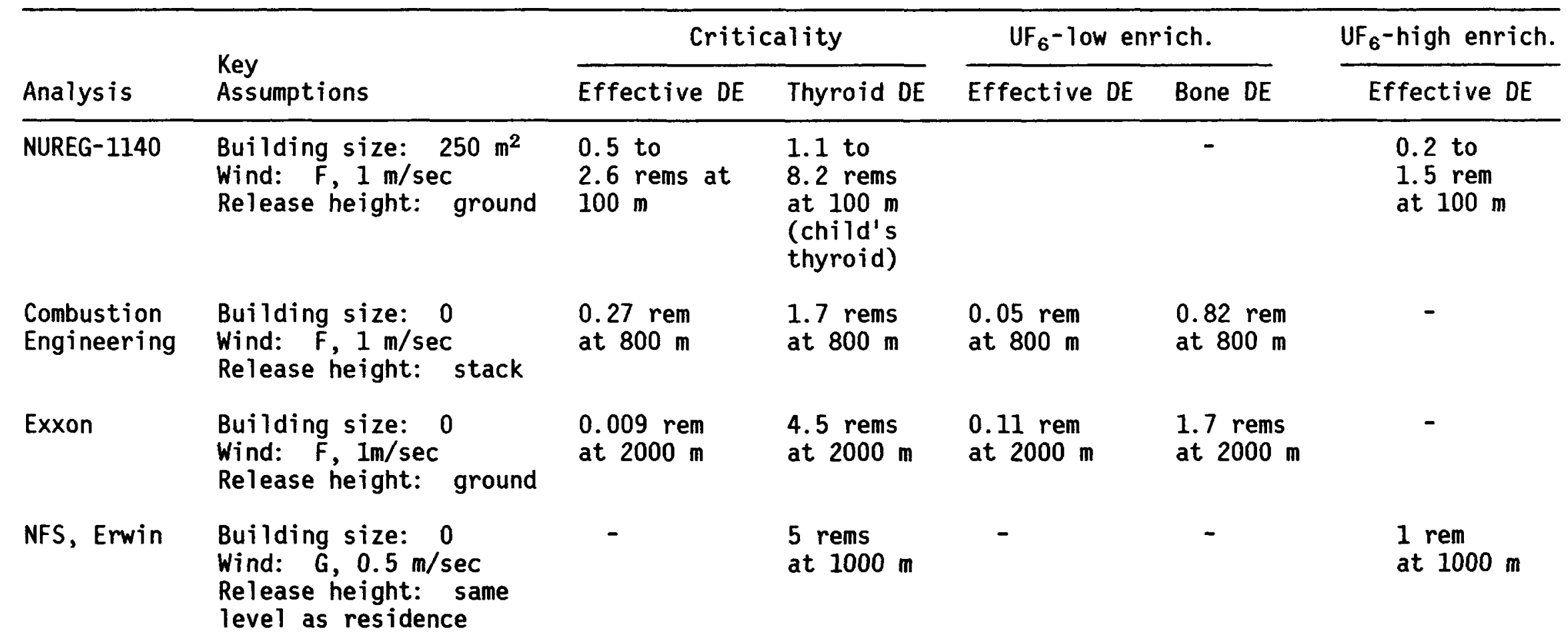


This analysis calculated an effective dose equivalent due to the airborne release from a criticality as 0.5 to 2.6 rem at $100 \mathrm{~m}$. The dose from prompt gammas and neutrons from excursions after the first one should be added to that dose, but those doses have not yet been calculated.

We calculated the thyroid dose to a child due to the radioiodine release from a criticality accident to be 1.1 to 8.2 rems at $100 \mathrm{~m}$.

Low-enriched $\mathrm{UF}_{6}$ : For the $\mathrm{UF}_{6}$ release, the Exxon plant analys is assumed a ground level release and calculated a dose to the bone of 1.7 rem at $2000 \mathrm{~m}$. The whole body dose was calculated to be 0.11 rem. In the analysis the NRC staff published for the Combustion Engineering plant, the release was assumed to be through a stack. The bone dose was calculated to be 0.82 rem at $800 \mathrm{~m}$. The whole body dose was calculated to be 0.05 rem.

For purposes of this Regulatory Analysis uranium intakes and HF concentrations have been calculated. Radiation doses were not calculated since they are of lesser concern.

The release was assumed to be $540 \mathrm{~kg}$ of $U_{6}$ at ground level. The uranium content is $364 \mathrm{~kg}$. Atmospheric dispersion values from figure 1 were used. Uranium intakes are shown below for ground level releases. Buoyant releases are not calculated because there may not be enough material to create buoyancy.

$\begin{aligned} & \text { Uranium intakes due to a ground } \\
& \text { level release of } 540 \mathrm{~kg} \text { of } \mathrm{UF}_{6}\end{aligned}$
\begin{tabular}{lcc} 
& & \\
Distance & Uranium intake (mg) \\
\cline { 2 - 3 } (meters) & F, $1 \mathrm{~m} / \mathrm{s}$ & D, $4.5 \mathrm{~m} / \mathrm{s}$ \\
\hline 100 & 320 & 43 \\
200 & 150 & 16 \\
300 & 90 & 9 \\
400 & 42 & 3 \\
500 & 24 & 2.2 \\
1000 & 14 & 1.4 \\
1500 & 6 & 0.8 \\
2000 & 4 & 0.5 \\
5000 & 0.5 & 0.1
\end{tabular}

High-enriched $U_{6}$ : For the Nuclear Fuel Services Plant, the NRC staff previously calculated the effective dose equivalent at $1000 \mathrm{~m}$ due to the release of $15 \mathrm{~kg}$ of $U_{6}$, high-enriched, to be 1 rem. For a $9 \mathrm{~kg}$ release of high enriched uranium, we calculated an effective dose equivalent of 0.2 to 
1.5 rems at $100 \mathrm{~m}$, a uranium intake of 0.3 to $2.6 \mathrm{mg}$, and exposure to $\mathrm{HF}$ at a concentration of 1.0 to $7.8 \mathrm{mg} / \mathrm{m}^{3}$. A building size of $10 \mathrm{~m} \times 25 \mathrm{~m}$, neutral buoyancy for the plume, ground level release, 5-minute release duration, $1.5 \%$ $\mathrm{U}-234$ with solubility Class $D$ for uranium and $F, 1 \mathrm{~m} / \mathrm{s}$ and $D, 4.5 \mathrm{~m} / \mathrm{s}$ meteorology were the assumptions.

\subsubsection{Implications for Emergency Preparedness}

The implications of criticality accidents and $U_{6}$ releases are discussed separately below.

Criticality accident: Using what are believed to be reasonable assumptions, at $100 \mathrm{~m}$ effective dose equivalents of 0.5 to $2.6 \mathrm{rems}$ for $\mathrm{F}, 1 \mathrm{~m} / \mathrm{s}$ and D, $4.5 \mathrm{~m} / \mathrm{s}$ meteorologies were calculated compared to a 1 to 5 rem protective action guide. A child's thyroid dose of 1.1 to 8.2 rems was calculated compared to a 5 to 25 rem protective action guide. The calculated doses exceed the lower end of the range where protective actions should be considered out to about 200 to $250 \mathrm{~m}$.

Low-enriched $U_{6}$ release: For the release of $540 \mathrm{~kg}$ of low-enriched $U_{6}$, lethal intakes $(242 \mathrm{mg}$ ) offsite do not seem plausible. Intakes sufficient to cause permanent kidney injury $(45 \mathrm{mg}$ ) are calculated for adverse meteorology with no buoyancy to about 500 meters, although consideration of buoyancy might easily eliminate calculated permanent injury under any conditions. Transient kidney effects might occur to 1000 meters under worse case meteorology and to perhaps about 300 meters under more typical meteorology. There would be no observable effects at 400 meters for typical meteorology. Therefore, in keeping with the Commission's policy on nuclear power plant emergency preparedness, avoiding fatalities and serious health effects for worst case and protective action guide doses for more probable events, a response distance of roughly 400 meters is recommended.

High-enriched $U_{6}$ : For the release of $9 \mathrm{~kg}$ of high-enriched $U F_{6}$ during $\mathrm{F}, 1 \mathrm{~m} / \mathrm{s}$ meteorology, the dose at $100 \mathrm{~m}$ is 1.5 rems effective dose equivalent and the uranium intake is $5 \mathrm{mg}$. For $D, 4.5 \mathrm{~m} / \mathrm{s}$ meteorology the dose at $100 \mathrm{~m}$ is 0.2 rem and the uranium intake is $0.7 \mathrm{mg}$. Buoyancy is not considered in either case since the quantity of material is so small. Protection actions to reduce dose may be appropriate during $F, 1 \mathrm{~m} / \mathrm{s}$ meteorology to a distance of $150 \mathrm{~m}$. 


\subsubsection{Fuel Fabrication - Plutonium}

There is currently no plutonium fuel fabrication being done in the U.S., but accidents for facilities fabricating plutonium fuel have been analyzed in NUREG-0002, "Final Generic Environmental Statement on the Use of Recycle Plutonium in Mixed Oxide Fuel in Light Water Cooled Reactors," 1976, usually called "GESMO." Because of the quality and thoroughness of that report, we will directly quote relevant sections for this analysis.

\subsubsection{Accident History*}

"A summary of operational accidents in U.S. Government facilities, from 1943 to 1970 , is given in WASH-1192. For some facilities and operations having a general resemblance to the various mixed oxide fuel cycle steps (in the areas of fuel reprocessing, fuel fabrication, and scrap recovery) there have been a number of accidents. Those which involved the possibility of environmental release include the following:

- Five solution criticality events (1958--2 events; one each in 1959, 1961, and 1962) in reprocessing or recovery operations involving highly enriched uranium or plutonium. All were of small consequence in terms of property damage or releases of radioactivity to the environment, but one fatality and several high radiation exposures occurred among operating personnel.

- Chemical explosion in evaporator (1953), related to fuel reprocessing.

- Explosion and fire in plutonium purification facility (1963).

- Metallic fuel fire (reactive metal) in process dissolver (1960), related to fuel reprocessing.

- Spontaneous fire in radioactively contaminated, combustible waste (1951).

*From GESMO, pages II-45 to II-48. The references given in GESMO are not included here to save space. The reader wanting the references should refer to the original GESMO. 
- Two fires at the Rocky flats plutonium fabrication and recovery facility, (1957) and (1969). The 1969 fire caused $\$ 45$ million in property damage. Both fires are attributable to spontaneous ignition of plutonium metal which is not involved in the mixed oxide fuel cycle.

- Fire around an anion exchange column, fuel reprocessing plant (1964).

"Some of these accidents occurred during the early years of operations with new facilities and newly developed technologies. All were investigated and corrective actions were taken (e.g., design changes) to make the events unlikely of recurrence. Such corrective actions have been carried forward, where applicable, into design practices for new facilities, both government and commercial. During the past decade, criticality accidents have disappeared from the accident scene, and fire or explosion involving reactive metals has become the predominant major accident in government facilities.

"On a comparable basis, accident experience in commercial facilities to date include:

- A solution criticality accident in recovery operations involving highly enriched uranium, fatal to operator (1964).

- A series of dissolver "fires" (reactive metal), fuel reprocessing plant (1967-1968).

- Final HEPA filter bank failure (inadequate mechanical support), fuel reprocessing plant (1968).

- Fire in plutonium contaminated wastes, fuel fabrication facility (1973). There was no detectable release of plutonium to the environment.

- Explosion in plutonium glovebox, fuel fabrication facility (1972). About $5.6 \mu \mathrm{Ci}$ of alpha activity was released via the stack. 
"The measured and estimated quantities of long-lived alpha activity released from the Rocky Flats plant during its first 20 years of operation are summarized in Table II-12....

"The specific and extensive modifications made to all plutonium handling facilities at Rocky Flats subsequent to the 1957 fire (especially the substitution of flame resistant filters for those formerly used, and the addition of fire protection in the filter banks and plenums) were clearly responsible for the vastly improved containment of alpha activity during the 1969 fire. The new plutonium recovery facility now under construction at Rocky Flats (as a replacement for older facilities) is being built under criteria that should provide even greater assurance that the facility will be able to confine plutonium releases to exceedingly small values, even under severe abnormal circumstances--including natural events, such as tornados."

"Table II-12

LONG-LIVED ALPHA ACTIVITY RELEASED FROM ROCKY FLATS

\begin{tabular}{rll}
\hline Date & \multicolumn{1}{c}{ Circumstances } & \multicolumn{1}{c}{ Quantity } \\
\hline $1958-1968$ & $\begin{array}{l}\text { Leakage of Pu contaminated machine oil } \\
\text { stored at the Rocky Flats site }\end{array}$ & $\begin{array}{l}5.3 \mathrm{Ci} \text { to soil at } \\
\text { drum storage area }\end{array}$ \\
1957 & $\begin{array}{l}\text { Fire in Bldg. } 771 \text { resulting in major } \\
\text { damage to filter system }\end{array}$ & $\begin{array}{l}60 \mu \mathrm{Ci} \text {, airborne, } \\
\text { mostly during fire }\end{array}$ \\
1969 & Fire in B1dg. 776 & $\begin{array}{l}0.2 \mu \mathrm{Ci} \text {, airborne, } \\
\text { over } 6 \text {-day period } \\
\text { during and after } \\
\text { fire }\end{array}$ \\
& & $\begin{array}{l}41 \mu \mathrm{Ci} \text {, airborne } \\
91 \mu C i \text { iquid } \\
\text { effluents }\end{array}$ \\
\hline
\end{tabular}




\subsubsection{Accident Source Term*}

"A wide spectrum of credible accidents for these plants has been analyzed and their potential consequences estimated.

"Some incidents, such as punctures or tears of gloves or other glovebox malfunctions, are expected to occur as part of the normal operation. 0ther more serious accidents--such as glovebox window breakage--will occur far less often, although the offsite consequences from such accidents are judged to be insignificant, they are included in the estimate of airborne effluents resulting from normal operations. Upper limit accidents that may occur include a criticality incident, an explosion, or a fire...

Criticality

"There have been no criticality accidents to date in process operations where undermoderation is a primary method of control, and few in aqueous or moderated systems. The number of fissions has been estimated to be $10^{18}$ in an accidental criticality. In calculating the effects, it is assumed that all of the noble gases krypton and xenon and $25 \%$ of the iodine formed by the fissions would escape. In addition, it is assumed that 500 grams of $\mathrm{Pu}$ would become airborne in a glovebox by the accidental criticality excursion. The ventilation filters are assumed to remain intact because a criticality is not an explosive process. The decontamination factor of three HEPA filters in series has been assumed to be $2 \times 10^{7}$, lower by a factor of 50 than the decontamination factor assumed for normal operating conditions. [Pu release $=0.29 \mu \mathrm{Ci}$ alpha] Calculations show that the maximum offsite individual dose commitment results from absorption of fission product iodine in the thyroid and amounts to $360 \mathrm{mrem}$. This is comparable to the dose to the closest theoretical resident from a criticality accident at a $\mathrm{UO}_{2}$ fabrication plant. The slightly different fission product yield and the presence of small amounts of plutonium particulate do not significantly alter the effects of a $\mathrm{PuO}_{2}$ criticality accident relative to those of a $\mathrm{UO}_{2}$ criticality accident.

₹From GESM0, pages IV D-37 to IV D-39. 
Fire

"Unlike a criticality excursion or an explosion, a fire usually is not an instantaneous event and very often starts from a small flame source. The design, construction, and operation of fuel fabrication plants considers in detail the possibility of a fire and equipment and procedures for fire prevention. Regulatory Guide 3.16 presents methods acceptable to the NRC for a fire protection program that should prevent, detect, extinguish, limit, or control fires and explosions and their hazards and damaging effects. Licensees must operate within these or acceptable equivalent constraints. Under these conditions, the probability of a fire of the magnitude considered in this statement is considered highly unlikely. In general, operators have time to react to and extinguish small fires. The process materials, oxides of uranium and plutonium, are not themselves flammable. The final filters are protected against fire by water spray systems installed in the duct some distance upstream of the final filters. Mist deflectors or collectors are installed between the water spray system and the filters to remove large drops of water. The water from the sprays collects in the bottom of the ducts and flows to a fire-water collection tank. This tank is either a safe-geometry tank or a fixed-poison-controlled tank to preclude the possibility of a criticality accident as a result of a fire.

"The final HEPA filters are located some distance from the gloveboxes. This separation distance and the water spray system should be sufficient to protect the filters against the effects of an explosion or fire, but the fire or explosion is assumed to destroy the local filters on the gloveboxes. Plutonium and uranium oxides reach the final filters. Based on an assumed room volume of $1,000 \mathrm{~m}^{3}$ and an air loading of $100 \mathrm{mg} / \mathrm{m}^{3}$ for plutonium oxide particulate, 100 grams of plutonium would reach the filters. Each of the filters is expected to remove $99.9 \%$ of the particulate reaching it, so that a total of $0.1 \mathrm{mg}$ of $\mathrm{Pu}$ passes through the filters. [53 $\mathrm{MCi}$ alpha]

\section{Explosion}

"An explosion might occur in a mixed oxide fuel fabrication plant at locations where an explosive mixture of vapors in air could be present. There is a potential for the existence of combustible gases at the sintering furnance and in the clean scrap reduction operation. In addition, flammable solvents are 
used in the dirty scrap recycle operation and may be used for cleaning fuel rods and during cleanup and maintenance operations. These operations are essentially the only ones that have a potential for supporting an explosion.....

"The consequences of an explosion are similar to those of a fire. The amount of plutonium reaching or passing through the filters is estimated to be the same as that estimated for the fire [53 $\mathrm{CC} i$ alpha] and would have the same relatively minor offsite consequences." [End of quote]

\subsubsection{Calculations of Doses}

For the accidental releases above, GESMO assumed the nearest resident was at $500 \mathrm{~m}$. GESMO used a chi/Q of $1.3 \times 10^{-4}$ for Pasquill Stability Category $D$, wind speed $3 \mathrm{~m} / \mathrm{s}$, and 10 meter release height. GESMO assumed the plutonium to be soluble.

The following dose commitments were calculated for GESMO:

\begin{tabular}{ll} 
Type of accident & Dose commitment (rem) \\
\hline Criticality & 0.36 (thyroid) \\
Fire & 0.02 (bone) \\
Explosion & 0.02 (bone)
\end{tabular}

Using the standard assumptions in this Regulatory Analysis, doses would be slightly higher than those in GESMO.

\subsubsection{Implications for Emergency Preparedness}

The GESMO analysis concluded that the design of plutonium fuel fabrication plants is adequate to prevent releases that would cause doses exceeding protective action guides. Thus special emergency preparedness would not be needed offsite.

In addition, GESMO (page II-10) concluded there was little threat from the ingestion pathway.

"A study of indigenous and experimental animals kept for long periods in areas heavily contaminated with plutonium indicates that direct uptake of plutonium was small. Plutonium uptake by plants from soil and growth media has been investigated in the field and in the laboratory under a variety of conditions. The concentration of plutonium in plants on a dry weight basis was never 
more than one thousandth of that in the growth medium, and only about one ten thousandth of that in the soil. The fraction of available plutonium absorbed from the gastrointestinal tract of animals grazing on contaminated vegetation is less than one ten thousandth the total intake of the element and measurements of plutonium transfer from the blood stream to milk suggest a further reduction in plutonium concentration by another factor of at least 10 . Consumption of animal products by man will introduce another reduction factor of at least 10-4 in the plutonium concentration entering the systemic circulation, except in the very young infant where the factor may approach 0.01 . It appears, therefore, that the possibility of transfer of plutonium from soil to man by way of the food chain is negligible."

\subsubsection{Spent Fuel Storage*}

Spent nuclear power plant fuel may be stored in pools of water, in dry storage casks, in drywells, or dry vault storage. Each of these methods is discussed in this section.

\subsubsection{Accident History}

There have been no accidents associated with spent fuel storage that have had any significance for offsite radiation exposure. Radioactive material has escaped to storage pool water when casks containing damaged fuel elements were opened. However, these events have no significance for offsite emergency preparedness.

\footnotetext{
*Source terms in this section were developed with the assistance of Fritz Sturz, Advanced Fuel and Spent Fuel Licensing Branch, Office of Nuclear Materials Safety and Safeguards, NRC.
} 


\subsubsection{Accident Source Term}

Pool storage: Pool storage for spent fuel storage in pools, possible accidents and their effects are discussed in a generic environmental impact statement, NUREG-0575.*

The accidents considered are:

1. The rupturing of fuel pins due to the drop of a fuel assembly

2. A tornado driven utility pole strikes the pool at the worst-possible angle and ruptures a 45 foot row of assemblies

3. Fires and explosions

4. A criticality accident

5. High radioactivity in the pool water

6. Rupture of a waste tank or piping

7. Lowering of the water level in the pool

8. Loss of the ability to cool the pool water

Of these accidents, the generic environmental impact statement for pool storage estimated that the most serious of these accidents is the rupture of a large number of fuel assemblies by a tornado-driven missile. The statement calculated the release of radioactivity to be 19,000 curies of krypton- 85 and 0.00006 curies of iodine-129. (Actually, I-129 is of only academic interest. Due to saturation, the 5-rem thyroid dose used as the protective action guide cannot be reached.)

A more recent NRC report on pool storage evaluated accident consequences for the General Electric fuel storage facility in Morris, Illinois.** The most serious accident was considered to be the drop of a fuel storage basket in the water of the storage pool. The maximum drop would be about $7 \mathrm{~m}$. While experience with similar drops indicates that only minor damage to a fuel

*NUREG-0575, Generic Environmental Impact Statement on Handling and Storage of Spent Light Water Power Reactor Fuel, pp 4-17 to 4-22, Volume 1, August 1979.

**NUREG-0709, "Safety Evaluation Report related to the Renewal of Materials License SNM-1265 for the Receipt, Storage, and Transfer of Spent Fuel Pursuant to 10 CFR Part 72 - Morris Operation - General Electric Company Docket Nos. 70-1308 and 72-1," July, 1981, Chapter 7. 
assembly would result, the calculations assumed that all the fuel rods in four PWR fuel bundles would rupture and that all the plenum gases would be released to the pool water. The release was calculated to be about $6000 \mathrm{Ci}$ of $\mathrm{Kr}-85$ and $0.00008 \mathrm{Ci}$ of I-129.

Several other types of accidents were also analyzed for the GE-Morris facility. A loss of basin water was considered to be not credible, an earthquake was estimated to cause minimal offsite radiological consequences, a tornado-driven missile was estimated to cause the same release as the fuelbasket drop, and a criticality was estimated to cause minimal offsite doses.

Dry cask storage: The accident assumed for this analysis is the removal of the lid of a dry cask in which all the fuel rods have been damaged. The gaseous activity in the gap between the fuel and cladding is assumed to be released. From NUREG-0575* $10 \%$ of the krypton- 85 and $1 \%$ of the iodine-129 activities are assumed to be in the gap. The cask is assumed to hold 24 PWR spent fuel assemblies. The fuel is assumed to be less than $5 \%$ by weight uranium- 235 .

The fuel burnup for this analysis is assumed to be 33,000 megawatt-days per metric ton of uranium. The fuel is assumed to have been removed from the reactor core 5 years earlier. Using these assumptions the activity released from a cask would be 8,000 curies of krypton-85 and 0.004 curies of iodine-129.

Drywell and dry vault storage: While the number of fuel rods may be larger than assumed for dry cask storage above, it is reasonable to assume that a single accident would not damage a larger number of fuel rods than assumed above for dry cask storage. Therefore, the dry cask storage source term is also appropriate for drywell and dry vault storage.

\subsubsection{Calculations of Doses}

Dose estimates previously published by the NRC staff for the pool releases described above are given in Table 10.

*NUREG-0575, op. cit., Volume 1, p. 4-18. 
Doses for the dry cask storage accident described above calculated in this analysis are also shown in Table 10. The effective dose equivalent for $F, 1 \mathrm{~m} / \mathrm{s}$ meteorology would be 0.003 rem and the child's thyroid dose would be 0.04 rem. For $D, 4.5 \mathrm{~m} / \mathrm{s}$ meteorology, the child's thyroid dose would be $0.005 \mathrm{rem}$.

\subsubsection{Implications for Emergency Preparedness}

The doses shown in Table 10 are below the EPA's protective action guides for taking protective action after an accident. Therefore offsite emergency preparedness is not necessary for spent fuel storage either in dry casks or in pools.

\subsubsection{New Fuel Storage}

New fuel will at times be stored prior to being loaded into a nuclear power plant core. Stored new fuel does not require any offsite emergency preparedness because of its minimal hazard. By comparison with spent fuel storage just discussed, no fission products are present. Thus no volatile radioactive materials are present, and no driving force, such as decay heat, is present to cause the uranium fuel to escape its cladding and become airborne.

\subsubsection{Reprocessing of Spent Fuel}

Spent fuel reprocessing is the mechanical and chemical processing of spent nuclear fuel to extract enriched uranium and plutonium from the fuel elements so they can be used in new fuel elements. Radioactive fission products are removed from the spent fuel and processed into high-level radioactive waste.

Currently, no reprocessing plants are licensed by NRC to operate in the U.S., nor are there any near term prospects for licensing any reprocessing plants. However, the Nuclear Fuel Services reprocessing plant in West Valley, New York, operated as a commercial plant under NRC license for many years, and reprocessing plants have been operating in the U.S. weapons program for over 40 years. In addition, reprocessing plants are operating in several foreign countries. 
Table 10. Calculated Releases and Doses from Spent Fuel Storage Accidents

\begin{tabular}{|c|c|c|c|c|c|c|}
\hline Reference & Accident & $\begin{array}{c}\mathrm{Kr}-85 \\
\text { Release }\end{array}$ & $\begin{array}{l}\text { Skin } \\
\text { Dose }\end{array}$ & $\begin{array}{l}\text { Effective Dose } \\
\text { Equivalent }\end{array}$ & I-129 Release & $\begin{array}{l}\text { Thyroid } \\
\text { Dose }\end{array}$ \\
\hline $\begin{array}{l}\text { Storage in pools: } \\
\text { Generic Environmental } \\
\text { Impact Statement, } \\
\text { NUREG- } 0575\end{array}$ & $\begin{array}{l}\text { Tornado driven } \\
\text { missile followed } \\
\text { by calm }\end{array}$ & $19,000 \mathrm{Ci}$ & $\begin{array}{l}0.06 \mathrm{rem} \\
\text { at } 275 \mathrm{~m}\end{array}$ & Not calculated & $0.00006 \mathrm{Ci}$ & $\begin{array}{l}0.03 \mathrm{rem} \\
\text { at } 275 \mathrm{~m}\end{array}$ \\
\hline $\begin{array}{l}\text { Storage in pools: } \\
\text { GE-Morris SER, } \\
\text { NUREG-0709 }\end{array}$ & $\begin{array}{l}\text { Drop of a fuel } \\
\text { storage basket }\end{array}$ & $6,000 \mathrm{Ci}$ & $\begin{array}{l}\text { Not } \\
\text { calculated }\end{array}$ & $\begin{array}{l}0.016 \text { rem } \\
\text { at } 150 \mathrm{~m}\end{array}$ & $0.00008 \mathrm{Ci}$ & $\begin{array}{l}0.0004 \mathrm{rem} \\
\text { at } 150 \mathrm{~m}\end{array}$ \\
\hline $\begin{array}{l}\text { Dry cask, drywe 11, } \\
\text { or dry vault } \\
\text { storage: NUREG-1140 }\end{array}$ & $\begin{array}{l}\text { Removal of cask } \\
\text { lid with all fuel } \\
\text { elements ruptured }\end{array}$ & $8,000 \mathrm{Ci}$ & $\begin{array}{l}\text { Not } \\
\text { calculated }\end{array}$ & $\begin{array}{l}0.003 \mathrm{rem} \\
\text { at } 100 \mathrm{~m}\end{array}$ & $0.004 \mathrm{Ci}$ & $\begin{array}{l}0.005 \text { to } \\
0.04 \text { rem } \\
\text { within } \\
100 \mathrm{~m} \\
\text { (child) }\end{array}$ \\
\hline
\end{tabular}




\subsubsection{Accident History}

The Nuclear Fuel Services reprocessing plant was plagued by many small releases into ground water, surface water, and air as well as unusually high occupational radiation exposures. However, the plant never had an accident of significance for offsite emergency preparedness.

Several criticality accidents, as listed in Table 5, have occurred in spent fuel reprocessing or in processes similar to those that would be used in spent fuel reprocessing plants.

No other accidents of significance offsite are known to have happened in spent fuel reprocessing.

\subsubsection{Accident Source Terms*}

Accident source terms for a reprocessing plant were analyzed in GESMO, and are quoted below.

"Upper level accidents that may occur at separations facilities or $\mathrm{PuO}_{2}$ conversion facilities include:

- Criticality

- High level radioactive waste concentrator or calciner explosion

- Plutonium product concentrator explosions

\section{Criticality Accident}

"A criticality accident is unlikely in a separations facility or $\mathrm{PuO}_{2}$ conversion facility, because equipment and process limitations are designed to prevent such incidents. Safe spacing is assured in storage basins by physically spacing the fuel elements in storage racks in a safe array. Process systems and controls are designed to prevent an unsafe condition. Nevertheless, a criticality accident of $10^{19}$ fissions is assumed. This yield is approximately an order of magnitude greater than the yield that has been experienced for $\mathrm{Pu}$ systems in past accidents. It is further assumed that all noble gases and $50 \%$

${ }^{\star}$ From GESM0, pages IV E-39 to IV E-42. 
of the halogens (or halides) are discharged from the plant stack. The dose commitments would be essentially the same for $\mathrm{UO}_{2}$ fuel or MOX fuel.

\section{Waste Concentrator Explosion Accident}

"During operation of the separation facility solvent extraction process, solvent degradation products are generated and may be carried over into the waste streams. Under extreme conditions in early pilot plant operations, these nitrated degradation products (red oil) have caused concentrator explosions. However, red oil explosions can be prevented by installing equipment to eliminate the accumulation of organic materials in the waste, and by controlling the process temperature in the concentrator.

"Concentrators are installed in highly shielded cells, having a volume of about $100,000 \mathrm{cu} \mathrm{ft}\left(3,000 \mathrm{~m}^{3}\right)$. In the unlikely event of an accident, the explosion is estimated to disperse about 150 gallons (600 liters) of high level radioactive waste solution into the cell in the form of a finely divided mist. A substantial portion of the mist would rain out or plate out on the cell surfaces. Droplets remaining in the air $\left(10 \mathrm{mg} / \mathrm{m}^{3}\right)$ would be carried through the ventilation ducts to the high efficiency filters. Moisture separators upstream of the filters would knock out most of the mist.

"The plant ventilation filters are located some distance from the separation plant process cells. Most of the explosive energy would be expended in destruction of the concentrator. Pressures developed by the explosion would be dampened by expansion into the cell and would be further attenuated in the ductwork. The final filters are not expected to be affected.

"It has been estimated that plateout of the droplets on the cell walls and floors and removal by the filtration system will result in a reduction in the fraction of material released to $3.6 \times 10^{-8}$. Material leaving the final filter has been estimated to be $30.5 \mathrm{mg}$ of high level radioactive waste solution in the form of an aerosol.

"Table IV E-16 identifies those nuclides that would contribute significantly to the offsite dose, and summarizes the offsite bone dose commitment that might result from this hypothetical accident. The maximum offsite dose commitment to an individual is estimated to be about $2.6 \mathrm{mrem}$ (bone) for $\mathrm{UO}_{2}$ fue 1 , and about 6.9 mrem (bone) for MOX fuels. 


\begin{tabular}{|c|c|c|c|c|c|}
\hline \multirow{3}{*}{ Nuclide } & \multirow{3}{*}{ Half Life } & \multicolumn{2}{|c|}{$\begin{array}{l}\text { "Table IV E-16 } \\
\text { VCENTRATION EXPLOSION EFFECT }\end{array}$} & \multirow{2}{*}{\multicolumn{2}{|c|}{$\begin{array}{c}\text { Accident Bone } \\
\text { Dose Contribution } \\
\text { mrem }\end{array}$}} \\
\hline & & \multicolumn{2}{|c|}{$\begin{array}{c}\text { Radioactivity Released } \\
\text { in Accident } \\
\mathrm{mCi} \\
\end{array}$} & & \\
\hline & & $\mathrm{UO}_{2}$ Fue 1 & MOX Fuel & $\mathrm{UO}_{2}$ Fuel & MOX Fue 1 \\
\hline $\mathrm{Pu}$ & & 0.02 & 0.15 & 0.01 & 0.06 \\
\hline $241 \mathrm{Am}$ & $458 y$ & 0.007 & 0.05 & 0.02 & 0.17 \\
\hline${ }^{242} \mathrm{Cm}$ & $162 d$ & 0.76 & 12.3 & 0.04 & 0.60 \\
\hline${ }^{244} \mathrm{Cm}$ & $18 y$ & 0.05 & 3.25 & 0.07 & 4.38 \\
\hline $90 \mathrm{Sr}$ & $29 y$ & 2.80 & 1.62 & 1.92 & 1.14 \\
\hline${ }^{106} \mathrm{Ru}$ & $1 y$ & 2000 & 3400 . & 0.02 & 0.04 \\
\hline${ }^{144} \mathrm{Ce}$ & $284 d$ & 27. & 23. & 0.04 & 0.03 \\
\hline Other F.P & & 1.5 & 1.5 & $\underline{0.48}$ & $\underline{0.48}$ \\
\hline & & & Total & 2.6 & 6.9 \\
\hline
\end{tabular}

"Table IV E-17 shows the radionuclide releases and the bone dose commitment to the maximally exposed offsite individual...

Table IV E-17

"PLUTONIUM PRODUCT EVAPORATOR EXPLOSION EFFECTS

Plutonium Radioactivity Released in Accident

\begin{tabular}{|c|c|c|c|}
\hline \multirow{2}{*}{ Isotope } & \multirow[b]{2}{*}{ Half Life } & \\
\hline & & $\mathrm{UO}_{2}$ Fuel & MOX Fuel \\
\hline 238 & $86 y$ & 1.02 & 2.11 \\
\hline 239 & $2.4 \times 10^{4} y$ & 0.08 & 0.04 \\
\hline 240 & $6,540 y$ & 0.11 & 0.13 \\
\hline 241 & $13 y$ & 2.94 & 4.01 \\
\hline
\end{tabular}

Total

Accident Bone Dose Contribution mrem

\begin{tabular}{|c|c|}
\hline \multicolumn{2}{|c|}{ mrem } \\
\hline $\mathrm{UO}_{2}$ Fuel & MoX Fuel \\
\hline 5.94 & 12.27 \\
\hline 0.51 & 0.28 \\
\hline 0.76 & 0.88 \\
\hline 3.98 & 5.42 \\
\hline 11.2 & 18.9 \\
\hline
\end{tabular}




\section{Plutonium Concentrator Explosion Accident}

"The postulated explosion of a plutonium concentrator in the reprocessing plant is typical of upper level accidents by which plutonium could be released to a cell or glovebox area. Typically, the plutonium processing equipment tends to be smaller, and installed in smaller rooms (cells or gloveboxes) than the waste concentrator previously discussed. The release rate is derived by assuming that the room (cell or glovebox) atmosphere contains the same mass of aerosol $\left(10 \mathrm{mg} / \mathrm{m}^{3}\right)$ as the atmosphere of the waste concentrator cell. For a $1,000 \mathrm{~m}^{3}$ plutonium concentrator cell volume, the postulated accident would release about $2.2 \mathrm{mg}$ of plutonium.

\subsubsection{Calculations of Doses}

The doses below for these accidents are taken directly from GESMO, page IV $\mathrm{E}-40$.

\section{"Maximum Offsite Individual Dose Commitment (rem)}

Accident

Criticality

Waste Concentrator Explosion

Pu Evaporator Explosion

Fire
PWR MOX Fuel

0.056 (thyroid)

0.0069 (bone)

0.019 (bone)

0.0135 (bone)

End of Quote

\subsubsection{Implications for Emergency Preparedness}

According to the GESMO analysis accidents at reprocessing plants would not cause doses in excess of protective action guides. This is primarily due to lack of strong driving forces and extensive containment systems. Thus special emergency preparedness is not needed offsite.

\subsubsection{Research with Nuclear Fuels}

These facilities perform research and development related to nuclear power plant fuel manufacturing and testing. They use special nuclear materials 
in forms ranging from powders to solutions, al though larger quantities are usually in the form of fuel pellets. The work takes place in laboratories and glove box trains. Processes such as blending, crushing, milling, sintering, grinding, and solvent extraction may take place.

\subsubsection{Accident History}

A number of the accidents previously discussed for other parts of the fuel cycle are relevant to research with nuclear fuels. For example, if the facility handles large quantities of enriched uranium, criticalities as listed in Table 5 could occur. In addition, fires and other types of accidents such as those listed in Tables 6 and 7 could occur. Since these types of accidents have been discussed previously, they will not be discussed further here.

\subsubsection{Accident Source Terms}

Sutter* has analyzed nuclear fuel research facilities and concluded that the potential accidents are criticality accidents, spills and leaks, tornados, earthquakes, fires outside the facility, fires inside the facility, explosions, and fuel handling accidents.

If large quantities of material are handled a criticality accident may be a possibility. If this is the case, the releases and offsite doses would be the same as those discussed in Section 2.2.5.2 for criticalities at fuel fabrication plants.

The other possible accidents of significance would be a major fire in the facility such as a fire in a glove box train. If the fire does not break the glove box filters and the final HEPA filters, the release to the environment would be negligible. However, if both sets of filters are breached a considerable release is plausible. Assuming 13 glove boxes are in the train, $2 \mathrm{~kg}$ of material is present in each, and $0.1 \%$ becomes airborne due to the fire, a release of $0.026 \mathrm{~kg}$ would be calculated. This would be uranium or plutonium, whichever was being processed, although at this time no licensees are handling such quantities of plutonium.

\footnotetext{
*Sutter, Op. cit.
} 


\subsubsection{Calculations of Doses}

Doses due to a criticality would be the same as discussed previously. A fire involving low enriched uranium (solubility class $Y$ ) would result in an effective dose equivalent within $100 \mathrm{~m}$ of $0.007 \mathrm{rem}$ for $\mathrm{F}, 1 \mathrm{~m} / \mathrm{s}$ meteorology and 0.001 rem for more typical $D, 4.5 \mathrm{~m} / \mathrm{s}$ meteorology. Inhaled quantities are well below levels where chemical toxicity is observed. The dose calculations assumed that the building size was $25 \mathrm{~m} \times 10 \mathrm{~m}$, the release was at ground level, and the release duration was 30 minutes.

If plutonium-239 were the fuel rather than uranium, the effective dose equivalent from the fire would be about 67 rems for typical $D, 4.5 \mathrm{~m} / \mathrm{s}$ meteorology and 500 rems for conservative $F, 1 \mathrm{~m} / \mathrm{s}$ meteorology. The dose calculations for uranium and plutonium consider an insoluble class $Y$ compound. However, the plutonium dose was calculated assuming that plutonium facility would have the same containment capability as uranium facilities would be expected to have. Since superior containment is provided for plutonium, the offsite doses presented here are probably larger that could actually be by quite a large margin. For example, we assume $0.1 \%$ release for the involved plutonium. By comparison the actual release for the Rocky Flats fire discussed previously was $10^{-8}$, a hundred-thousand times lower.

\subsubsection{Implications for Emergency Preparedness}

Criticality, as discussed previously, may require some emergency preparedness. Other accidents at facilities handling uranium would not seem to require emergency preparedness. Plutonium processing, on the other hand could cause large doses offsite if not contained. We therefore conclude that for plutonium research and development activities the need for offsite emergency preparedness should be evaluated on a case by case basis.

\subsection{Byproduct Material Facilities}

There are six types of byproduct material licensees that handle large enough quantities of radioactive material not in sealed form so that need for offsite emergency preparedness should be considered. These are: radiopharmaceutical manufacturing, radiopharmacies, sealed source manufacturing, 
university research laboratories, waste warehousing, and fabrication of depleted uranium products.

\subsubsection{A Generic Overview}

We will consider each of these types of facilities separately rather than as a single group. The reason is that we wish to determine whether accident scenarios and release fractions developed for each type can be generalized into a single set of accident scenarios and release fractions. But first, we will consider certain common or generic characteristics of byproduct material 1 icensees.

\subsubsection{Accident History}

The accidents involving release of byproduct material from all types of facilities handling byproduct material are listed below in Tables 11 and 12 . The reason for combining all types of facilities in these tables is that the experience of one type of facility may be relevant to other types of facilities. For example, a fire or explosion in a glovebox or hot cell is an accident that could happen at almost any type of major byproduct handling facility. The relevant accidents listed in Tables 11 and 12 will be discussed in later sections.

Overall, accidents involving byproduct material have led to small offsite doses. Releases have always been below the EPA's protective action guide lower limit of 1 rem. Thus, no emergency protective actions have ever been necessary to protect people offsite from airborne releases of radioactivity.

\subsubsection{Release Fractions for Accident Source Terms*}

The release fractions selected are given below along with the reasons for selecting them.

Noble gases (1.0): $\mathrm{Kr}$ and $\mathrm{Xe}$ were assigned a release fraction of 1 because they are always gases at room temperature, they do not plate out, they are not retained by filters, and they do not react chemically to form less volatile compounds.

*This section prepared with the assistance of Mark Halverson, Pacific Northwest Laboratory, who compiled the references upon which the release fractions are based. 
Table 11. Fires and Explosions Involving Release of Byproduct Materials through 1986

\begin{tabular}{|c|c|c|c|}
\hline Date & Facility & Release & Description \\
\hline $4-23-50$ & $\begin{array}{l}\text { Lawrence Radiation } \\
\text { Lab, S.F., CA }\end{array}$ & Minor & $\begin{array}{l}\text { Multistory research build- } \\
\text { ing destroyed by fire. }\end{array}$ \\
\hline $2-21-55$ & AEC Contractor & Minor & $\begin{array}{l}\text { Spontaneous ignition fire } \\
\text { broke out in nitric acid } \\
\text { saturated rags and paper } \\
\text { in a contaminated waste } \\
\text { storage area of a chemical } \\
\text { process laboratory. }\end{array}$ \\
\hline $10-8-59$ & $\begin{array}{l}\text { Mound Laboratory, } \\
\text { Miamisburg, OH } \\
\text { (Fuel R\&D) }\end{array}$ & $\begin{array}{l}\text { Po- } 210 \\
\text { contamination } \\
\text { in laboratory. } \\
39 \mathrm{C} i \text { released } \\
\text { onsite }\end{array}$ & $\begin{array}{l}\text { Explosion in drybox } \\
\text { disperses Po- } 210 \text {. Lab tech } \\
\text { combined acetone wash with } \\
\text { nitric acid solution. }\end{array}$ \\
\hline $11-10-60$ & $\begin{array}{l}\text { Laboratory at } \\
\text { Univ. of Calif., } \\
\text { Berkeley, CA }\end{array}$ & None & $\begin{array}{l}\text { An overheated oil both } \\
\text { started a fire in a process- } \\
\text { ing cave handling curium. } \\
\text { No exposures and no contami- } \\
\text { nation outside cave. }\end{array}$ \\
\hline $12-29-60$ & $\begin{array}{l}\text { University of } \\
\text { Alabama } \\
\text { (Laboratory) }\end{array}$ & Some & $\begin{array}{l}\text { Fire caused loss of some } \\
\text { radioactive materials. }\end{array}$ \\
\hline $4-5-61$ & $\begin{array}{l}\text { U.S. (location } \\
\text { unspecified) }\end{array}$ & $\begin{array}{l}1 \text { mCi. Minor } \\
\text { contamination }\end{array}$ & $\begin{array}{l}\text { Radiochemistry building } \\
\text { fire. }\end{array}$ \\
\hline $9-25-64$ & $\begin{array}{l}\text { AEC } \\
\text { contractor }\end{array}$ & $\begin{array}{l}2.5 \mathrm{~g} \text { of } \\
\text { americium }\end{array}$ & $\begin{array}{l}\text { Shipping container } \\
\text { explosion. }\end{array}$ \\
\hline $4-20-69$ & $\begin{array}{l}\text { Babcock and } \\
\text { Wilcox }\end{array}$ & $\begin{array}{l}\text { Co- } 60 \\
\text { contamination } \\
\text { of incinerator } \\
\text { of } 10 \mathrm{mR} / \mathrm{hr}\end{array}$ & $\begin{array}{l}\text { A bag of Co- } 60 \text { contaminated } \\
\text { paper was put in nonradio- } \\
\text { active trash and burned in } \\
\text { incinerator. }\end{array}$ \\
\hline $8-30-76$ & $\begin{array}{l}\text { Hanford Site - } \\
\text { Plutonium } \\
\text { Plant }\end{array}$ & $\begin{array}{l}300 \text { Ci Am- } 241 \\
\text { Worker seriously } \\
\text { contaminated. } \\
\text { Negligible } \\
\text { release to } \\
\text { environment. }\end{array}$ & $\begin{array}{l}\text { Explosion of an ion } \\
\text { exchange column containing } \\
100 \mathrm{~g}(300 \mathrm{Ci}) \text { of Am- } 241 \text {. } \\
1 \text { to } 5 \mathrm{Ci} \text { deposited on a } \\
\text { worker's skin and clothing. } \\
5 \mathrm{mCi} \text { remained on body } \\
\text { after initial washing. } \\
\text { Inhalation uptake by lung } \\
\text { estimated at } 0.05 \mathrm{mC} \text {. }\end{array}$ \\
\hline
\end{tabular}


Table 12. Accidental Releases of Byproduct Material Except Fires and Explosions through 1986

\begin{tabular}{|c|c|c|c|}
\hline Date & Facility & Release & Description \\
\hline $7-25-58$ & $\begin{array}{l}\text { Los Alamos } \\
\text { Scientific Lab. } \\
\text { Los Alamos, NM }\end{array}$ & $\mathrm{H}-3$, minor & H-3 gas escaped. \\
\hline $8-24-62$ & $\begin{array}{l}\text { Phillips Petroleum } \\
\text { Co., Idaho Reactor } \\
\text { Test Site, Idaho } \\
\text { Falls, ID }\end{array}$ & $\begin{array}{l}\mathrm{I}-131 \text { leaked } \\
\text { from cask. } \\
\text { Dose of } 5 \mathrm{R} / \mathrm{hr} \\
\text { on surface }\end{array}$ & $\begin{array}{l}\text { Leaky shipping cask contaminated } \\
\text { truck and cask. }\end{array}$ \\
\hline $1-23-64$ & $\begin{array}{l}\text { Hanford Laboratory, } \\
\text { Richland, WA }\end{array}$ & $S r-90$ & $\begin{array}{l}\text { While workers were replacing } \\
\text { an agitator on a waste storage } \\
\text { tank, convection currents } \\
\text { carried contaminated vapor from } \\
\text { the open top of the tank to the } \\
\text { environment. }\end{array}$ \\
\hline $1-15-67$ & $\begin{array}{l}\text { Babcock and Wilcox, } \\
\text { Apol10, PA }\end{array}$ & Ir-192 onsite & $\begin{array}{l}\text { Technicians cut into an Ir-192 } \\
\text { pellet in hot cell. Ventilation } \\
\text { imbalance allowed Ir-192 to } \\
\text { escape to working area. }\end{array}$ \\
\hline $4-4-67$ & $\begin{array}{l}\text { Savannah River } \\
\text { Laboratory, } \\
\text { Aiken, SC }\end{array}$ & $\begin{array}{l}\mathrm{H}-3 \text { released } \\
\text { through stack. } \\
\text { Minor }\end{array}$ & $\begin{array}{l}\text { An electric welder malfunctioned } \\
\text { causing the failure of a seal } \\
\text { tube which released } \mathrm{H}-3 \text { to } \\
\text { stack. }\end{array}$ \\
\hline $9-27-68$ & $\begin{array}{l}\text { U.S. (location } \\
\text { not reported) }\end{array}$ & $\begin{array}{l}\text { Low level } \\
\text { waste } \\
\text { contamination }\end{array}$ & $\begin{array}{l}\text { A cask of canned waste was } \\
\text { dumped into an underground } \\
\text { caisson. Radioactive dust } \\
\text { escaped contaminating the cask, } \\
\text { its truck, and workers. }\end{array}$ \\
\hline $5-5-69$ & $\begin{array}{l}\text { U.S. Naval Ammuni- } \\
\text { tion Facility }\end{array}$ & $\begin{array}{l}\text { Minor quantity } \\
\text { of } \mathrm{Kr}-85\end{array}$ & Released to atmosphere \\
\hline $8-6-70$ & $\begin{array}{l}\text { Lawrence Radiation } \\
\text { Laboratory, } \\
\text { Berkeley, CA }\end{array}$ & $\begin{array}{l}\text { H-3 acci- } \\
\text { dentally } \\
\text { discharged } \\
\text { through } \\
\text { 100-ft stack }\end{array}$ & $\begin{array}{l}\text { Automatic safety devices } \\
\text { failed. }\end{array}$ \\
\hline $9-17-73$ & $\begin{array}{l}\text { Rocky Flats, } \\
\text { Golden, } \mathrm{CO}\end{array}$ & $\begin{array}{l}\mathrm{H}-3 \text { released } \\
\text { to water }\end{array}$ & $\begin{array}{l}\text { Water not known to be contam- } \\
\text { inated with } \mathrm{H}-3 \text { released to } \\
\text { plant waste stream. }\end{array}$ \\
\hline $5-2-74$ & $\begin{array}{l}\text { Savannah River } \\
\text { Laboratory, } \\
\text { Ailen, SC }\end{array}$ & $\mathrm{H}-3,50 \mathrm{~g}$ & $\begin{array}{l}\text { Failure of a pipe fitting } \\
\text { al lowed } \mathrm{H}-3 \text { to be discharged } \\
\text { through stack. }\end{array}$ \\
\hline
\end{tabular}


Table 12. (continued)

\begin{tabular}{|c|c|c|c|}
\hline Date & Facility & Release & Description \\
\hline $\begin{array}{l}1978 \\
\text { calendar } \\
\text { year }\end{array}$ & $\begin{array}{l}\text { American Atomics } \\
\text { Corp, Phoenix, AZ }\end{array}$ & $\begin{array}{l}287,000 \mathrm{Ci} \\
\text { of } \mathrm{H}-3\end{array}$ & $\begin{array}{l}\text { "Normal operating losses," Some } \\
\text { food prepared nearby contained } \\
H-3 \text { in concentrations above } \\
\text { EPA drinking water standard } \\
\text { of } 0.02 \text { uCi/l ( } 4 \text { mrem/yr for } \\
2 \text { liter/day consumption). (This } \\
\text { was not an accidental release, } \\
\text { but is included because of the } \\
\text { large quantity of material } \\
\text { released.) }\end{array}$ \\
\hline $9-1-80$ & $\begin{array}{l}\text { New England Nuclear, } \\
\text { N. Billerica, MA }\end{array}$ & $\begin{array}{l}\text { Am-241 inside } \\
\text { plant }\end{array}$ & $\begin{array}{l}\text { Airborne Am- } 241 \text { while renovating } \\
\text { contaminated gloveboxes. }\end{array}$ \\
\hline $7-24-81$ & $\begin{array}{l}\text { New England Nuclear, } \\
\text { N. Billerica, MA }\end{array}$ & $3.2 \mathrm{Ci}$ of $\mathrm{S}-35$ & $\begin{array}{l}\text { Released during opening of } \\
2 \text { capsules containing } 30 \mathrm{Ci} \\
\text { of } \mathrm{S}-35 \text {. }\end{array}$ \\
\hline $\begin{array}{l}11-19-81 \\
12-12-81\end{array}$ & $\begin{array}{l}\text { Tech/Ops, } \\
\text { Burlington, MA }\end{array}$ & $\begin{array}{l}\text { Ir-192 } \\
\text { surface }\end{array}$ & $\begin{array}{l}\text { Ir-192 surface contamination } \\
\text { found in lab. Escape path from } \\
\text { hot cells not discovered. }\end{array}$ \\
\hline $8-27-82$ & $\begin{array}{l}\text { Consolidation Coal } \\
\text { Company, Library, } \\
\text { PA }\end{array}$ & $\begin{array}{l}\text { Up to } 0.5 \mathrm{Ci} \\
\text { of Am-241 in } \\
\text { drilling mud }\end{array}$ & $\begin{array}{l}\text { A stuck well logging source } \\
\text { was cut by a drill bit during } \\
\text { recovery operations. Because } \\
\text { the leak went unrecognized, } \\
\text { some Am-241 activity was } \\
\text { tracked into homes and } \\
\text { businesses. }\end{array}$ \\
\hline $2-8-83$ & $\begin{array}{l}\text { Gulf Nuclear, Inc. } \\
\text { Webster, TX }\end{array}$ & $\begin{array}{l}\text { Am-241 inside } \\
\text { plant }\end{array}$ & $\begin{array}{l}\text { A } 20 \mathrm{Ci} \text { Am- } 241 \text { sealed source was } \\
\text { accidentally cut open on a cut } \\
\text { open on a lathe during machining } \\
\text { Six employees were exposed. }\end{array}$ \\
\hline $9-13-83$ & $\begin{array}{l}\text { Shelwell Services, } \\
\text { Inc., Hebron, } \mathrm{OH}\end{array}$ & $\begin{array}{l}\text { Cs-137 on } \\
\text { workers shoes } \\
\text { and clothing }\end{array}$ & $\begin{array}{l}2 \mathrm{Ci} C s-137 \text { sealed source cut } \\
\text { open on lathe. Some CsCl powder } \\
\text { spilled out. Shop contaminated. } \\
15 \text { homes contaminated by } \mathrm{Cs}^{-137} \\
\text { from workers shoes and clothing. }\end{array}$ \\
\hline
\end{tabular}


Volatile and combustible compounds (0.5): A release fraction of 0.5 was assigned to volatile and combustible elements and compounds, for example, hydrogen, phosphorous, sulfur, iodine, bromine, and chlorine. Releases of these materials would be expected to be less than $100 \%$ due to these factors: (1) some of the compounds of the elements may form some nonvolatile compounds (ash) in a fire, (2) some of the compounds of the elements will plate out and deposit on internal surfaces, (3) some of compounds of the elements will be subject to retention by filters, (4) not a11 containers possessed by a licensee would be likely to be breached in an accident, (5) at any particular time the actual inventory may be below the licensed possession limit, and (6) some particles formed may not be respirable. Consideration of site specific factors could cause considerable reductions in the release fractions for specific facilities.

With respect to I-131, experimental releases from a fire with the I-131 in a flammable solvent were $65 \%$. If the container was subsequently heated afterwards with a propane torch the release reached $83 \%$. 0 other factors as mentioned above would reduce the quantity that would actually escape the building.

The elements listed above could be used in nonvolatile and noncombustible forms, for example, the chlorine in sodium chloride. For those situations, the licensee would have to apply for a site-specific release fraction based on the chemical forms used.

Carbon (0.01): Carbon compounds are generally combustible. However, most of the carbon would be emitted as carbon dioxide. Carbon dioxide is relatively inert and is not significantly deposited in the lungs or on surfaces. Thus, carbon dioxide containing radioactive carbon is of little biological significance compared to other forms of carbon. We have assumed that the release fraction for carbon in forms other than carbon dioxide is 0.01 , the value given below for semi-volatile compounds.

Semi-volatile compounds $(0.01)$ : These include compounds of the elements selenium, mercury, cesium, polonium, tellurium, and ruthenium. Releases of Cs-137 at $1000^{\circ} \mathrm{C}$ have been measured at $1 \% / \mathrm{hr},{ }^{*} 1.5 \% / \mathrm{hr},{ }^{* *}$ and $4.2 \% / \mathrm{hr}$. $\dagger$

\footnotetext{
*A. E. Albrethsen and L. C. Schendiman, "Volatilization of Fission Products from High-Level Wastes," BNWL338, Pacific Northwest Laboratory, 1967.

**W. J. Gray, "Volatility of a Zinc Borosilicate Glass Containing Simulated High-Level Radioactive Waste," BNWL-2111, Pacific Northwest Laboratory, 1969.

†D. Walmsley et al, "Volatility Studies of Glasses for the Fingal Process, AERE-R-5779, England, 1969.
} 
Additional removal by filter retention and condensation was measured at 35 to 93\% removal, and an additional $30 \%$ removal by deposition was measured.* Polonium-20 is generally found in a liquid, with a bismuth metal slug, or bound to ceramic microspheres. These forms of polonium-210 should generally have a relatively low release fraction. Based on the assumption of a 30-minute fire, an assumed release fraction of 0.01 is believed to be reasonable for semivolatile compounds.

Unknown form (but not generally volatile or combustible) (0.01): For use in screening analyses in which the chemical form of a radioactive material is not known, a release fraction of 0.01 is assumed. This value does not apply to $\mathrm{Kr}, \mathrm{Xe}, \mathrm{H}, \mathrm{C}, \mathrm{P}$, or $\mathrm{S}$, which were assigned different values above. It does not apply to $U, \mathrm{Pu}, \mathrm{Am}$, or $\mathrm{Cm}$, which are assigned a release fraction of 0.001 on the basis of their general form as nonvolatile powders as explained below. It also does not apply to $\mathrm{Co}, \mathrm{Ta}$, and $\mathrm{Ir}$, which are assigned a release fraction of 0.001 , as explained below.

The 0.01 release factor for unknown form should be used only for screening. For specific facilities, the actual chemical form of the radioactive material could be used to determine an appropriate (generally lower) release fraction.

Nonvolatile powders (0.001): Release fractions for nonvolatile compounds are given as the fraction of material released which is of respirable size. Most experiments report total release fraction. To convert these to respirable release fraction, the release of particles larger than 10 microns was excluded from the respirable release fraction. Most reported experiments provide enough information to allow this determination, but some do not. For experiments providing no information on particle size, it is necessary to estimate respirable release fractions from total release fractions by assuming that the respirable proportion will be similar to that reported in similar experiments.

A release fraction of 0.001 was assigned to nonvolatile compounds in powder form. The mechanism is not volatilization. Rather it is entrainment of the particles in an airstream. Even finely ground powders will generally contain less than a few percent of the powder in respirable size. The fraction of particles of respirable size is kept small by the difficulty in producing all small particles and subsequently by agglomeration and weathering,

$*_{R}$. K. Hilliard, "Fission Product Release from Uranium Heated in Air," HW-60689, Hanford Atomic Products Operation, 1959. 
processes which cause micron-sized particles to stick to surfaces, to larger particles, and to themselves. Particles larger than respirable size ( $>10$ microns aerodynamic median diameter) quickly settle out of the air, and if inhaled seldom are deposited in the lungs.

The release fraction of 0.001 is suggested by a number of experiments generally designed to maximize the release.* The experiments usually found releases of respirable size particles of about 0.001 or less. In a few special cases designed to produce maximum releases, values above 0.001 were found. These conditions were for highly ground powders on certain flammable surfaces such as rubber or plexiglass, for high velocity air flow, or for highly pressurized releases in which all the material is violently thrown into the air, which is then sampled before significant settling can occur. Such conditions are not considered representative of realistic accident conditions.

Uranium metal and plutonium metal (0.001): These materials are pyrophoric. The release fraction of 0.001 is representative of experimental measurements described in Section 2.3.7.2.

Nonvolatile solids (0.0001): For nonvolatile compounds in solid form rather than powder form, a release fraction of 0.0001 was assumed to reflect the lower amount of material that would be of respirable size. This value could be applied to cobalt, iridium, and tanalum in solid form on a case by case basis.

Nonvolatile elements in flammable liquids $(0.005)$. A release fraction of 0.005 was assigned to nonvolatile compounds in flammable liquids.

Experiments with strontium in a flammable solvent yielded a release fraction of 0.002 from a fire.**

Releases of uranium in flammable solvent averaged 0.00025 , releases of cesium averaged 0.0024 , releases of cerium averaged 0.0065 , and releases of zirconium also averaged 0.0065 .** When the container in those experiments were

\footnotetext{
*J. Mishima, L. Schwendiman, and Radasch, "Plutonium Release Studies III. Release from Heated Plutonium Bearing Powers," BNWL-786, Pacific Northwest Laboratory, Richland, WA, 1968.

J. Mishima and L. Schwendiman, "Fractional Airborne Release of Uranium (Representing Plutonium) During the Burning of Contaminated Wastes," BNWL1730, Pacific Northwest Laboratory, Richland, WA, 1973.

S. Sutter, Johnson, and J. Mishima, "Aerosols Generated by Free Fall Spills of Powders and Solutions in Static Air," PNL, NUREG/CR-2139, PNL-3786, 1981.

**S. L. Sutter et al, "Fractional Airborne Release of Strontium During the Combustion of $30 \%$ Normal Tributyl Phosphage in a Kerosine Type Diluent," BNWL-B-358, Pacific Northwest Laboratory, 1974.
} 
subsequently heated with a propane torch uranium releases were 0.003 , cesium releases averaged 0.006 , cerium releases averaged 0.0074 , and zirconium averaged 0.004.*

For $\mathrm{UO}_{2}$ powder in gasoline, release fractions were 0.0012 when airflow was $1.8 \mathrm{~m} / \mathrm{s}$.** of this, $66 \%$ was less than 10 micron AED*** for a respirable release fraction of 0.0008 . When airflow increased to $8.9 \mathrm{~m} / \mathrm{s}$, the release fraction increased to 0.013 , $^{*}$ but only $7 \%^{* *}$ was smaller than 10 microns, thus the respirable release fraction was 0.0009 , about the same as with the lower airflow.

In other experiments on burning of kerosene-based solvent releases of Ru-106 were below $0.1 \%$ and releases of uranium and plutonium were much lower. $\dagger$

Nonvolatile compounds in nonflammable liquids $(0.001)$ : Nonvolatile compounds in nonflammable liquids are assigned a release fraction of 0.001 . Several studies have measured releases in these circumstances. In general, release of these compounds can be expected to be small until the liquid is dried. After drying release fractions generally remain small because the material normally cakes on the substrate or binds into particles too large to be respirable.

\subsubsection{Quantities Requiring Consideration of Emergency Preparedness}

Table 13 lists the quantities requiring consideration of emergency preparedness based on the quantities needed to deliver a 1-rem effective dose equivalent offsite. The quantities $Q_{i}$ in Table 13 were calculated using the following equation:

$$
Q_{i}=\frac{1}{R_{i}\left(H_{I i}+H_{G C i}+H_{C S i}\right)}
$$

\footnotetext{
*J. Mishima and L. C. Schwendiman, BNWL-B-274, 1973, op.cit.

$* *$ J. Mishima and L. C. Schwendiman, BNWL-1730.

***J. Mishima and L. C. Schwendiman, BNWL-1732.

$\dagger D$. Whitney Tharin, Jr., "Burning of Radioactive Process Solvent, Savannah

River Laboratory Report DP-942, Aiken, South Carolina, 1965.
} 
Table 13. Quantities of Radioactive Materials Requiring Evaluation of the Need for Offsite Emergency Preparedness. (Based on 1 rem effective dose equivalent outside the building.)

\begin{tabular}{|c|c|c|c|c|c|}
\hline $\begin{array}{l}\text { Radioactive } \\
\text { material }\end{array}$ & $\begin{array}{l}\text { Dose conver- } \\
\text { sion factor } \\
\text { (rems/uCi } \\
\text { inhaled)* }\end{array}$ & $\begin{array}{l}\text { Solubility } \\
\text { class** }\end{array}$ & $\begin{array}{l}\text { Release } \\
\text { fraction }\end{array}$ & $\begin{array}{l}\text { Quantity } \\
\text { (weight) }\end{array}$ & $\begin{array}{l}\text { Quantity } \\
\text { (curie) }\end{array}$ \\
\hline $\mathrm{H}-3$ & .00012 & - & 0.5 & & 20,000 \\
\hline$c-14$ & .0021 & - & 0.01 & $\left.n \mathrm{CO}_{2}\right)$ & 50,000 \\
\hline $\mathrm{Na}-22$ & .0076 & $D$ & 0.01 & & 9,000 \\
\hline $\mathrm{Na}-24$ & .0012 & D & 0.01 & & 10,000 \\
\hline$P-32$ & .015 & $W$ & 0.5 & & 100 \\
\hline$P-33$ & .0023 & $W$ & 0.5 & & 1,000 \\
\hline$S-35$ & .0025 & - & 0.5 & & 900 \\
\hline$C 1-36$ & .022 & $W$ & 0.5 & & 5,000 \\
\hline$K-40$ & .012 & D & 0.5 & & 50,000 \\
\hline$K-42$ & .0014 & D & 0.01 & & 9,000 \\
\hline $\mathrm{Ca}-45$ & .0065 & $W$ & 0.01 & & 20,000 \\
\hline $\mathrm{Sc}-46$ & .029 & $Y$ & 0.01 & & 3,000 \\
\hline $\mathrm{Ti}-44$ & 1.0 & $Y$ & 0.01 & & 100 \\
\hline$V-48$ & .010 & $W$ & 0.01 & & 7,000 \\
\hline $\mathrm{Cr}-51$ & .00033 & $\ddot{Y}$ & 0.01 & & 300,000 \\
\hline$M n-54$ & .0067 & $W$ & 0.01 & & 10,000 \\
\hline$M n-56$ & .00037 & D & 0.01 & & 60,000 \\
\hline $\mathrm{Fe}-55$ & .0027 & D & 0.01 & & 40,000 \\
\hline $\mathrm{Fe}-59$ & .015 & D & 0.01 & & 7,000 \\
\hline Co-60 & .22 & $Y$ & 0.001 & & 5,000 \\
\hline $\mathrm{Ni}-63$ & .0063 & - & 0.01 & & 20,000 \\
\hline Cu-64 & .00027 & $Y$ & 0.01 & & 200,000 \\
\hline$Z n-65$ & .02 & $Y$ & 0.01 & & 5,000 \\
\hline $\mathrm{Ge}-68$ & .051 & $W$ & 0.01 & & 2,000 \\
\hline $\mathrm{Se}-75$ & .0084 & $W$ & 0.01 & & 10,000 \\
\hline $\mathrm{Kr}-85$ & - & - & 1.0 & & $6,000,000$ \\
\hline $\mathrm{Rb}-86$ & .0066 & D & 0.01 & & 20,000 \\
\hline$S r-89$ & .041 & $Y$ & 0.01 & & 3,000 \\
\hline$S r-90$ & 1.3 & $Y$ & 0.01 & & 90 \\
\hline$Y-91$ & .048 & $Y$ & 0.01 & & 2,000 \\
\hline$Z r-93$ & .32 & D & 0.01 & & 400 \\
\hline Zr-95 & .024 & D & 0.01 & & 5,000 \\
\hline
\end{tabular}

*This column is also roughly equal to the maximum dose in rems per curie released because the maximum intercept fraction is $10^{-6}$ and the inhalation pathway dominates the dose for most materials.

** Solubility classes for materials in the lung as defined in ICRP Publication 30. $D=$ days, $W=$ weeks, and $Y=$ years . 
Table 13. (continued)

\begin{tabular}{|c|c|c|c|c|c|}
\hline $\begin{array}{l}\text { Radioactive } \\
\text { material }\end{array}$ & $\begin{array}{l}\text { Dose conver- } \\
\text { sion factor } \\
\text { (rems/uCi } \\
\text { inhaled) }\end{array}$ & $\begin{array}{l}\text { Solubility } \\
\text { class }\end{array}$ & $\begin{array}{l}\text { Release } \\
\text { fraction }\end{array}$ & $\begin{array}{l}\text { Quantity } \\
\text { (weight) }\end{array}$ & $\begin{array}{l}\text { Quantity } \\
\text { (curie) }\end{array}$ \\
\hline $\begin{array}{l}\mathrm{Nb}-94 \\
\mathrm{Nb}-95 \\
\mathrm{Mo}-99 \\
\mathrm{~T} c-99 \\
\mathrm{Tc}-99 \mathrm{~m} \\
\mathrm{Ru}-103 \\
\mathrm{Ru}-105 \\
\mathrm{Ru}-106 \\
\mathrm{Ag}-110 \mathrm{~m} \\
\mathrm{Cd}-109 \\
\mathrm{Cd}-113 \mathrm{~m} \\
\mathrm{In}-114 \mathrm{~m} \\
\mathrm{Sn}-113 \\
\mathrm{Sn}-123 \\
\mathrm{Sn}-126 \\
\mathrm{Sb}-124 \\
\mathrm{Sb}-126 \\
\mathrm{Te}-127 \mathrm{~m} \\
\mathrm{Te}-129 \mathrm{~m} \\
\mathrm{I}-125 \\
\mathrm{I}-129 \\
\mathrm{I}-131 * \\
\mathrm{Xe}-133 \\
\mathrm{Cs}-134 \\
\mathrm{Cs}-137 \\
\mathrm{Ba}-133 \\
\mathrm{Ba}-140 \\
\mathrm{Ce}-141 \\
\mathrm{Ce}-144 \\
\mathrm{Pm}-145 \\
\mathrm{Pm}-147 \\
\mathrm{Sm}-151 \\
\mathrm{Eu}-152 \\
\mathrm{Eu}-154 \\
\mathrm{Eu}-155 \\
\mathrm{Gd}-153 \\
\mathrm{~Tb}-160 \\
\mathrm{Ho}-166 \mathrm{~m} \\
\mathrm{Tm}-170 \\
\mathrm{Yb}-169 \\
\mathrm{Hf}-172 \\
\mathrm{Hf}-181 \\
\mathrm{Ta}-182\end{array}$ & 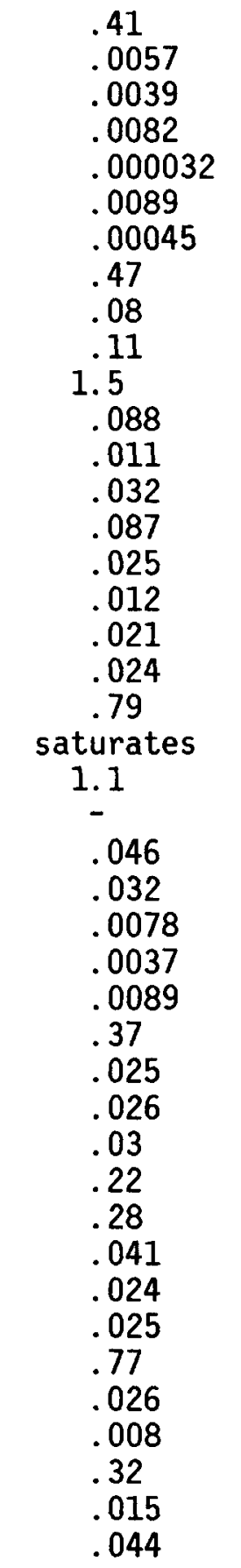 & $\begin{array}{l}Y \\
Y \\
Y \\
W \\
D \\
Y \\
Y \\
Y \\
Y \\
D \\
D \\
D \\
W \\
W \\
W \\
W \\
W \\
W \\
W \\
D \\
- \\
D \\
- \\
D \\
D \\
D \\
D \\
Y \\
Y \\
W \\
W \\
W \\
W \\
W \\
W \\
D \\
W \\
W \\
W \\
Y \\
D \\
D \\
Y\end{array}$ & $\begin{array}{l}0.01 \\
0.01 \\
0.01 \\
0.01 \\
0.01 \\
0.01 \\
0.01 \\
0.01 \\
0.01 \\
0.01 \\
0.01 \\
0.01 \\
0.01 \\
0.01 \\
0.01 \\
0.01 \\
0.01 \\
0.01 \\
0.01 \\
0.5 \\
0.5 \\
0.5 \\
0.5 \\
1.0 \\
0.01 \\
0.01 \\
0.01 \\
0\end{array}$ & & $\begin{array}{r}300 \\
10,000 \\
30,000 \\
10,000 \\
400,000 \\
10,000 \\
70,000 \\
200 \\
1,000 \\
1,000 \\
80 \\
1,000 \\
10,000 \\
3,000 \\
1,000 \\
4,000 \\
6,000 \\
5,000 \\
5,000 \\
7 \\
\text { infinite } \\
5 \\
900,000 \\
2,000 \\
3,000 \\
10,000 \\
30,000 \\
10,000 \\
300 \\
4,000 \\
4,000 \\
4,000 \\
500 \\
400 \\
3,000 \\
5,000 \\
4,000 \\
100 \\
4,000 \\
10,000 \\
400 \\
7,000 \\
20,000\end{array}$ \\
\hline
\end{tabular}

*Child's thyroid. 
Table 13. (continued)

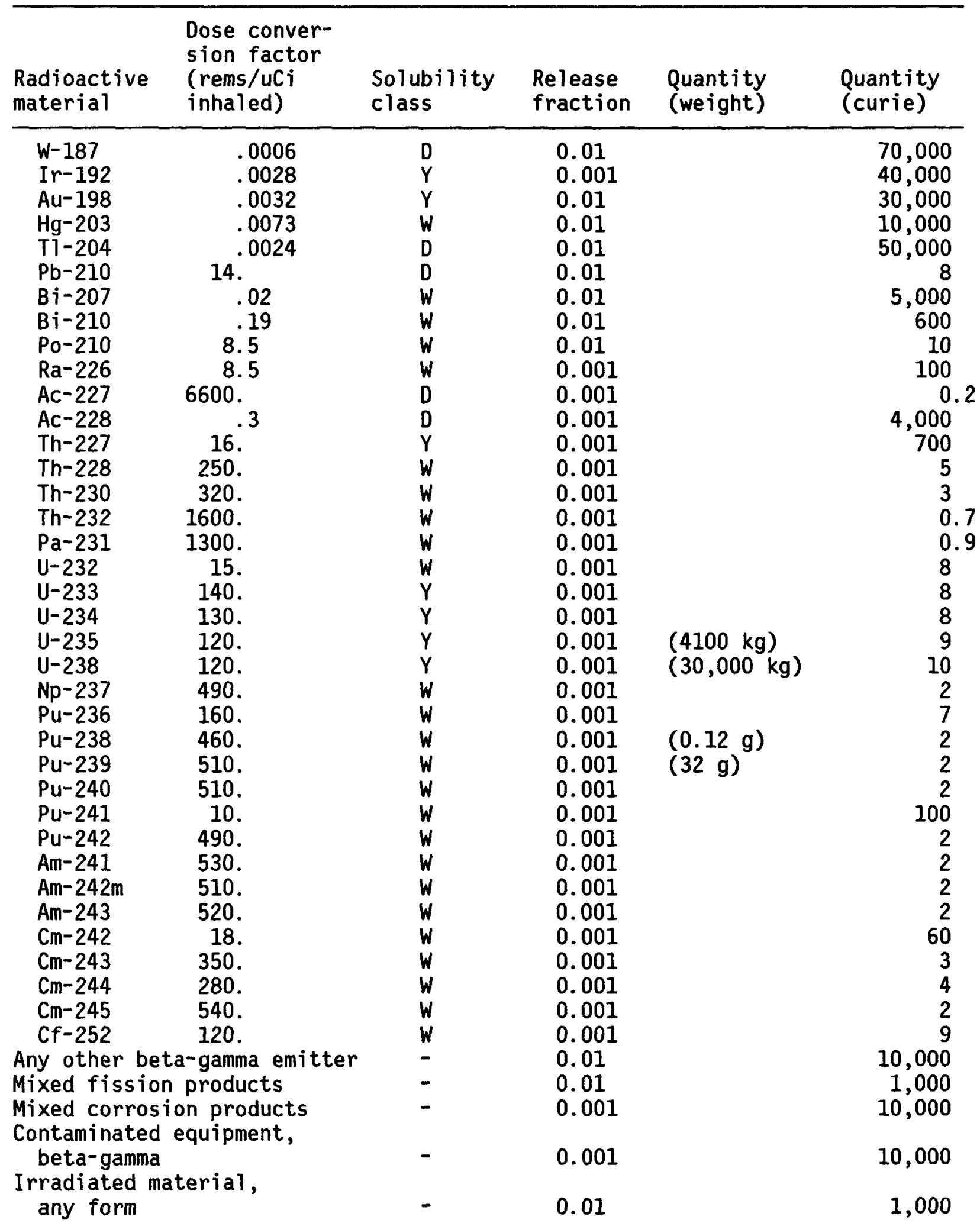


Table 13. (continued)

\begin{tabular}{llllr}
\hline \multicolumn{1}{c}{$\begin{array}{l}\text { Dose conver- } \\
\text { sion factor } \\
\text { (rems/uCi } \\
\text { inhaled) }\end{array}$} & $\begin{array}{l}\text { Solubility } \\
\text { class }\end{array}$ & $\begin{array}{l}\text { Release } \\
\text { fraction }\end{array}$ & $\begin{array}{l}\text { Quantity } \\
\text { (weight) }\end{array}$ & $\begin{array}{c}\text { Quantity } \\
\text { (curie) }\end{array}$ \\
\hline $\begin{array}{l}\text { Irradiated material-solid, } \\
\text { noncombustible }\end{array}$ & - & 0.001 & 10,000 \\
$\begin{array}{l}\text { Mixed radioactive waste, } \\
\text { beta gamma except }\end{array}$ & - & 0.01 & 1,000 \\
$\begin{array}{l}\text { I-125 and I-131 } \\
\begin{array}{l}\text { Packaged waste, } \\
\text { beta gamma* }\end{array}\end{array}$ & - & 0.001 & 10,000 \\
$\begin{array}{l}\text { Any other alpha emitter } \\
\text { Contaminated equipment, } \\
\text { alpha }\end{array}$ & - & 0.001 & 20 \\
$\begin{array}{l}\text { Packaged waste, } \\
\text { alpha }\end{array}$ & - & 0.0001 & 20 \\
$\begin{array}{l}\text { *Type B packages assumed to have no release and no need for emergency } \\
\text { preparedness. }\end{array}$ & - & & \\
\end{tabular}

where $Q_{i}=$ the quantity of material $i$, curies

$$
\begin{aligned}
& \mathrm{RF}_{i}= \text { release fraction of material } i . \text { (Release fractions are for a } \\
& \text { severe facility fire, which has been identified as the accident } \\
& \text { with the largest plausible release fractions.) } \\
& H_{I i}= \text { the effective dose equivalent from material } i \text { for the inhalation } \\
& \text { pathway, rems/curie released. } \\
& H_{G C i}= \text { the effective dose equivalent from material } i \text { for the ground } \\
& \text { contamination pathway, rems/curie released. } \\
& H_{C S i}= \text { the effective dose equivalent from material } i \text { for the cloudshine } \\
& \text { pathway, rems/curie released. }
\end{aligned}
$$

For all materials of greatest interest for fuel cycle and other radioactive material licensees, the dose from the inhalation pathway $\mathrm{H}_{\mathrm{I} i}$ will dominate the dose. 
$\mathrm{H}_{\mathrm{Ii}}$ was calculated by assuming a maximum plausible intercept fraction for non-depositing (non-particulate) materials of $10^{-6}$. Thus,

$$
H_{I i}=10^{-6} \times D C F
$$

where $D C F=$ dose conversion factor, rems/curie inhaled. This intercept fraction was found to be the intercept fraction that would be calculated a Gaussian plume dispersion model, a distance of 100 meters on the plume centerline, atmospheric stability class $F, 1 \mathrm{~m} / \mathrm{s}$ wind speed, release duration of 30 minutes, building size of $10 \mathrm{~m}$ by $25 \mathrm{~m}$, no other obstructions to spread the plume, and no plume rise due to buoyancy.

According to this model intercept fractions would exceed $10^{-6}$ at distances closer than 100 meters from the release point. Such larger intercept fractions are not used because they are not considered physically realistic. Larger intercept fractions require the assumption that the smoke from a fire will not rise over the heads of people closer than 100 meters and that the people would stand in dense smoke for the full duration of the release. These assumptions are not considered realistic.

Next, a deposition model was added to the meteorological model described above. A deposition velocity of $1 \mathrm{~cm} / \mathrm{sec}$ was assumed. This reduces the intercept fraction at 100 meters to $0.9 \times 10^{-6}$, but adds a dose contribution from ground shine. Exposure to ground shine for 8 hours was assumed.

Table 13 includes all radionuclides listed on 20 or more of NRC's approximately 9,000 licenses. A quantity for I-129 is not included because saturation would prevent the thyroid from absorbing enough I-129 to reach the 5-rem protective action guide dose. Table 13 also includes all beta-gamma emitters listed on more than one but less than 20 licenses if the quantity that might deliver an effective dose equivalent exceeding 1 rem is less than 10,000 curies. Table 13 also includes all alpha emitters listed on more than one but less than 20 licenses if the quantity that might deliver an effective dose equivalent exceeding 1 rem is less than 2 curies.

The quantities in Table 13 are different from quantities previously published in NUREG-0767, "Criteria for Selection of Fuel Cycle and Major Materials Licensees Needing Radiological Contingency Plans," and Federal Register Notices with orders (46 FR 12566) and an Advance Notice of Rulemaking (46 FR 29712). The main reasons are: (1) dosimetric models from ICRP Publications 26 and 30 have been used instead of the older models from ICRP Publication 2 and 
(2) release fractions have changed as a result of further study. Meteorological models are slightly different, but this has a small effect in most cases. The intercept fraction for inhalation of a material that does not deposit on the ground is 10-6 in both cases. For particulates, which do deposit on the ground, the dose per curie released can be as much as $11 \%$ lower for radionuclides with negligible external dose to about 5 times higher for radionuclides whose major dose pathway is groundshine from material deposited on the ground.* The values in Table 13 include consideration of groundshine.

Quantities are also given for certain frequently occurring mixtures of radionuclides.

Mixed fission products are assigned the generally applicable release fraction of 0.01 and a quantity of 1000 curies. This value is typical for fission products, assumes that short-lived iodines will not be present, and assumes that no single nuclide will account for more than perhaps 5 to $10 \%$ of the activity. In particular, $\mathrm{Sr}-90$ is likely to be the dominant contributor to dose and is assumed to be no more than 5 to $10 \%$ of the activity.

Mixed corrosion products are assumed to be bound to surfaces and thus assigned the smaller release fraction of 0.001 . Cobalt-60 is likely to be the dominant nuclide. The quantity assigned is 10,000 curies.

Contaminated equipment, beta-gamma is likewise assumed to have a lower release fraction of 0.001 due to bonding to surfaces. The activity assigned is 10,000 curies. Sr-90 is assumed to be less than $10 \%$ of the activity.

Irradiated material is assigned the same values as mixed fission products because the forms and nuclides are likely to be similar. However, solid noncombustible irradiated material is assigned a lower release fraction of 0.001 and an activity of 10,000 curies.

Mixed radioactive waste, beta-gamma, except I-131 and I-125 is assigned an activity of 1000 curies. Iodine-131 and iodine-125 are assumed not to dominate the hazard due to their short half-lives. If significant quantities of iodine would be in the waste, their quantities should be calculated separately.

Packaged waste, beta-gamma is assumed to have one-tenth the release fraction of unpackaged material due to an assumed protection provided by the packaging. The quantity assigned is 10,000 curies.

*See Table 5.5 of NUREG/CR-3657 for contributions of each pathway. 
Contaminated equipment, alpha is assumed to have one-tenth the release fraction of alpha emitters in general due to bonding onto surfaces. An activity is 20 curies is assigned.

Packaged waste, alpha is assigned an activity of 20 curies because the packages are assumed to provide some protection against release.

Type B packaged waste is assumed to have no significant release because Type $B$ packages are constructed and tested to survive various types of severe accidents including fires.

\subsubsection{Radiopharmaceutical Manufacturing}

These plants produce radionuclide-labeled compounds for medical diagnosis and treatment. Some handle only one or two radionuclides, while others handle many. The radionuclides of most significance are: $\mathrm{H}-3, \mathrm{C}-14, \mathrm{P}-32, \mathrm{~S}-35$, Sr-90, Mo-99, I-125, I-131, and Cs-137.

\subsubsection{Accident History}

of the accidents listed in Tables 11 and 12, two were at radiopharmaceutical manufacturing plants. Those are the 1980 inplant contamination with Am-241 and the 1981 release of 3.2 curies of sulfur-35. Both occurred at New England Nuclear in N. Billerica, Mass. Doses offsite in both cases would be well below EPA's protective action guides.

\subsubsection{Accident Source Terms}

Sutter analyzed potential accidents at radiopharmaceutical manufacturing facilities, including loading dock fires, major facility fires, tornadoes, earthquakes, spills and leaks, explosions, cyclotron accidents, and fires in waste storage areas.

Fires were seen to have the largest potential releases, and in particular a major facility fire involving all the radioactive material in a building was seen theoretically to yield the largest potential release. Release fractions for radioactive materials are based on the assumption that almost all the licensed material is involved in the fire, that storage containers (except sealed sources) are ineffective in protecting the material and limiting releases, 
and that the fire burns long and intensely. For these conditions to be met it is likely that the building containing the material would be woodframe or some other combustible material, that no automatic sprinkler system or other fire prevention system would operate, and that the local fire department would be ineffective in fighting the fire. The entire building and its contents are assumed to be consumed in the fire. Table 14 lists the maximum quantity authorized for possession by any licensee and the release fraction for each radionuclide involved in a major facility fire.

Table 14. Radiopharmaceutical Manufacturing: Maximum Possession Limits, Release Fractions, and Doses Due to a Major Facility Fire

\begin{tabular}{|c|c|c|c|c|}
\hline $\begin{array}{l}\text { Radioactive } \\
\text { material }\end{array}$ & $\begin{array}{l}\text { Maximum } \\
\text { licensed } \\
\text { possession } \\
\text { limit (Ci) }\end{array}$ & Licensee & $\begin{array}{l}\text { Release } \\
\text { fraction }\end{array}$ & $\begin{array}{l}\text { Effective dose } \\
\text { equivalent, rem }\end{array}$ \\
\hline $\begin{array}{l}\mathrm{H}-3 \\
\mathrm{C}-14 \\
\mathrm{P}-32 \\
\mathrm{~S}-35 \\
\mathrm{Ca}-45 \\
\mathrm{Cr}-51 \\
\mathrm{Fe}-55 \\
\mathrm{Ni}-63 \\
\mathrm{Se}-75 \\
\mathrm{Kr}-85 \\
\mathrm{Rb}-86 \\
\mathrm{~S} r-90 \\
\mathrm{Mo}-99 \\
\mathrm{Ru}-103 \\
\mathrm{Sn}-113 \\
\mathrm{I}-125 \\
\mathrm{I}-131 \\
\mathrm{Xe}-133 \\
\mathrm{Cs}-134 \\
\mathrm{Cs}-137 \\
\mathrm{Ce}-141 \\
\mathrm{Yb}-169 \\
\mathrm{Tm}-170 \\
\mathrm{Au}-198\end{array}$ & $\begin{array}{r}150,000 \\
500 \\
500 \\
1,000 \\
50 \\
100 \\
200 \\
1,000 \\
100 \\
10,000 \\
50 \\
500 \\
2,000 \\
25 \\
100 \\
100 \\
500 \\
1,000 \\
25 \\
500 \\
50 \\
50 \\
25 \\
200\end{array}$ & $\begin{array}{l}\text { NEN* } \\
\text { NEN-Boston } \\
\text { NEN } \\
\text { NEN } \\
\text { NEN } \\
\text { NEN } \\
\text { NEN } \\
\text { NEN } \\
\text { NEN } \\
\text { NEN } \\
\text { NEN } \\
\text { NEN } \\
\text { NEN/Squibb } \\
\text { NEN } \\
\text { NEN } \\
\text { NEN/Mal linckrodt } \\
\text { Mal linckrodt } \\
\text { NEN } \\
\text { NEN } \\
\text { NEN } \\
\text { NEN } \\
\text { NEN } \\
\text { NEN } \\
\text { NEN }\end{array}$ & $\begin{array}{l}0.5 \\
0.01 * * * \\
0.5 \\
0.5 \\
0.01 \\
0.01 \\
0.01 \\
0.01 \\
0.01 \\
1.0 \\
0.01 \\
0.01 \\
0.01 \\
0.01 \\
0.01 \\
0.5 \\
0.5 \\
1.0 \\
0.01 \\
0.01 \\
0.01 \\
0.01 \\
0.01 \\
0.01\end{array}$ & $\begin{array}{l}0.1 \text { to } 10 . \\
0 \text { to } 0.01 \\
0.04 \text { to } 4 . \\
0.01 \text { to } 1 . \\
0 \text { to } 0.003 \\
0 \text { to } 0.005 \\
0 \text { to } \\
0.001 \text { to } 0.06 \\
0 \text { to } 0.008 \\
0 \text { to } 0.002 \\
0 \text { to } 0.003 \\
0.05 \text { to } 5 . \\
0.001 \text { to } 0.08 \\
0 \text { to } 0.002 \\
0 \text { to } 0.01 \\
0.3 \text { to } 30 . \text { (child's thyroid) } \\
5 \text { to } 500 . \text { (child's thyroid) } \\
0 \text { to } 0.001 \\
0 \text { to } 0.01 \\
0.002 \text { to } 0.2 \\
0 \text { to } 0.004 \\
0 \text { to } 0.004 \\
0 \text { to } 0.006 \\
0 \text { to } 0.008\end{array}$ \\
\hline
\end{tabular}

\footnotetext{
*NEN = New England Nuclear, North Billerica, Mass.

**zero in the dose column indicates a dose of less than one millirem. ***Non-carbon dioxide release fraction.
} 


\subsubsection{Calculations of Doses}

A range of doses due to release of radionuclides in a major facility fire was calculated to reflect uncertainty in the doses calculated. The upper end of the range represents the worst-case conditions - maximum release fractions, $\mathrm{F}, 1 \mathrm{~m} / \mathrm{s}$ weather, and no plume buoyancy. From Figure 1 it can be seen that more typical weather $(D, 4.5 \mathrm{~m} / \mathrm{s})$ reduces doses by a factor of almost 8 , that assuming buoyancy during $F, 1 \mathrm{~m} / \mathrm{s}$ weather reduces doses by a factor of 37 , and that assuming both $D, 4.5 \mathrm{~m} / \mathrm{s}$ weather and buoyancy reduces doses by a factor of 68 . Furthermore releases may be smaller than assumed because of many possible mitigating factors.

We therefore present in Table 14 a range of doses to reflect these uncertainties. The upper end of the range is the worst-case described above and the lower end of the range is that value divided by 100 . The range is considered likely to encompass the dose likely to be received by a person on the plume centerline due to a severe accident.

From Table 14 it can be seen that in only one case is the potential dose significantly larger than the upper end of the EPA's protective action guide range - I-131 at Mallinckrodt.

\subsubsection{Implications for Emergency Preparedness}

The radioactive materials possessed by radiopharmaceutical manufacturers might present a potential hazard from H-3, P-32, S-35, Sr-90, I-125, and I-131. I-131 exceeds the EPA's protective action guides by the largest margin with a dose of 5 to 500 rems to a child's thyroid within $100 \mathrm{~m}$ and 0.2 to 20 rems at $1000 \mathrm{~m}$. All other materials would drop below the lower end of the protective action guide range within 350 to $400 \mathrm{~m}$.

\subsubsection{Radiopharmacies and Hospitals}

Radiopharmacies act as receivers and distributors of radiopharmaceuticals for use by hospitals and medical research facilities. They are not production facilities, and thus minimal handling of radioactive materials takes place. In general, either a hospital will have its own radiopharmacy, or, as is currently taking place in the industry, a large metropolitan area will have one or more 
private radiopharmacy firms serving as central distribution points for the hospitals and research facilities in the area.

A radiopharmacy receives shipments of radiopharmaceuticals from vendors either as bulk quantities or as prepackaged diagnostic kits. With prepackaged kits, the pharmacy merely holds the material until it is required for use by the hospital. For bulk quantities, the primary bulk material consists of Mo-99/Tc-99m generators. The radiopharmacy prepares individual doses by pipetting dose size aliquots into a syringe, which is then transported to its final destination. This loading of Tc-99m is usually conducted in a fume hood. If other bulk materials are handled, such as iodine-labeled compounds, they may be dispensed in glove boxes.

\subsubsection{Accident History}

There are no known accidents at radiopharmacies or hospitals with any offsite significance. The events that have been reported are small spills in the laboratory that were cleaned up in a routine manner or surface contamination on packages.

\subsubsection{Accident Source Terms}

Sutter considered several classes of accidents and concluded that a major facility fire would result in the largest releases. The fire is assumed to consume the entire building and the roof is assumed to be breached providing a direct path to the atmosphere for airborne contamination.

Table 15 lists the maximum quantity licensed for possession by any licensee and release fractions for a major facility fire.

\subsubsection{Calculations of Doses}

Doses for a major fire at a radiopharmacy or hospital are shown in Table 15. Doses from all radionuclides are far below the EPA's protective action guides. A zero for the effective dose equivalent indicates that dose is less than 1 millirem. 
Table 15. Radiopharmacy: Maximum Possession Limits, Release Fractions, and Doses Due to a Major Facility Fire

\begin{tabular}{|c|c|c|c|c|}
\hline $\begin{array}{l}\text { Radioactive } \\
\text { material }\end{array}$ & $\begin{array}{l}\text { Maximum licensed } \\
\text { possession } \\
\text { limit ( } \mathrm{C} \text { ) }\end{array}$ & $\begin{array}{l}\text { Chemical } \\
\text { forms }\end{array}$ & $\begin{array}{l}\text { Release } \\
\text { fraction }\end{array}$ & $\begin{array}{l}\text { Dose } \\
\text { equivalent, } \\
\text { rem }\end{array}$ \\
\hline $\mathrm{H}-3$ & $0.05 \mathrm{Ci}$ & In vitro test kits & 0.5 & 0 \\
\hline$C-14$ & 0.05 & In vitro test kits & $0.01^{*}$ & 0 \\
\hline $\mathrm{Cr}-51$ & 0.15 & $\begin{array}{l}\text { Labeled serum, } \\
\text { sodium chromate }\end{array}$ & 0.01 & 0 \\
\hline Co-58 & 0.15 & $\begin{array}{l}\text { Cyanocobalamin } \\
\text { (vitamin Bl2) }\end{array}$ & 0.001 & 0 \\
\hline $\mathrm{Fe}-59$ & 0.15 & $\begin{array}{l}\text { Chloride, citrate, } \\
\text { sulfate }\end{array}$ & 0.01 & 0 \\
\hline $\mathrm{Se}-75$ & 0.1 & Labeled compound & 0.01 & 0 \\
\hline$S r-90$ & 0.5 & Nitrate, chloride & 0.01 & 0 to 0.006 \\
\hline Mo-99/Tc-99m & 75 . & $\begin{array}{l}\text { Mo-99/Tc- } 99 \mathrm{~m} \\
\text { generators (1 iquid) }\end{array}$ & 0.01 & 0 to 0.004 \\
\hline$I-125$ & 0.15 & $\begin{array}{l}\text { Na I, fibrogen, } \\
\text { diagnostic kits }\end{array}$ & 0.5 & $\begin{array}{l}0.001 \text { to } \\
0.1 \text { (child's } \\
\text { thyroid) }\end{array}$ \\
\hline$I-131$ & 0.75 & $\begin{array}{l}\mathrm{Na} \mathrm{I}, \text { labeled } \\
\text { organic compounds }\end{array}$ & 0.5 & $\begin{array}{l}0.007 \text { to } \\
0.7 \text { (child's } \\
\text { thyroid) }\end{array}$ \\
\hline$X e-133$ & 1. & Gas or saline & 1.0 & 0 \\
\hline
\end{tabular}

Note: sealed sources are not included.

Reference: Sutter report.

*Non-carbon dioxide release fraction.

\subsubsection{Implications for Emergency Preparedness}

No offsite radiological emergency preparedness is needed for radiopharmacies and hospitals because doses outside the buildings are far below the 1-rem lower limit protective action guide.

\subsubsection{Sealed Source Manufacturing}

Sealed source manufacturers produce encapsulate radioactive materials into sources of alpha, beta, or gamma radiation or self-luminous devices for use in watches, compasses, and aircraft instrumentation. 
Means of producing sealed sources vary, but in general consist of receiving the bulk radioactive material in a shipping container, dispensing the material in an appropriate containment in the required amounts, and placing the material in a capsule which is welded or brazed. Thus, little actual chemical processing occurs; rather, the operations are more of a redistribution and repackaging process. In some cases the radioactive material is put through a series of steps to convert it to microspheres prior to encapsulation, and this operation does involve some chemical processing. The production of tritium light source usually requires that the gaseous tritium be transferred to a glass ampule, although in some cases a tritiated paint is produced for application to watch or compass dials.

The majority of the time, the radioactive materials are in a form not readily airborne. These could be pellets, metallic wafers or foils, platinum gauzes, etc. Plastic microspheres of controlled particle size encase some isotopes. These are generally spherical, 10 to 250 microns in diameter.

\subsubsection{Accident History}

Several of the accidents 1 isted in Tables 11 and 12 are relevant to sealed source manufacturing. They are: the 1959 drybox explosion involving Po-210 at Mound Laboratory, the 1960 processing cave fire involving curium at the University of California-Berkeley, the 1967 cutting of an Ir-192 pellet in a hot cell at Babcock and Wilcox, the 1981 escape of Ir-192 from a hot cell at Tech/Ops, the 1983 accidental cutting open of an Am-241 sealed source at Gulf Nuclear, and the 1983 accidental cutting open of a Cs-137 sealed source at Shelwell Services, Inc. None of these accidents involved a large proportion of the radioactive material at the facility. All except the Gulf Nuclear and Shelwell Services accidents involved filtered hot cells. In all cases the airborne release to the environment was small.

\subsubsection{Accident Source Terms}

Sutter analyzed a number of types of accidents including glove box or hot cell fires, container or piping leaks, spills, explosions, tornadoes, and major facility fires burning down the entire building. The major facility fire produced by far the largest releases. 
Table 16 lists the maximum licensed possession limits for any licensee and release fractions for each radionuclide. The release fractions shown in Table 16 can be assumed for an intense fire of 30 minutes duration in which the building is breached.

\subsubsection{Calculations of Doses}

As discussed previously a range of doses is presented in Table 16 due to a major facility fire. The highest doses represent a conservative worst case. The lower end of the dose range (a factor of 100 lower) represent a severe but not worst-case accident during typical meteorology with some consideration given to plume buoyancy. It is clear that a few radionuclides are of significant concern: Po-210, plutonium, Am-241, and $\mathrm{Cm}-244$. Doses exceeding the upper end of the protective action guide range seem plausible. All of these are alpha emitters for which inhalation is the exposure pathway. Tritium, strontium-90, I-125, Cs-137, Tm-170, Cm-242 and $\mathrm{Cm}-243$ might also be able to exceed the lower end of the protective action guide range.

\subsubsection{Implications for Emergency Preparedness}

Emergency preparedness should be considered for certain sealed source manufacturing facilities handling large quantities of materials. Those facilities potentially exceeding 1 rem are: 3M, Monsanto, Tech/Ops, and Safety Light.

In addition, it may be possible for effective dose equivalents to exceed the protective action guide value of 5 rems at distances as great as $1000 \mathrm{~m}$. This could potentially occur for Po-210 at 3M and plutonium, Am-241, and Cm-244 at Monsanto. It is possible that these two plants would need more emergency preparedness than the others.

\subsubsection{University Research Laboratories}

At university research laboratories, radioactive materials are received generally from radiopharmaceutical manufacturers and used in many laboratories covered under one license. They are received at and distributed from a central 
Table 16. Sealed Source Manufacturing: Maximum Possession Limits, Release Fractions, and Doses Due to a Major Facility Fire

\begin{tabular}{|c|c|c|c|c|c|}
\hline $\begin{array}{l}\text { Radioactive } \\
\text { material }\end{array}$ & $\begin{array}{l}\text { Maximum } \\
\text { licensed } \\
\text { posession } \\
\text { limit (Ci) }\end{array}$ & Form & Licensee & $\begin{array}{l}\text { Release } \\
\text { fraction }\end{array}$ & $\begin{array}{l}\text { Effective } \\
\text { dose } \\
\text { equivalent, } \\
\text { rems }\end{array}$ \\
\hline $\mathrm{H}-3$ & $100,000 \mathrm{Ci}$ & volatile & Safety Light & 0.5 & 0.06 to 6.5 \\
\hline$c-14$ & 50 & & Amersham & $0.01^{*}$ & 0 to 0.001 \\
\hline $\mathrm{Co}-60$ & 20,000 & $\begin{array}{l}75 \% \text { metallic } \\
\text { pellets } \\
25 \% \text { sealed } \\
\text { sources }\end{array}$ & $\begin{array}{l}\text { Automation } \\
\text { Ind. }\end{array}$ & 0.0001 & $\begin{array}{l}0.004 \text { to } \\
0.4\end{array}$ \\
\hline $\mathrm{Kr}-85$ & 1,500 & noble gas & $3 M$ & 1.0 & 0 \\
\hline$S r-90$ & 3,000 & $\begin{array}{l}1000 \mathrm{Ci} \text { in } \\
\text { solution in } \\
0.1 \mathrm{iter} \text { of } \\
0.1 \mathrm{~N} \mathrm{HCl} \\
\text { also, sealed } \\
\text { sources }\end{array}$ & $3 M$ & 0.01 & 0.3 to 33 \\
\hline $\mathrm{Sb}-124$ & 50 & & Monsanto & 0.01 & 0 to 0.01 \\
\hline$I-125$ & 100 & $\begin{array}{l}5 \mathrm{Ci} \text { in } \mathrm{KOH} \\
1 \text { iquid } \\
5 \mathrm{Ci} \text { on resin } \\
\text { beads }\end{array}$ & $3 M$ & 0.5 & $\begin{array}{l}0.7 \text { to } 70 . \\
\text { (child's } \\
\text { thyroid) }\end{array}$ \\
\hline$C s-137$ & 10,000 & & Tech/Ops & 0.01 & 0.03 to 3 \\
\hline$P_{m-147}$ & 3,500 & $\begin{array}{l}800 \mathrm{Ci} \text { in } \\
\text { solution in } \\
0.1 \mathrm{liter} \text { of } \\
0.1 \mathrm{~N} \mathrm{HCl} \\
\text { also, sealed } \\
\text { sources }\end{array}$ & $3 M$ & 0.01 & $\begin{array}{l}0.008 \text { to } \\
0.8\end{array}$ \\
\hline$Y b-169$ & 100 & $\begin{array}{l}5 \mathrm{Ci} \text { liquid } \\
\mathrm{Yb} \text { chelate }\end{array}$ & $3 M$ & 0.5 & $\begin{array}{l}0.004 \text { to } \\
0.4\end{array}$ \\
\hline $\mathrm{Tm}-170$ & 5,000 & & Tech/Ops & 0.01 & 0.01 to 1 \\
\hline $\mathrm{Ta}-182$ & 200 & $\begin{array}{l}\text { metallic or } \\
\text { carbide }\end{array}$ & Tech/Ops & 0.01 & 0 to 0.001 \\
\hline $\mathrm{Ta}-183$ & 2,000 & $\begin{array}{l}\text { metallic or } \\
\text { carbide }\end{array}$ & Tech/Ops & 0.01 & 0 to 0.001 \\
\hline I $r-192$ & 50,000 & $\begin{array}{l}\text { solid metal } \\
\text { or sealed } \\
\text { source }\end{array}$ & Tech/Ops & 0.0001 & $\begin{array}{l}0.001 \text { to } \\
0.1\end{array}$ \\
\hline$T 1-204$ & 50 & & Monsanto & 0.01 & 0 to 0.001 \\
\hline
\end{tabular}

*Non-carbon dioxide release fraction. 
Table 16. (continued)

\begin{tabular}{|c|c|c|c|c|c|}
\hline $\begin{array}{l}\text { Radioactive } \\
\text { material }\end{array}$ & $\begin{array}{l}\text { Maximum } \\
\text { licensed } \\
\text { posession } \\
\text { limit (Ci) }\end{array}$ & Form & Licensee & $\begin{array}{l}\text { Release } \\
\text { fraction }\end{array}$ & $\begin{array}{l}\text { Effective } \\
\text { dose } \\
\text { equivalent, } \\
\text { rems }\end{array}$ \\
\hline $\mathrm{Bi}-210$ & 200 & metal slugs & $3 M$ & 0.001 & 0 to 0.03 \\
\hline Po- 210 & 4,000 & $\begin{array}{l}\text { up to } 1500 \mathrm{Ci} \\
\text { in } 401 \text { iters } \\
\text { of } 2 \mathrm{M} \mathrm{HNO}_{3} ; \\
\text { up to } 2500 \mathrm{Ci} \\
\text { in waste } \\
\text { primarily as } \\
\text { microspheres }\end{array}$ & $3 M$ & $\begin{array}{l}0.01 \\
0.001\end{array}$ & $\begin{array}{l}\text { 1. to } 100 . \\
\text { (per } \\
1500 \mathrm{Ci}) \\
0.2 \text { to } 20 . \\
(\text { per } \\
2500 \mathrm{Ci})\end{array}$ \\
\hline $\mathrm{Np}-237$ & 0.1 & & Monsanto & 0.001 & 0 to 0.04 \\
\hline $\begin{array}{c}\mathrm{Pu}-238,236 \\
239,240 \\
241,242\end{array}$ & $199 \mathrm{~g}$ & $\begin{array}{l}250 \mathrm{Ci} \text { as } \\
\text { unsealed } \\
\text { powder oxide }\end{array}$ & Monsanto & 0.001 & $\begin{array}{l}0.75 \text { to } 75 . \\
\text { (per } \\
250 \mathrm{Ci})\end{array}$ \\
\hline$A m-241$ & 6,000 & $\begin{array}{l}250 \mathrm{Ci} \text { as } \\
\text { unsealed } \\
\text { powder oxide; } \\
\text { remainer as } \\
\text { sealed } \\
\text { sources }\end{array}$ & Monsanto & 0.001 & $\begin{array}{l}1.2 \text { to } 120 . \\
\text { (per } \\
250 \mathrm{Ci})\end{array}$ \\
\hline $\mathrm{Cm}-242$ & 600 & & Monsanto & 0.001 & 0.1 to 10 \\
\hline $\mathrm{Cm}-243$ & 10 & & Monsanto & 0.001 & 0.03 to 3.0 \\
\hline $\mathrm{Cm}-244$ & 600 & & Monsanto & 0.001 & 1.5 to 150. \\
\hline$c f-252$ & $10 \mathrm{mg}$ & solid pellet & Monsanto & 0.001 & $\begin{array}{l}0.006 \text { to } \\
0.6\end{array}$ \\
\hline
\end{tabular}

receiving area. Solid waste is usally stored at a central location prior to disposal. Thus, the central receiving and waste storage areas have the largest radioactive material inventories. License limits are low, and actual inventories are usually fractions of the limit.

The laboratories are scattered in different locations on a campus; up to 500 locations can handle radioactive materials at a single licensed facility. Several laboratories may be located in one building. The generally low quantities of material licensed and the diffuse operations reduces the risks associated with these facilities. 


\subsubsection{Accident History}

There have been no accidents at facilities of this type with significance for offsite protective actions. Releases have generally been very small.

\subsubsection{Accident Source Terms}

The accidents considered by Sutter are spills and leaks, tornadoes, explosions, fires, waste incinerator error, and patient related accidents. Again, fires are seen to yield the greatest releases. However a major facility fire involving the entire inventory is not reasonable because of the diffuseness of the operations. The fire with the maximum potential release is seen as being a major fire at the shipping and receiving department of the University. Sutter concluded on the basis of information submitted to NRC by licensees that, at most, $10 \%$ of the authorized possession limits would be involved. Table 17 lists the maximum possession limits for any licensee and the release fractions for a major fire at the shipping and receiving area.

Table 17. University Research Laboratories: Maximum Possession Limits Release Fractions, and Doses Due to a Major Fire

\begin{tabular}{lccl}
\hline $\begin{array}{l}\text { Radioactive } \\
\text { material }\end{array}$ & $\begin{array}{l}\text { Maximum licensed } \\
\text { possession limit (Ci) }\end{array}$ & $\begin{array}{l}\text { Release } \\
\text { fraction }\end{array}$ & $\begin{array}{l}\text { Effective dose } \\
\text { equivalent, rems }\end{array}$ \\
\hline $\mathrm{H}-3$ & 3000 & 0.5 & 0.002 to 0.2 \\
$\mathrm{C}-14$ & 10 & $0.01^{\star}$ & 0 \\
$\mathrm{P}-32$ & 5 & 0.5 & 0 to 0.04 \\
$\mathrm{~S}-35$ & 5 & 0.5 & 0 to 0.01 \\
$\mathrm{Ni}-63$ & 1 & 0.01 & 0 \\
$\mathrm{Sr}-90$ & 0.5 & 0.01 & 0 to 0.005 \\
$\mathrm{Mo}-99 / \mathrm{Tc}-99 \mathrm{~m}$ & 10 & 0.01 & 0 \\
$\mathrm{I}-125$ & 8 & 0.5 & 0.06 to 5.5 (child's thyroid) \\
$\mathrm{I}-131$ & 1 & 0.5 & 0.01 to 1. (child's thyroid) \\
$\mathrm{Xe}-133$ & 10 & 1.01 & 0.009 to 0.9 \\
Po-210 & 10 & 0.001 & 0.003 to 0.3 \\
Am-241 & 0.5 & 0.001 & 0.003 to 0.3 \\
$\mathrm{Cm}-244$ & 1 & 0.001 & 0 to 0.01 \\
$\mathrm{Cf}-252$ & 0.1 & & \\
\hline
\end{tabular}

*Non-carbon dioxide release fraction. 


\subsubsection{Calculations of Doses}

A range of calculated effective dose equivalents is shown in Table 17. The largest potential doses are from I-125, Po-210, and Am-241. The range reflects the likelihood that release fractions will be considerably below those shown in the table and a range of possible meteorology.

\subsubsection{Implications for Emergency Preparedness}

Offsite emergency preparedness does not appear necessary for university research laboratories because potential effective dose equivalents are low.

\subsubsection{Waste Warehousing and Burial}

In waste warehousing, radioactive material in containers (drums) is stored for a period of generally not more than six months. Drums may be opened in the waste warehousing operation. They are stored and then transported to a licensed waste burial ground.

\subsubsection{Accident History}

Accidents involving waste warehousing and burial have been minor, such as very small releases, leaking containers, and containers having surface contamination above regulatory limits. There have been no offsite airborne releases of significance.

\subsubsection{Accident Source Terms}

Warehousing. Since most radioactive waste is in metal drums, the potential for accidental releases is low. An event of significant magnitude to breach the drums would be required to make material airborne. Accidents considered are tornadoes, earthquakes, fires, and explosions.

A major facility fire is seen as yielding the largest releases. The activities of radioactive materials becoming airborne were estimated by Sutter. These activities are listed in Table 18. 
Table 18. Waste Warehousing Airborne Releases and Doses Due to a Major Facility Fire

\begin{tabular}{lcll}
\hline $\begin{array}{l}\text { Radioactive } \\
\text { material }\end{array}$ & $\begin{array}{l}\text { Quantity } \\
\text { present (Ci) }\end{array}$ & $\begin{array}{l}\text { Release } \\
\text { fraction }\end{array}$ & $\begin{array}{l}\text { Effective dose } \\
\text { equivalent, rem }\end{array}$ \\
\hline $\mathrm{H}-3$ & 6200 & 0.5 & 0.004 to 0.4 \\
$\mathrm{C}-14$ & 160 & $0.01^{*}$ & 0 to 0.004 \\
$\mathrm{P}-32$ & 160 & 0.5 & 0.01 to 1. \\
$\mathrm{~S}-35$ & 120 & 0.5 & 0.002 to 0.2 \\
$\mathrm{Cr}-51$ & 60 & 0.01 & 0 to 400 (child's thyroid) \\
$\mathrm{I}-125$ & 280 & 0.5 & 4 to \\
$\mathrm{I}-131$ & 20 & 0.5 & 0.4 to 40 . (child's thyroid)
\end{tabular}

*Non-carbon dioxide release fraction.

Burial. Accidents during waste burial were analyzed in a draft environmental impact statement.* A major trench fire of two hours duration was determined to be the accident with the largest potential airborne release. Dropped and ruptured containers were determined to cause smaller releases. The reader is referred to the referenced environmental statement for the details of the assumed releases.

\subsubsection{Calculations of Doses}

Warehousing. A range of effective dose equivalents outside the building due to a major warehouse fire are also shown in Table 18 . The range represents the uncertainty in doses that might result from a severe accident.

Burial. Doses calculated for a major trench fire are given in NUREG-0782 as 0.006 rem whole body and 0.03 rem to the lungs. While these doses were not calculated by exactly the same calculational techniques as others in this report, they are so low that there seems to be no need to recalculate them.

*0ffice of Nuclear Material Safety and Safeguards, Draft Environmental Impact Statement on 10 CFR Part 61 "Licensing Requirements for Land Disposal of Radioactive Waste," NRC Report NUREG-0782, Volume 2, Section 6.2.2, 1981. 


\subsubsection{Implications for Emergency Preparedness}

Since potential accident doses for waste burial are far below the EPA's protective action guides, burial does not seem to require special offsite emergency preparedness. For warehousing, the radioiodines I-125 and I-131 may make some special emergency preparedness appropriate.

\subsubsection{Depleted Uranium Products*}

Depleted uranium is used to make a number of products: radiation shields for radioisotopes and $x$-ray machines, aircraft counterweights, armor-piercing bullets, and artillery shells. Among the processing operations performed are: reduction of "green salt" (uranium tetrafluoride) to metal; melting and casting of the metal; welding; extrusion, cutting and etching; and machining. Since uranium metal turnings and powders will burn, fires are a potential accident of concern.

\subsubsection{Accident History}

Table 6 listed fires and explosions involving uranium and is relevant to fabrication of depleted uranium products. The releases and offsite contamination that resulted were negligible in all cases.

\subsubsection{Accident Source Terms}

Three potential scenarios during three operations suggest themselves as potentially resulting in the largest airborne releases of uranium. First, a large quantity of molten uranium is handled during the melting and casting operation. Second, moderate quantities of divided uranium scrap, which can be more readily ignited than bulk pieces, can be stored outdoors under water in containers. Finally, large quantities of uranium in the form of depleted uranium munitions are stored by the military.

Up to about $700 \mathrm{~kg}$ of molten uranium could be poured during a casting operation. If an operational or equipment failure resulted in the release of

*This section prepared with the assistance of Dr. Jofu Mishima, Pacific Northwest Laboratories. 
the molten uranium and the loss of the inert gas cover, the uranium would oxidize rapidly and a fraction would be made airborne. Carter and Stewart (1970) experimentally measured the airborne release from molten uranium and measured airborne release rates ranging from $0.005 \%$ to $0.3 \%$ depending upon the conditions - ignition and burning, melting, or partial disruption of liquid into droplets.* The potential airborne release from this scenario range from $0.04 \mathrm{~kg}$ to $2 \mathrm{~kg}$ of uranium. Casting operations occur in enclosed facilities and some of the airborne material will be lost due to natural processes such as gravitational settling or deposition on surfaces during its transport to the release point from the facility. Many such facilities are equipped with particle removal devices such as filters which further reduce the emission.

Scrap metal such as turnings can be stored under water in metal cans. Prezbindowski (1983) analysed such an event postulated to occur outdoors.** $190 \mathrm{~kg}$ of uranium turnings in a 30 gallon metal drum were assumed to ignite and oxidize to completion. The airborne release was estimated to be $0.1 \%$ resulting in $0.190 \mathrm{~kg}$ being released to the environment.

The potentially most serious accident would involve a fire in a munitions storage bunker (igloo) holding a large quantity of various types of munitions (depleted uranium, high explosive, etc.). It is postulated that 12,000 rounds of a $105 \mathrm{~mm}$ depleted uranium cartridge could be present. Each cartridge would hold $3.3 \mathrm{~kg}$ of uranium resulting in a total of $40,000 \mathrm{~kg}$ of uranium. Other types of combustibles such as wooden crates and pallets, paper based packing materials, etc. would also be present. If the material present were ignited, the fire would initially spread slowly until sufficient flammable vapors could be generated and flashover occurs. Once flashover occurs, the entire contents of the enclosure are involved. The fire soon becomes oxygen limited due to the limited accessibility of air. Eventually, the cartridges themselves would be ignited and, if containment is lost, the fire would burn more vigorously due to the greater availability of oxygen.

Igloos are designed to vent in a perferred direction which does not involve adjacent structures. The flammable vapors released may well burn

\footnotetext{
${ }^{*} R$. F. Carter and K. Stewart, "On the Oxide Fume Formed by the Combustion of Plutonium and Uranium," Inhaled Particles III, Unwin Brothers Limited, The Gresham Press, England, 1970.

**D. L. Prezbindowski, "Uranium Oxide Facility Safety Analysis Report," UNI-M-157-DR, United Nuclear Industries, Richland, Washington, 1983.
} 
outside the facility due to the high vapor generation rate reducing radiant heat transfer to the materials inside.

There are two types of cartridges cases used for depleted uranium munitions metal and combustible. The depleted uranium portion of metal cased cartridges were ejected from and unaffected by the fire in a large-scale, outdoors test.* Depleted uranium from combustible-cased munitions in similar tests were not ejected from the fire and were almost completely oxidized ( $83 \%$ and $85.2 \%$ ). ** Collection and analysis of the residual material did not indicate a loss of uranium and air samples taken during part of the burning and a 11 of the recovery period did not show any significant airborne release.***

Experimental studies measured the rate of oxidation and airborne release during oxidation at elevated temperatures $(400 \mathrm{C}$ to $1200 \mathrm{C}$ ) of the depleted uranium portion of large-caliber munitions in air and a $50 \%$ air-50\% carbon dioxide mixture. The maximum airborne fractional release rate measured during the outdoor test using combustible materials as the heat source was $2.2 \times$ $10-6 / \mathrm{min}$ by weight. The material was primarily $U_{3} 0_{8}$. About $50 \%$ of the material had a by weight aerodynamic equivalent diameter of 10 microns or less. The three depleted uranium specimens oxidized an average of $44 \%$ during the three hour test. The velocity of air passing around the samples was $2.23 \mathrm{~m} / \mathrm{s}(5 \mathrm{mph})$. Similar but lower rates were measured in laboratory studies at various temperatures and atmospheres.

For the worst case accident involving depleted uranium it is postulated that $40,000 \mathrm{~kg}$ of depleted uranium are involved in an igloo fire and that it is completely oxidized. It is also assumed that the material is combustiblecased although the igloo limit is for metal-cased. Based upon the experimental studies reported by Elder and Tinkle, **** the material would be completely

${ }^{*}$ R. L. Gilchrist, G. B. Barker, and J. Mishima, "Radiological and Toxicological Assessment of an External Heat (Burn) Test of the $105 \mathrm{~mm}$ Cartridge, APFSDS-T, XM-774," PNL-2670, Pacific Northwest Laboratory, Richland, Washington, 1978.

${ }^{*}$ C. D. Hooker et al, "Hazards Classification Test of the Cartridge, $120 \mathrm{~mm}$, APFSDS-T, XM-829," PNL-4459, Pacific Northwest Laboratory, Richland, Washington, 1983.

***J. C. Elder and M. C. Tinkle, "Oxidation of Depleted Uranium Penetrators and Aerosol Dispersion at High Temperatures," LA-8610-MS, Los Alamos Scientific Laboratory, Los Alamos, NM, 1980.

****J. C. Elder and M. C. Tinkle, "Oxidation of Depleted Uranium Penetrators and Aerosol Dispersion at High Temperatures," LA-8610-MS, Los Alamos Scientific Laboratory, Los Alamos, NM, 1980. 
oxidized in $400 \mathrm{~min}$. At the rate of $2.2 \times 10^{-6} / \mathrm{min}, 35 \mathrm{~kg}$ would be made airborne of which half are respirable particles. The total airborne release of respirable depleted uranium thus would be $18 \mathrm{~kg}$.

\subsubsection{Calculations of Doses}

The effective dose equivalent for an $18 \mathrm{~kg}$ release of depleted uranium was calculated to be in the range from 0.001 to 0.06 rem. Heavy metal poisoning of the kidneys is not a factor because the uranium would not be in soluble form.

\subsubsection{Implications for Emergency Preparedness}

No special offsite emergency preparedness is necessary for depleted uranium products because doses are below protective action guides.

\subsection{Summary of Facilities to be Covered}

Fuel Cycle: The accident with the greatest potential hazard appears to be release of a large quantity of $U_{6}$. The release of a large quantity of $U_{6}$ presents a chemical toxicity hazard. The greatest potential hazard is at $\mathrm{UF}_{6}$ conversion plants where hot 14-ton cylinders are handled outside. NRC licenses two such plants. The rupture of a hot cylinder is quite plausible and could lead to multi-ton releases of $U_{6}$. The release would begin instantly. In such a case evacuation to several kilometers downwind would be appropriate for very calm weather conditions. The plume is easily detectable by sight and by smell at levels well below levels likely to cause injury. Thus people downwind would be able to see the plume coming and would be able to judge for themselves when they have reached an area of safety.

In an actual accident the release could be greatly diminished by spraying the release point with water or carbon dioxide. This is probably the most effective action that can be taken to mitigate offsite consequences.

The release of low-enriched $U_{6}$ could also occur from smaller 10-ton cylinders and could occur inside a building, which would prevent escape of much uranium. For the 9 such facilities licensed by NRC the appropriate response would be similar to that above but would be limited to distances of perhaps about half as great. 
The release of high-enriched $U F_{6}$ from hot cylinders may not require offsite response due to the small cylinder size used.

The release of $U_{6}$ from cold cylinders does not require a response because the quantities released would be quite small. With regard to the heating of cold cylinders in a fire and subsequent release, a response similar to that for hot cylinders may be appropriate, but additional warning time would generally be available.

For a criticality accident, the lower end of the protective action guide range could be exceeded for a person standing outside on the plume centerline out to a distance of about 250 meters from the release point assuming adverse weather conditions. The calculated doses are based on the assumption of a pulsating criticality lasting 8 hours and the person standing outside on the plume centerline for the entire 8 hours. Three additional licensees might be in this category.

An appropriate emergency response to a criticality accident during adverse meteorology would be immediate sheltering and closing windows up to a distance of 250 meters downwind. This response should be accomplished within about 3 or 4 minutes after the criticality occurs. The initial pulse is likely to be the largest one. Plume travel time to 250 meters would be about 4 minutes for low wind speeds and 1 minute for average wind speeds. There would be some added delay due to holdup in the liquid solution and the building atmosphere. After the immediate sheltering response, evacuation could be considered as an alternative to further sheltering.

Preparedness for such a response is recommended for the area within 200 to 250 meters from high-enriched uranium and plutonium processing.

Plutonium facilities (none currently operating) may also need special offsite emergency preparedness due to airborne releases of plutonium. However, the GESMO analysis discussed in Section 2.2.6 would indicate that extensive preparedness may not be appropriate.

Byproduct material and plutonium licensees: A total of about 48 Part 30 or Part 70 licensees were identified who were authorized to possess one or more radionuclides in unsealed form in excess of the quantities in Table 13 of this analysis (i.e., effective dose equivalent could exceed 1 rem offsite or thyroid dose could exceed 5 rems). However, some of the licensees have little or no need to possess as much as they are authorized to and some can do an evaluation to show releases would be smaller than assumed. We estimate that 
most of the licensees will elect to lower their authorized possession limits or perform an evaluation rather than submit a plan. Thus, the total number of affected licensees is likely to be about 10 exceeding the limit for plutonium and 7 exceeding the limit for other materials, specifically Am-241, Po-210, $\mathrm{I}-125, \mathrm{I}-131, \mathrm{H}-3, \mathrm{P}-32, \mathrm{Sr}-90, \mathrm{Cm}-242$, and $\mathrm{Cm}-244$.

In all cases a fire would be the accident of concern. The appropriate emergency response would be to evacuate people from the immediate vicinity (at least 100 meters) so as not to interfere with firefighting and to shelter or evacuate everywhere else where smoke can be smelled. These actions should be taken within a few minutes.

\subsection{A Protective Action Strategy}

The most important characteristic of the accidents discussed is that there is likely to be little or no warning time before releases start. The most important accidents, $U_{6}$ releases and fires, are likely to be controlled within roughiy half an hour in a majority of cases. Thus releases are often likely to stop or be greatly reduced within a half hour.

\subsubsection{The Initial Response}

Quick decisions and prompt actions are necessary. The goal should be to make decisions on protective actions and start implementing those decisions within 5 or 10 minutes of discovering the accident.

The heart of an effective protective action strategy is quick protective action decisions because accidents of concern are likely to happen so quickly that decisions on protective actions must be immediate to be effective. Thus, the licensee's initial notification of police and fire officials should include a recommendation on what protective actions are appropriate and the distances to which the protective actions are appropriate. This can only be done if the licensee has thought in advance about what he would recommend. 
The appropriate protective actions for an airborne release are: (1) sheltering in buildings with the windows closed, and (2) leaving the immediate vicinity. Sheltering with windows closed should provide, on the average, roughly a factor of three protection against the inhalation of radioactive materials. Inhalation is the dominant exposure pathway for all the radioactive materials of concern. A factor of three protection will result in a substantial dose reduction and will meet the EPA's objective of reducing dose for those people who would receive doses exceeding the protective action guides. Ad hoc respiratory protection could reduce exposures by an additional factor of three. Ad hoc respiratory protection means breathing through cloth such as a towel, a crumpled handkerchief, a bed sheet, or a blanket.

Leaving the vicinity can result in the complete elimination of exposure if it can be done before the release starts. The later the movement starts, the less the benefit. This action should not be confused with evacuation to great distances. The movement could be as 1 ittle as 50 or 100 yards in a cross wind direction to get out of the direct downwind plume.

In general, the licensee should recommend both sheltering and leaving the vicinity to the offsite response organization responsible for public health and safety. Both are suitable options that meet the EPA's protective action objectives. The decision on which to use should be left to the offsite response organization. The offsite response organization would then make its decision on what to do based on the practicality of the actions at the particular time and place of the accident. In many instances a combination of the two protective actions may be appropriate, for example, moving spectators out of the areas and sheltering nearby residents in their homes.

The next question is, what areas should be involved? The first considerations are common sense and practicality. The recommendation should be that people should move out of dense smoke or fumes, either by leaving the vicinity or sheltering indoors. The areas and actions involved should to a large extent be determined by practicality. Simply put, what is it practical to do in a very short time?

But to what distances are actions appropriate? We suggest distances below, but again practicality should be considered. If protective actions can be taken over larger areas than suggested, it would be appropriate to take those actions. Conversely, if there were not enough time to take actions for 
the entire distance, then the area where actions would be taken could be reduced until it was small enough to handle in the time available.

It is also possible that the emergency would occur so quickly that no protective actions could be taken. This possibility is inherent in any type of emergency response. The emergency plan and emergency response capability do not guarantee any particular outcome will be achieved. They merely assure that people will act quickly and efficiently to do whatever they can reasonably do to help.

Appropriate action distances are suggested below, keeping practicality in mind. It is considered impractical to base distances on measurements of source terms and meteorological conditions. There would not be nearly enough time, nor is such assumed precision necessary or appropriate.

Thus, we will base estimated distances on assumed releases. It would not be practical or appropriate to assume a very-worst case conservative release. The Commission's policy is that, "Emergency planning should be based on realistic assumptions regarding severe accidents."

For an accident involving a quantity or material 10 times the amount requiring a plan we recommend a response distance of about 100 meters.

The 100-meter distance is selected based on the following factors:

1. Isolation areas of this size are commonly used by emergency personnel.

2. Doses exceeding the lower end of the protective action guide range would generally not be exceeded beyond this distance for the largest plausible releases and average meteorology $(D, 4.5 \mathrm{~m} / \mathrm{s})$ or for adverse meteorology $(F, 1 \mathrm{~m} / \mathrm{s}$ ) with releases of more likely size (one-tenth the assumed maximums).

*U.S. Nuclear Regulatory Commission Policy and Planning Guidance - 1985," NUREG-0885, Issue 4, 1985, page 6. 
3. The upper end of the protective action guide range is unlikely to be exceeded beyond that distance even under very adverse but realistic circumstances (i.e., considering plume buoyancy, people not likely to remain in smoke, possible wind shifts, or other factors that may occur).

If the quantity of material involved in the accident is about 100 times the quantity requiring a plan the appropriate distance would be about 500 meters.

The 500-meter distance is selected based on the following factors:

1. A 500-meter distance is still a practical size area for providing a reasonable response.

2. A distance of 500 meters provides approximately a factor of 10 dilution in concentration compared to 100 meters. (See Figure 1 curves for $D$, $4.5 \mathrm{~m} / \mathrm{s}$ wind speed and $\mathrm{F}, 1 \mathrm{~m} / \mathrm{s}$ wind speed.)

3. For most accidents, the lower end of the protective action guide range would not be exceeded beyond that distance.

4. For worst-case accidents the upper end of the protective action guide range is unlikely to be exceeded under realistic circumstances.

Using similar logic, the distance appropriate for accidents involving 500 times the quantity needing a plan would be about 1500 meters, or about a mile. In no situations would distances beyond one-mile be recommended for action because actions over larger areas would be too difficult to undertake within the time available.

The same type of considerations could be applied to $U_{6}$ releases. For less than $50 \mathrm{~kg}$ of $\mathrm{UF}_{6}$ at risk a distance of 100 meters would be appropriate. For $500 \mathrm{~kg}$ of $\mathrm{UF}_{6}$ at risk a distance of 500 meters would be appropriate, and for a 14-ton cylinder, one mile would be an appropriate distance.

We have intentionally not defined an emergency planning zone for either the plume exposure pathway or the ingestion pathway as is done for nuclear power plant emergency planning. 
The purpose of the planning zone for nuclear power plants is to identify a jurisdictional area in which emergency response organizations should be involved in the planning. For fuel cycle and other radioactive material licensees, the response would be under the direction of the local fire and police departments just as similar industrial accidents are handled. It is only necessary to identify the organizations that will be notified and will respond rather than a geographical area for which planning would take place.

\subsubsection{Locating Contamination}

After the release has ended, it would be necessary to begin radiation surveys to locate contamination offsite. The primary responsibility for these surveys rests with the State radiological protection department. The State, at its request, can obtain technical support from the U.S. Department of Energy, which has radiological assessment teams that can be called to the site.

However, since the licensee initially is likely to have the only trained personnel equipped with radiation detection instruments it would be expected that they would initially make measurements in an attempt to provide an early estimate on the degree of contamination.

\subsubsection{The Assessment Phase}

Soon after the release has ended, usually within half an hour to an hour, the assessment phase of the emergency response should begin. The public will be concerned about whether the danger is over, whether they were exposed, whether they are contaminated with radioactivity, whe her their homes are contaminated with radioactivity, and what should they do. The news media will want to know what happened. Both the licensee and the NRC must be prepared to respond to such concerns promptly or suffer damaged reputations, ill-will, and possibly lawsuits.

As discussed above, field measurements to locate ground contamination will be underway. 
The question of whether people were exposed can only be answered with abundant field measurements. Generally, direct measurements of radioactive material concentrations in the plume will not be possible because of a lack of time to prepare and a lack of ability to locate and follow the plume. Nevertheless, plant personnel should attempt such measurements with available instrumentation to the extent possible because if they are fortunate enough to get data, the data will be valuable.

The answers of whether or to what degree people were exposed are likely to be best answered by measurements of ground contamination and bioassay measurements. Ground contamination measurements will allow a direct determination of whether there was a release. They will also allow a quick rough order-ofmagnitude estimates of the time-integrated exposure to people in the areas.

In addition, the "Emergency Planning and Community Right-to-Know Act of 1986" requires that releases of radioactive materials in excess of certain quantities must be immediately reported to the National Response Center. Quantities requiring an immediate report were proposed in the Federal Register (52 FR 8172) on March 16, 1987 . As soon as the licensee knows that a reportable quantity has been released, an immediate notification of the National Response Center is required. Failure to comply could result in a fine of up to $\$ 25,000$ and jail if the failure were willful.

\section{VALUE/IMPACT}

\subsection{Alternatives}

Three alternatives have been identified: (1) adopting a regulation containing the proposed requirements, (2) imposing the requirements by license condition rather than by regulation, and (3) imposed no new requirements with regard to emergency planning. The first two alternatives would have essentially the same value and costs. Those values and costs are discussed below. The third alternative, no new requirements, would have essentially no value or costs. 


\subsection{Value of the Proposed Action}

Value can be expressed in terms of risk reduction.

Consider a release in which the effective dose equivalent at a distance of 100 meters is 5 rems, assuming Class $F$ atmosphere stability and a wind speed of 1 meter/sec. The area over which the 1 rem protective action guide would be exceeded would be 0.006 square miles. If this area contained people at the average population density of the continental United States (72 people/square mile) it would contain on the average about half a person.

However, the facilities under consideration are usually located in built-up areas. A survey of potentially affected licensees shows that typical population densities are about 3,000 people/square mile.* Thus perhaps about 20 people would typically be in the area. Generally about $80 \%$ of people are in the buildings so about 4 people would be outdoors and 16 would be indoors.

The average dose to a person outdoors in the area was calculated to be about 3 rems. (This value was calculated for an open field; doses in urban areas would be less, but we ignore that factor.) In addition, doses to people in buildings would be half this dose because of protection provided by the building.

The total collective dose for the urban area thus might be 40 person-rems. Protective actions that would be available to these people are primarily evacuation and sheltering. Evacuation would be the more effective if it could be done promptly before the plume arrived. Sheltering would often be more practical because it can be done faster and most people are already inside.

Very roughly the dose savings, due to protective actions for this adverse meteorology could be put at 20 person-rem, about half the potential dose. Assuming that the chance of death due to cancer due to doses of several rems is in the range between zero to $10^{-4}$ cancer deaths/rem. The expected number of lives saved due to the protective actions would be less than 0.002 for adverse meteorology and roughly 0.00002 lives averaged over all meteorology.

*J. P. McBride, "Economic Consequences of Accidental Releases from Fuel Fabrication and Radioisotope Processing Plants," NUREG/CR-0222, 1979, Appendix A. 
Our estimate of the frequency of a major release is less than 10-4/year. Insurance statistics available from insurance companies dealing in commercial structures indicate fire losses in unsprinklered commercial and industrial facilities to be $0.006 /$ year. Sprinkler failure rates are estimated to be 0.038 should a fire occur. ${ }^{* *}$ The fire loss rate for a sprinklered facility should thus be roughly $2 \times 10^{-4} /$ year. It is now assumed that additional site specific factors will reduce the probability of a release to roughly 10-4/year. Examples of such factors would be: material kept in fireproof storage thus preventing significant release, filter system does not fail thus preventing release, or firemen extinguish fire before radioactive material is heated hot enough for a significant release, and many more. Thus protective actions could be expected to save 0.00000002 lives per year per facility.

If a life is given a value of ten-million dollars, the value of protective actions at a typical site in an urban area is $\$ 0.20$ per facility per year or less.

Now consider a release in which the effective dose equivalent at a distance of 1000 meters is 5 rems assuming Class $F$ atmospheric stability and wind speed of 1 meter/sec. At this level early injuries have still been avoided. The area over which the 1 rem protective action guide would be exceeded would be 0.15 square miles. For a typical built up site this area would contain about 450 people.

The average dose to a person outdoors in the area was calculated to be about 3 rems and to a person indoors was calculated to be 1.5 rems. The total collective dose assuming some people are indoors as previously discussed might be 800 person-rem. The dose savings due to protective actions could be about half of this or 400 person-rem. Lives saved due to these protective actions could be up to 0.04 life for adverse meteorology and 0.04 ife for average meteorology.

With the frequency of a major release at 10-4/year, protective actions might perhaps save up to 0.000004 life per year per facility.

\footnotetext{
**National Fire Protection Association, Fire Protection Handbook, 14th edition, Table 14-19, page 14-5.
} 
If a life is given a value of ten-million dollars, the value of protective actions in a densely populated urban area is $\$ 4$ or less per facility per year.

\subsection{Cost}

For the smaller class of accidents, those exceeding 1 rem offsite but not 5 rems at 1000 meters, the 1 icensee is considered to have a 50-page plan telling what he would do in the event of emergencies such as fires.

Cost data were obtained from two radiopharmaceutical manufacturers. Both licensees calculated the cost of the onsite contingency plans required by order. The manufacturer with a small program and limited facilities estimated the initial set-up cost $\$ 84,000$. Annual operating costs were estimated to be $\$ 18,000$. Labor accounted for $1 / 2$ to $2 / 3$ of the cost in each category. Labor was given a value of $\$ 30 /$ hour with no overhead charged. The main equipment costs were for radios, extra monitoring equipment for emergency use, and extra respirators. The largest annual expense is for training. Other operating expenses are for audits, drills, and equipment replacement and maintenance.

To place all expenses on an annual basis the initial set-up cost was divided by 10, assuming a ten-year useful life of a plan. Thus annual costs are estimated to be $\$ 26,000 /$ year/facility for this radiopharmaceutical manufacturer with a small program.

A second radiopharmaceutical manufacturer with one of the largest programs that would be covered by the regulation reported that the cost of establishing their on-site radiological contingency plan was more than $\$ 550,000$. No annual operating costs were given.

Assuming a 10-year plan life and operating costs of $\$ 18,000 /$ year (the estimate of the other manufacturer) the total annual cost is $\$ 73,000 /$ year/ facility for large facilities.

Costs to NRC to review and inspect plans have been estimated to be $\$ 4,000 /$ year/facility.

\subsection{Value/Impact of Alternatives}

The costs of emergency preparedness are expected to exceed the benefits in terms of protecting public health and safety as shown below. 
Table 19. Comparison of Costs and Benefits of Special Emergency Preparedness

\begin{tabular}{lll}
\hline Size of Licensee & Cost & Benefit \\
\hline Smal1 - Possessing 5 times quantity in Table 13 & $\$ 30,000 / \mathrm{yr}$ & $\$ 0.20 / \mathrm{yr}$ \\
Large - Possessing 50 times quantity in Table 13 & $\$ 77,000 / \mathrm{yr}$ & $\$ 4 / \mathrm{yr}$ \\
\hline
\end{tabular}

\subsection{STATUTORY CONSIDERATIONS}

\subsection{NRC Regulatory Authority}

The Atomic Energy Act gives NRC authority to adopt regulations for protecting public health and safety. This proposed rule would be justified under that authority.

\subsection{Agreement State}

The question is whether NRC's Agreement States would adopt offsite emergency preparedness requirements similar to NRC's.

The NRC's Office of State Programs intends to make this requirement a matter requiring compatability. Thus, NRC would require that Agreement States adopt requirements similar to NRC's.

\subsection{Environmental Impact Appraisal}

The NRC's regulations [10 CFR $\S 51.5(\mathrm{~b})$ ] require that substantive and significant amendments (from the standpoint of environmental impact) of regulations require an environmental impact statement.

To make the finding that amendments are not substantive and significant from the standpoint of environmental impact, NRC regulations [10 CFR § 51.5(c)(1)] require the preparation of a negative declaration and an environmental impact appraisal.

The environmental impact appraisal must include [10 CFR $\$ 51.7(\mathrm{~b})]$ :

(1) A description of the proposed action. 
(2) A summary description of the probable impacts of the proposed action on the environment.

(3) The basis for the conclusion that no environmental impact statement need be prepared.

The proposed action is a rule to require emergency procedures for offsite releases. A description of the proposed requirements is contained in Section 1.1, "Description of the Proposed Action."

A summary description of the probable impacts of the proposed action on the environment is contained in Section 3.2, "Value of the Proposed Action."

The basis for the conclusion that no environmental impact statement need be prepared is that the benefits to public safety are neither substantive nor significant as described in Section 3.2, "Value of the Proposed Action," and summarized in Table 24.

\section{CONCLUSIONS}

The conclusion of this Regulatory Analysis is that accidents at fuel cycle and other radioactive material licensees pose a very small risk to the public. Serious accidents are infrequent and would generally involve relatively small radiation doses to few people located in small areas.

This is not to say that radiation doses large enough to exceed guides for taking protective actions cannot occur. It may be possible to have an accident at some licensed facilities which would cause offsite doses exceeding protective action guides. However, offsite radiation doses large enough to cause an acute fatality or even early injury from an airborne release are not considered plausible.

For a licensee possessing 5 times the amount of material in Table 13, we conclude that protective actions in an urban area might save up to 0.00000002 lives per year per facility. Perhaps about 20 to 30 licensees have a possibil$i$ ty of such an accident or worse. For these facilities we recommend there should be notification of local authorities. However, no special facilities, equipment, or other resources for responding are considered necessary. 
For a licensee with 50 times as much releasable material as in Table 13, we conclude that protective actions in a built up area might save up to 0.0000004 lives per year per facility. There may be 2 or 3 licensees with a capability of an accident this severe.

The cost of this preparedness may not be justified in terms of protecting public health and safety. Rather we would justify it in terms of the intangible benefit of being able to reassure the public that if an accident happens local authorities will be notified so they make take appropriate actions.

Although emergency preparedness for fuel cycle and other radioactive material licensees cannot be shown to be cost effective, the NRC feels that such preparedness represents a prudent step which should be taken in line with the NRC's philosophy of defense-in-depth, to minimize the adverse effects which could result from a severe accident at one of its facilities. 


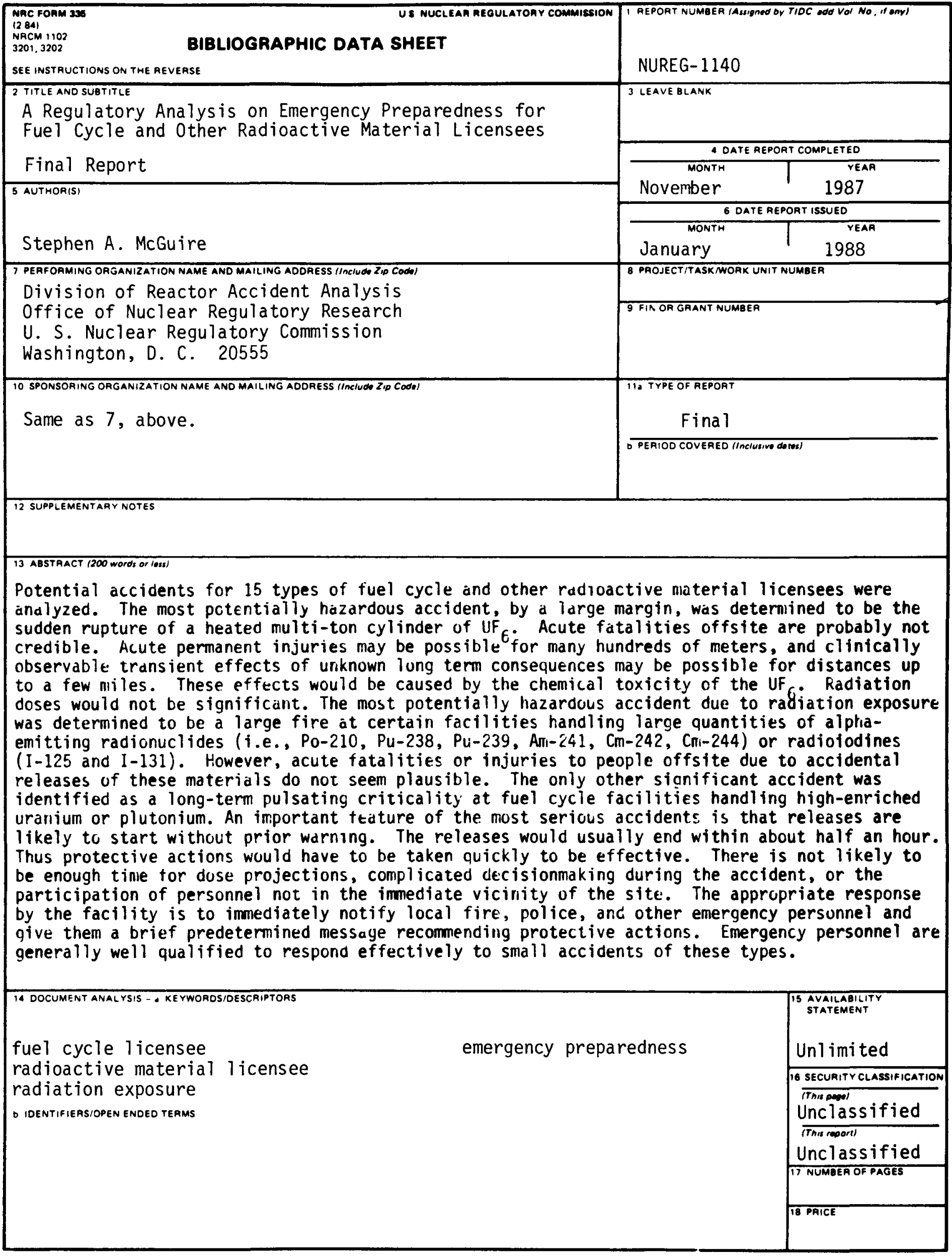

